\title{
TAXATION WITHOUT REALIZATION: A PROPOSAL FOR ACCRUAL TAXATION
}

\author{
David J. Shakow ${ }^{\dagger}$
}

\section{An Overview of Accrual Taxation}

For over ten years, debate about the proper structure of the tax system in the United States has focused on the consumption tax as a replacement for the income tax. ${ }^{1}$ While consumption tax advocates argue for fundamental changes in the tax law, ${ }^{2}$ the most seriously considered changes in the income tax system are merely incremental in nature. $^{3}$

† Associate Professor of Law, University of Pennsylvania Law School.

A number of persons were of substantial assistance to me while I was preparing this article. Dan Halperin originally interested me in the topic, and meticulously reviewed an early draft of the article. Hank Gutman has read and carefully commented on more than one of the drafts. I also received helpful comments from Al Warren and Regina Austin.

Alan Auerbach reviewed some of my conclusions from the economics perspective, and gave me direction in those areas that were less familiar to me. Elizabeth Fogler of the Flow of Funds Section of the Federal Reserve was a constant source of assistance in interpreting the Flow of Funds data and related sources.

The analysis of data that served as the basis for the discussion of liquidity in Section III of the paper was done for me by Michael Twisdale, who was serving as a Winston Fellow of the Institute for Law and Economics of the University of Pennsylvania. I also received assistance from Karen Wolfgang of the Class of 1985 at the University of Pennsylvania Law School. Financial assistance for this research was supplied by the University of Pennsylvania Law School, which also provided me with a personal computer that allowed me to make the computations that serve as the basis for the three appendices.

I take full responsibility for the errors that the persons mentioned could not eliminate from the paper.

1 The stimulus for this debate came from Professor Andrews' article, A Consumption-Type or Cash Flow Personal Income Tax, 87 HARv. L. REv. 1113 (1974). Professor Andrews, in turn, is trying to give a practical structure within the context of United States taxation to the proposals that can be found in N. KALDOR, AN ExPENDITURE TAX (1955).

2 See, e.g., Andrews, supra note 1, at 1113; Bradford, The Case for a Personal Consumption Tax, in What Should Be TAXED: INCOME OR EXPENDITURE? 75 (J. Pechman ed. 1980); Institute for Fiscal Studies, The Structure and Reform of Direct Taxation (1978) [hereinafter cited as Meade Committee Report]. For a much earlier call for restructuring income tax systems, see N. KALDOR, supra note 1.

3 See, e.g., Graetz, The 1982 Minimum Tax Amendments as a First Step in the Transition to a Flat Tax, 56 S. CAL. L. REv. 527, 551-54 (1983) (arguing that a flat tax proposal would be a logical extension of the 1982 minimum tax amendments); President's Tax Proposals to the Congress for Fairness, Growth, and SimPlicity (1985) [hereinafter President's TAX Proposals] (focusing primarily on the repeal of existing deductions). 
Even some supporters of a consumption tax might prefer to improve the income tax. Professor Kaldor, an important early advocate of the consumption tax, calls the consumption tax a "second best" solution that should be used to supplement the income tax because the defects in the income tax are not likely to be remedied. ${ }^{4}$ In his view, the introduction of a supplemental consumption tax would not remove the need to remedy the "anomalies and distortions" of the current income tax.

Professor Andrews, whose support for the consumption tax helped popularize it in this country, presents the problems that arise under the current income tax law very clearly:

If we think about the personal income tax in real terms, as a tax on . . . consumption plus accumulation . . ., reflection will show that its worst inequity, distortion, and complexity arise out of inconsistency in the treatment of accumulation. . . . Savings out of ordinary income are fully taxed, while accumulation of wealth in kind through appreciation in value of property already owned is not reflected in current taxable income. ... [Moreover], [s]ome gains, though realized, are unrecognized by reason of special statutory provisions like those governing corporate reorganizations. . . .

The way out of these difficulties, according to the accretion ideal, is to make taxable income provide a more comprehensive reflection of real accumulation . . . by including unrealized changes in the value of property in taxable income. Literal achievement of that goal would require that all assets be taken into account at current fair market value at the end of each accounting period. Although practical exigencies may prevent comprehensive inclusion of unrealized appreciation, improvement is thought to lie in that direction. ${ }^{\mathbf{B}}$

Professor Andrews goes on to present his solution to those problems: a consumption tax. He, like others who have joined this debate before and after him, advances his solution without fully consider-

- See Kaldor, Comments by Nicholas Kaldor, in What Should Be TAXEd: INCOME OR EXPENDITURE? 151, 153 (J. Pechman, ed. 1980) (commenting on Andrews, A Supplemental Personal Expenditure Tax, in id.).

Kaldor's fundamental problem with an income tax is that it taxes changes in the value of assets that stem from changes in interest rates. See Kaldor, id.

To the extent these changes in interest rates reflect the effects of inflation, they can be compensated for relatively easily under the proposal in this Article. See Part IV, infra. To the extent the changes in value are due to other causes, this Article takes the position that they ought to be taxed.

- Kaldor, id., at 154.

- Andrews, supra note 1, at 1113, 1115-16. 
ing a proposal that has resurfaced periodically in the last fifty years-an accrual tax system. Under such a system, taxpayers would account annually for all changes in the value of their assets. ${ }^{7}$ An accrual tax system offers many advantages; that is the reason the proposal never dies.

Unfortunately, the accrual system has never attracted a large group of adherents because its twin problems of valuation (How can all assets be valued every year?) ${ }^{8}$ and liquidity (How can taxpayers pay taxes if they do not sell their assets?) have never been solved. ${ }^{9}$ Even the

7 One major effect of an accrual system is to tax increases in the value of investment assets currently. For summaries of the arguments for and against the taxation of gains on investment assets generally, see L. Seltzer, The Nature and Tax TREaTment of Capital Gains and Losses 83-108 (1951); Blum, A Handy Summary of the Capital Gains Arguments, 35 TAXES 247 (1957).

8 Professor Bittker suggests that the complexities that would result from the elimination of the realization requirement (mainly in the increased cost of appraisal) would probably not approach the cost of administering the realization requirement. Bittker, Tax Reform and Tax Simplification, 29 U. Mrami L. Rev. 1, 3 (1974); see also M. David, Alternative Approaches to Capital Gains Taxation 215 n.6 (1968) (" "T T]here are an awful lot of assets that can be valued annually, and I am not sure you should throw out the opportunity to do that just because others can't [be valued].' ") (quoting from summary of conference floor discussion); Wetzler, Capital Gains and Losses, in Comprehensive Income Taxation 115, 161 (J. Pechman ed. 1977) ("For some assets, such as publicly traded securities, the valuation objection is surely weaker than for others, and it would seem worthwhile to consider whether the liquidity objection is really significant enough to preclude accrual taxation where it is administratively feasible."). Professor Shoup states that under a system of current accrual of gains and losses "the simplification achieved for the income tax law as a whole would of course be enormous." Shoup, The White Paper: Accrual Accounting for Capital Gains and Losses, 18 CAN. TAX J. 96, 97 (1970). Professor Shoup was director of research for a study in 1937 by the Twentieth Century Fund that concluded that all increases and decreases in values of capital assets should be recognized on an annual basis. See Twentieth Century Tax Fund, Inc., Facing the Tax Problem 47684 (1937) [hereinafter cited as TwENTIETH CENTURY Fund]. The study's conclusion, however, was subject to the rather significant caveat that the attendant administrative problems must be solved. See id. at 490 .

${ }^{8}$ Language in some early Supreme Court decisions suggests a third potential problem: the constitutionality of an accrual tax system. See, e.g., Eisner v. Macomber, 252 U.S. 189, 207 (1920) (Income is not taxable unless it is "a gain accruing to capital, not a growth or increment of value in the investment."); Gray v. Darlington, 82 U.S. (15 Wall.) 63, 66 (1872) ("Mere advance in value in no sense constitutes the gains, profits, or income specified by the statute."), quoted with approval in Lynch $v$. Turrish, 247 U.S. 221, 230 (1918).

More recent decisions of the Supreme Court have led commentators to conclude that the Constitution is probably not a serious impediment to an accrual system. See, e.g., M. Chirelstein, Federal Income Taxation $\$ 5.01$, at 69 (4th ed. 1985); J. Sneed, The Configurations of Gross Income 71 (1967); Bittker, Charitable Gifts of Income and the Internal Revenue Code: Another View, 65 HARv. L. REv. 1375, 1380 (1952); Stone, Back to Fundamentals: Another Version of the Stock Dividend Saga, 79 Colum. L. Rev. 898, 916-17 (1979); Surrey, The Supreme Court and the Federal Income Tax: Some Implications of the Recent Decisions, 35 ILL. L. REV. 779, 791 (1941); see also Tax Reform, 1969: Hearings Before the House Comm. on Ways and Means, 91st Cong., 1st Sess. 4308 (1969) ("We conclude that it is within the 
few advocates of an accrual tax system have never considered systematically how the proposal might be implemented in the real world.

This Article develops a specific proposal for an accrual income tax system that gives particular attention to the problems of valuation and liquidity. Such a specific proposal for an accrual income tax system will enable policymakers to determine whether an accrual tax system is a reasonable path for fundamental tax reform.

The intellectual basis for accrual taxation is the Haig-Simons definition of income as the sum of consumption and the change in value of property. ${ }^{10}$ Commentators often use this definition in analyzing and evaluating proposals under an income tax. ${ }^{11}$ Requiring taxpayers to accrue changes in asset values would bring our tax system much closer to one based on the Haig-Simons definition. In addition, the Haig-Simons definition suggests that the distinction between capital gains and losses and ordinary gains and losses should be eliminated. ${ }^{12}$ As a tax system nears the Haig-Simons ideal, its faults become those ascribed to an income tax system generally. ${ }^{13}$ Compared to our current income tax system, however, an accrual system would be more efficient, more equitable, and, in significant ways, simpler.

An accrual tax system would be more efficient because the current system's deviations from an ideal income tax encourage undesirable economic activity. Under the current method of taxing gains only on sale, taxpayers are "locked in" to appreciated assets, resulting in decreased liquidity in the marketplace. ${ }^{14}$ In addition, the rules that provide

power of Congress to declare that an increase in value of assets . . . is rightfully subject to tax as income.") (quoting Robert K. Knight, General Counsel for the Treasury Department). I have ignored the constitutional problem in this Article.

${ }^{10}$ See H. Simons, Personal. Income Taxation 50 (1938), quoted in $M$. Graetz, Federal Income Taxation 89 (1985) (successor edition); Haig, The Concept of Income, in The Federal InCOME TAX 1, 7 (1921), quoted in M. GraETz, supra..

"For use of the definition in basic studies of the income tax, see U.S. DEP'T OF THE TREASURY, Blueprints for Basic TAX REForm 2 (1977) [hereinafter cited as BluEPRINTs] (outlining a proposal for fundamental tax reform, but "not recommend[ing] taxation of gains as accrued"); MEADE CoMMITTEE REPORT, supra note 2, at 31-33; Shachar, The Importance of Considering Liabilities in Tax Transition, 98 Harv. L. Rev. 1842, 1853 (1985). See generally Bittker, A Comprehensive Tax Base As A Goal of Income Tax Reform, in A Comprehensive Income TaX Base? A Debate 7-9 (1968) [hereinafter B. BitTKer] (noting the popularity of this definition as a basis for a "'true' or rigorous comprehensive tax base").

12 See B. BITTKER, supra note 11 , at 43.

13 For example, any income tax system will have to confront the broad problem of defining income, see MEADE COMMITTEE REPORT, supra note 2, at 30, although some of the problems of measuring income, such as determining the appropriate rate of depreciation and adjusting for inflation, can be avoided through alternatives such as a consumption tax system. See Blueprints, supra note 11 , at 3 .

14 See Wetzler, supra note 8, at 135 ("The lock-in effect of capital gains taxation 
favorable treatment for certain corporate reorganizations, but not for other exchanges of corporate stock, encourage inefficient concentration of corporate activities. ${ }^{15}$

This argument does not deny that even an ideal income tax will create economic inefficiencies; any tax but a lump sum tax will. ${ }^{16}$ By coming closer to the ideal, however, an accrual system can reduce the extent to which the income tax, in practice, has such undesirable effects.

In addition to being more efficient, an accrual income tax system would be more equitable than the current system. Fairness dictates that a tax system not tax more severely someone who sells an appreciated asset than someone who chooses to hold it. Fairness also dictates that situations where tax liabilities depend on technicalities be minimized. For example, the tax liability of someone who receives ITT stock in exchange for an interest in the Hartford Insurance Company should not depend on extraneous matters relating to ITT's prior dealings in Hartford stock. ${ }^{17}$ Anomalies such as these disappear when the rules on recognition, with their myriad exceptions and special cases, are eliminated.

As for the goal of simplicity, it must be conceded that a proposal to tax persons on increases and decreases in the value of assets is far from an obvious choice for simplifying the tax law. Indeed, a collection of comments on the possibility of adopting such a proposal reads like an object lesson in unsimplifying the tax laws. ${ }^{18}$ On the other hand, those

refers to its tendency to cause investors to postpone sales of appreciated assets."). For a discussion of the economic significance of the lock-in effect, see id. at 138-40.

10 See A. Feld, Tax Policy and Corporate Concentration 81-103 (1982). Preliminary empirical studies suggest that the actual influence of tax treatment on corporate concentration may be less significant than previous theoretical discussions suggested. See M. Kramer, Mergers and Acquisitions: The Ungrateful Favored Child of the Tax Laws 11 (May 9, 1985) [unpublished manuscript on file with the University of Pennsylvania Law Review].

16 See R. Musgrave, The Theory of Public Finance 157 (1959). A lump sum tax is a tax that "meets the condition that the amount of tax does not depend upon any variable in the system." Id. at 143. A "head tax," under which each taxpayer pays the same amount to the government, is a common example. See id. at 142-43.

17 See Chapman v. Commissioner, 618 F.2d 856, 861 -62 (1st Gir. 1980) (tax-free treatment of stock-for-stock exchange denied because requirement that eighty percent control be obtained "solely" for voting stock not satisfied due to ITT's purchase of eight percent of the outstanding shares of Hartford for cash two years before).

18 See, e.g., General Tax Reform: Panel Discussions Before the House Comm. on Ways and Means, 93d Cong., 1st Sess. 285 (1973) (testimony of Professor Richard Musgrave) ("Obviously, . . . taxation of all current but unrealized gains on an annual accrual basis would be unmanageable."); Blum, supra note 7, at 254 ("While every so often somebody proposes that unrealized capital gains (and losses) be taken into account in computing income, there has always been an overwhelming sentiment against putting taxpayers and tax administrators to the additional work necessarily entailed."); 
who have favored exploring an accrual tax system have been impressed by the amount of simplification that such a proposal, coupled with elimination of the capital gain/ordinary income distinction, could produce. Professor Vickrey asserts that his proposal for lifetime averaging of income, which shares the goal of reducing the significance of timing issues under the income tax, would have eliminated about half of the income tax provisions of the Internal Revenue Code as it stood fifteen years ago. ${ }^{19}$

The reason accrual taxation would simplify the tax system is fairly apparent once one begins paging through the Code. ${ }^{20}$ All of the provisions on ordinary gain and loss and on capital gain and loss would vanish, as would virtually all of the provisions relating to corporationshareholder relationships. ${ }^{21}$ Moreover, if accrual taxation applies to all assets (not just capital assets, for example), many details relating to capitalization, depreciation, and depletion might also be eliminated.

Meade CommitTee Report, supta note 2, at 129 ("Clearly the taxation of such [accrued] holding gains could put heavy strains on the cash position of closely owned businesses. . . . [F]or a wide range of assets this would be inordinately costly and difficult to implement."); Lowndes, Current Conceptions of Taxable Income, 25 OHIO ST. L.J. 151, 181 (1964) ("The administrative difficulties in connection with such a plan are so great that it is unlikely that Congress will ever adopt it."); Maguire, Book Review, 38 Colum. L. Rev. 710, 714 n.18 (1938) (reviewing Twentieth Century FuND, supra note 8) ("[Accrual taxation] might do a great deal to end unemployment, but hardly qualifies as a practical method of administering an income tax."); Wetzler, supra note 8, at 120 ("Completely eliminating deferral means taxing on accrual, which must be ruled out because it would be extraordinarily difficult to value nonmarketable assets every year in order to measure the accrued gain or loss."); see also Bradford, supra note 2 , at 83 :

Though it might be possible to measure these accruals currently where active markets exist, . . . such procedures have not interested practical men (in part because they do not seem to consider genuine the wide swings in wealth that these valuations imply). . . . The difficulty of obtaining annual valuations and the potential cash flow problems for taxpayers with large accrued income but no cash income have generally led to the acceptance . . . of a realization basis for capital gains accounting.

19 See Vickrey, Tax Simplification Through Cumulative Averaging, 34 LAw \& Contemp. Probs. 736, 742-44 (1969). Professor Shoup reached a similar conclusion. See Shoup, supra note 8 , at 97.

20 Professor Shoup outlines some of the provisions that would be deleted or reduced through accrual accounting for capital gains and losses. See Shoup, supra note 8, at 102. The Code provisions that could be eliminated or shortened by reducing the significance of timing issues (also a focus of the present proposal) are outlined by Professor Vickrey. See Vickrey, supra note 19, at 743-44 tables 1, 2.

${ }^{21}$ Indeed, one could consider eliminating the corporate tax structure completely. See infra text accompanying notes 77-95 (an accrual system would tax corporate shareholders directly on changes in value of their stock). Eliminating the corporate tax was part of a proposal advanced by the Twentieth Century Fund in 1937. See TwENTIETH CENTURY FUND, supra note 8, at 483; see also Shoup, supra note 8, at 100 (discussing how accrual accounting of gains could lead to repeal or reduction of corporate income tax). 
Perhaps even more significantly, eliminating the realization requirement would sharply reduce the opportunities for tax planning in business transactions, substantially simplifying the true costs of applying the tax laws.

A review of a number of cases decided by the Tax Court provides another useful measure of the extent to which the proposal developed in this Article would simplify the Code. ${ }^{22}$ Of the forty-six cases in volume 81 of the Tax Court Reporter that deal with substantive issues under the income tax,$^{23}$ the proposal would totally moot $\operatorname{six}^{24}$ remove substantial issues in three others, ${ }^{25}$ and reduce in importance the issues in six others. ${ }^{28}$ Thus, under this proposal about $30 \%$ of the cases reported in volume 81 that deal with substantive issues of income tax law

${ }^{22}$ This method of sampling has been used before to measure simplification in the area of complex transactions. See Hickman, Capital Gains and Simplification, in FEDERAL InCome TaX Simplification 223, 234-35 (C. Gustafson ed. 1979).

${ }^{23}$ There are 64 cases reported in volume 81 . Nine involve the estate tax, and two involve Social Security and self-employment taxes. Of the remaining 53 cases, seven are procedural or administrative in nature.

24 These cases involved the distinction between capital gain and ordinary income, see Foote v. Commissioner, 81 T.C. 930 (1983), aff d mem., 751 F.2d 1257 (5th Cir. 1985); Georgia Int'l Life Ins. Co. v. Commissioner, 81 T.C. 166 (1983); like-kind exchanges, see Bolker v. Commissioner, 81 T.C. 782 (1983), aff'd, 760 F.2d 1039 (9th Cir. 1985); Magneson v. Commissioner, 81 T.C. 767 (1983), affd, 753 F.2d 1490 (9th Cir. 1985); the year property was abandoned, see Daily v. Commissioner, 81 T.C. 161 (1983), affd mem., 742 F.2d 1461 (9th Cir. 1984); and LIFO inventories, see W.C. \& A.N. Miller Dev. Co. v. Commissioner, 81 T.C. 619 (1983).

${ }^{25}$ One involved the useful life of land, see Vecker v. Commissioner, 81 T.C. 983 (1983), aff d, 766 F.2d 909 (5th Cir. 1985); one involved a sale, see Vaughn v. Commissioner, 81 T.C. 893 (1983), and the third involved the transfer of a debt instrument, see American Air Filter Co. v. Commissioner, 81 T.C. 709 (1983).

28 One case involved the accumulated earnings tax, which may well be eliminated under the proposal. See Rutter v. Commissioner, 81 T.C. 937 (1983). Two involved pension arrangements, which will have little or no tax advantage under the proposal. See Anthes v. Commissioner, 81 T.C. 1 (1983), affd mem., 740 F.2d 953 (1st Cir. 1984); Efco Tool Co. v. Commissioner, 81 T.C. 976 (1983). Three others involved tax shelters depending on accelerated deductions, which will be reduced or eliminated under the proposal. See Rice's Toyota World, Inc. v. Commissioner, 81 T.C. 184 (1983), modified, 752 F.2d 89 (4th Cir. 1985); Surloff v. Commissioner, 81 T.C. 210 (1983); Elkins v. Commissioner, 81 T.C. 669 (1983). Two other cases that might have their significance reduced under the proposal involved the taxation of life insurance companies, which may be simplified once holders of life insurance are taxed directly. See National States Ins. Co. v. Commissioner, 81 T.C. 325 (1983), affd, 758 F.2d 1277 (8th Cir. 1985); Union Fire Ins. Co. v. Commissioner, 81 T.C. 368 (1983), affd, 768 F.2d 164 (7th Cir. 1985); $c f .2$ U.S. DeP'T OF THE TREASURY, TAX REFORM FOR Fairness, Simplicity and Economic Growth 268-71 (1984), reprinted in 53 STAND. FED. 'TAX REP. (extra edition) (CCH) 254-57 (Dec. 6, 1984) [hereinafter cited as TREASURY PROPOSALS] (discussing proposed changes in the taxation of life insurance companies in light of changes in the taxation of their products). Finally, two cases reported in volume 81 involved the maximum tax, which the Code no longer includes. See Van Kalker v. Commissioner, 81 T.C. 91 (1983), rev'd, 84-2 U.S. Tax Cas. (CCH) 9,727 (7th Cir. 1984); Doty v. Commissioner, 81 T.C. 652 (1983). 
would become moot or would be substantially reduced in their scope. ${ }^{27}$

As stated above, the two major obstacles to accrual taxation are the difficulty of valuing assets on an annual basis and the liquidity problems resulting from levying a substantial tax on persons who may hold few liquid assets. This Article discusses the valuation problem in Part II, which attempts to fit the accrual system to each category of assets that taxpayers may own. The Article then considers the liquidity problem in Part III by examining actual asset holdings of individuals. Next, Part IV discusses another benefit that may result from going to an accrual system: the ease of incorporating a full offset for inflation in such a system. Finally, Part V addresses the transition problems that might arise in switching from our current system to an accrual system.

\section{The Valuation of Assets Under an Accrual System}

An accrual tax system cannot succeed without a satisfactory method of valuing assets. This section considers how to value the major categories of assets.

At the outset, it should be recognized that the accrual system would mitigate the valuation problem in two ways. First, the expanded tax base allows for a lowering of tax rates, thus reducing the tax effect of each valuation. Second, a mistake in valuation in one year can be largely offset by a later correct valuation. The net effect of an incorrect valuation will be to shift income from one year to another. ${ }^{28}$

More importantly, in addressing the valuation problem, this proposal aims for improvement, not perfection, of the tax system. If the proposal abandons pure accrual in some cases, it should still be counted as a success if it creates a better system than current law. Of course, to justify a major change, the new system should be appreciably better than current law. ${ }^{2 \theta}$ Accordingly, the new system will leave an imperfect part of current law in place if it cannot be easily improved, as long as changes incorporated into the new system do not magnify the current imperfections. In particular, the proposal takes seriously the need to make the system administratively feasible.

The basic outline of the proposal is as follows:

${ }^{27}$ Of course, some of the simplification thus achieved would be offset by an increase in disputes over valuation.

${ }^{28}$ For example, if a property is worth $\$ 100,000$ in Year $1, \$ 110,000$ in Year 2, and $\$ 120,0000$ in Year 3, the effect of valuing it at $\$ 120,000$ in Year 2, with correct valuations in the other years, is to shift $\$ 10,000$ of income from Year 3 to Year 2.

${ }_{29}$ The Meade Committee noted that the existence of transition problems might support the conclusion that "an old tax is a good tax." See MEade CommitTeE REPORT, supra note 2 , at 22-23. 
1. General Accrual Rule. Taxpayers will value all assets and liabilities annually, recognizing gains and losses for tax purposes regardless of realization.

2. Capital Gains. The tax system will draw no distinction between capital gains and losses and other gains and losses. 3. Assets Excluded from Accrual Treatment. Recognition of gain on the sale of personal residences and consumer durables (including collectibles) and recognition of the gain or loss on the sale of the stock of certain closely held corporations and other assets that are particularly hard to value will be based on a modified version of the recognition rules of current law. Recognized gains and losses on most such assets, however, must be adjusted to take account of deferral. 4. Liabilities Excluded from Accrual Taxation. Increases and decreases in the value of consumer debt (including home mortgages) will be ignored.

5. Pension Funds. Pension funds will be taxed directly; no attempt will be made to attribute the gains in a fund to particular taxpayers.

6. Business Assets. In applying accrual taxation to business assets the system will in general use mechanical tests such as those used now for depreciation. The system will tax intangibles, such as good will, only on realization.

7. Bequeathed Assets. Gains and losses on all assets (including those that are not normally valued annually under the accrual system) will be recognized at death.

8. Liquidity Problems. Under restricted conditions, taxpayers with liquidity problems could defer their tax payments.

Two of the rules above that are not central to the concerns of this Article should be noted with a little more detail at this point. Abolishing the distinction between ordinary income and capital gains is a common aspect of proposals for accrual taxation and for change in the income tax system generally. ${ }^{30}$ Although abolishing this distinction would certainly simplify the operation of the tax system, its effects are not nearly as significant as a move to accrual taxation. For example, a review of the cases in volume 81 of the Tax Court Reporter shows that only two of the cases decided in that volume would be mooted if the

so See, e.g., Commission to Revise the Tax Structure, Reforming the Federal Tax Structure 37 (1973) [hereinafter cited as Commission to ReviSe]; H.R. REP. No. 3838, 99th Cong., 2d Sess. § 401 (1986) (Senate version of the Tax Reform Act of 1986, repealing deduction for a portion of long term capital gains). 
distinction were eliminated. ${ }^{31}$ This contrasts with the four other cases mooted by the accrual tax proposal, the three cases in which substantial issues were eliminated, and the six cases in which the importance of issues was substantially reduced. ${ }^{32}$

A provision for gains at death is an appropriate aspect of an accrual system. Most assets will be taxed on the basis of an annual valuation, and there is little reason to exempt from income tax whatever gain accrues in the year of death. The assets that are not included in the normal accrual system are exempted because valuing them annually would be too burdensome. However, Congress has been willing to require that all assets be valued for purposes of the estate tax. If this onetime valuation can be tolerated for purposes of the estate tax, it should be required for purposes of the income tax also. ${ }^{33}$

\section{A. Assets Excluded from the Annual Valuation Requirement}

It should be conceded at the start that a practical system for accrual taxation should not require valuation of every asset owned by every taxpayer. Assets of small value, for example, are best left outside a system of annual valuation if they are difficult to value. An advocate of accrual taxation must therefore confront the question of how such assets should be treated before considering how to value the various categories of other assets.

A number of alternatives are available for assets that are impractical to value on an annual basis. First, the system can treat these assets under the rules of current law, with gains and losses taken into account only on recognition. Second, the system could require taxpayers to value these assets less frequently than once a year. The system could then require taxpayers either to pay tax on the measured gain or loss or to adjust it for the period of deferral. Third, the government could determine the average change in value of assets similar to these assets. The system would then apply the average change to taxpayers' specific assets and treat these adjustments like any changes in value under the regular accrual system until such taxpayers made final adjustments when they sold the assets. Finally, the system could treat these assets under the recognition rules of current law but require adjustment of

s1 See supra note 24.

32 See supra notes 24-26.

ss Of course, since many estates are currently exempt from the estate tax, this proposal would increase the number of estates which must value assets. The point in the text is not that the appraisal of assets will, in all cases, be made in any event for purposes of the estate tax, but rather that valuing assets is considered an appropriate activity for an estate. 
recognized gains-to account for the advantage of deferral-and adjustment of recognized losses-to account for the disadvantage of deferral. While it is not necessary to choose one method for all assets excluded from normal accrual valuation, a single uniform exception would make it easier for taxpayers to apply the system as a whole.

\section{Current Law Treatment}

If the tax law treats some assets under the current rules, while it treats most others under the accrual system, taxpayers may be encouraged to invest inefficiently in assets receiving current law treatment in order to continue to reap the benefits of deferral. ${ }^{34}$ The seriousness of this problem depends on the magnitude and substitutability of the assets involved..$^{35}$ In general, tax policymakers should be concerned about distorting taxpayers' economic choices, and any decision to exclude assets from the accrual system must address that concern.

\section{Less Frequent Valuation}

This alternative has been proposed in some earlier proposals for accrual taxation. ${ }^{36}$ Less frequent valuation reduces the problem of improperly inducing taxpayers to purchase assets excluded from the accrual system. Nevertheless, it does not eliminate the problem completely. Moreover, if we have decided that a particular asset is too difficult to value annually, it is presumably still quite burdensome to value it every three or five years. If valuation will occur less frequently than this, we might just as well wait for an actual disposition (or death) to impose a tax.

34 Consider two assets in which a taxpayer can invest. The assets are identical except for the fact that one is subject to accrual taxation and the other is taxed only on realization. Assuming the taxpayer anticipates an increase in the value of the investment, the taxpayer will want to invest in the asset taxed on realization and thus postpone the payment of tax. Thus if an accrual system were adopted, but some assets were left under the current system, the assets taxed on realization would become relatively more attractive investments solely because of tax considerations.

ss This issue is discussed in Part $\mathrm{D}$ below with respect to principal residences. See infra text accompanying note 126.

so See, e.g., Commission to Revise, supra note 30 , at 38 (valuations of art treasures and similar items might be made every ten years); Kelsey, Timing Considerations in the Taxing of Capital Gains under the Tax Reform Proposals, in REPORT OF Proceedings of the Twenty-third Tax Conference of the Canadian Tax Foundation 74, 75 (1972) (referring to a Canadian Government proposal that would have required stock to be valued every five years). 


\section{Statistically Based Valuation}

Under this approach, unless the taxpayer presents evidence of the change in value of a specific asset, the system would presume that the asset's value changed at the same rate as the values of similar assets. For example, to determine the tax on an old master painting that need not be valued annually, the taxpayer might apply an index published by the Internal Revenue Service on the change in value of old master paintings generally. If, in the current tax year, such paintings increased in value by $15 \%$ on the average, the system would presume the taxpayer's particular painting to have increased in value by $15 \%$ as well.

Significant practical problems argue against adopting this approach. First, the approach would require the IRS to develop the necessary indices, unless others had already compiled them. More seriously, it would require taxpayers to classify assets in order to know which index applied. This could presage a set of problems like those arising in connection with the Asset Depreciation Range (ADR) system, with its long tables of asset classes and different class lives. ${ }^{37}$

While this method might work well for some narrowly drawn classes of assets, it cannot be the preferred method for assets generally. In effect, it applies an accrual tax system using average valuations, with relatively little concern for the equity of applying it in a particular case. While the opportunity for taxpayers to challenge the IRS's valuation might moderate this characteristic, it would lead to a more complex application than seems warranted by the problem.

\section{Adjustment for Deferral of Gains and Losses}

Finally, the system could require taxpayers to adjust their gains and losses on recognition to compensate for deferral. Under a relatively simple approach, the IRS could construct tables that would increase the nominal gain or loss on an asset to reflect the interest the government could have earned on an immediate tax on gains when they occurred and the interest the taxpayer could have earned on the tax savings from an immediate deduction of losses. Construction of these tables would have to address the problems of how to allocate the total gain or loss over the period during which a taxpayer holds the asset and which interest rate(s) to use. Unless there were signs that it encouraged abuse, I would favor a simple allocation of gain pro rata over the period the property was held. ${ }^{38}$

s7 See, e.g., Rev. Proc. 83-35, 1983-1 C.B. 745.

s8 The application of a simple version of this rule can be illustrated with an ex- 
The taxpayer would multiply the adjusted gain or loss figure by an appropriate tax rate to produce a tax liability in the year the gain or loss is recognized. The tax rate might be something simple like the taxpayer's marginal rate in the year of purchase or the year of sale. Such a rule, however, could induce taxpayers to distort their economic behavior. For example, if the taxpayer anticipates selling assets at a gain, and if the tax rate in the year of purchase applies, then the taxpayer will attempt to plan purchases in years of low income. On the other hand, if the tax rate in the year of sale applies (as under current law), the taxpayer will attempt to plan sales in years of low income. An alternative method would use an average rate based on the taxpayer's various marginal rates during the period the asset was held. While this method would reduce game-playing by taxpayers, it would require more record-keeping. An even simpler rule would tax the gain at a fixed rate, at or near the maximum marginal rate for individuals.

Adjusting gains and losses for deferral is the most attractive of the four alternatives considered above because it allows for a relatively mechanical approach to the taxation of assets excluded from the accrual system without unduly inducing investment in such assets. I would allow a reconstructed loss to be used in the year of disposition, and would tax the reconstructed gain at the rate of tax applied to the taxpayer in the year of disposition.

Although this method attempts to capture the benefits of deferral, it still does allow for game-playing by taxpayers who try to choose the year in which to recognize gain or loss. Accordingly, we must not adopt this method in too many situations. Moreover, if the potential for mismeasurement of tax appears to be too great in practice, a taxpayer

ample. Suppose an asset is purchased in Year 1 and sold in Year 4 at a gain, and that the gain is deemed to accrue on a straight-line basis over the four-year period (with a full-year convention-an equal portion of the gain is assigned to each year if the asset is held for any portion of the year), with interest accruing at an annual rate of $10 \%$. For each dollar of gain recognized after four years, $\$ 0.25$ is deemed to accrue in each of the four years. The $\$ 0.25$ accrued in Year 1 will be increased by three years of $10 \%$ compounded interest, the $\$ 0.25$ from Year 2 will be increased by two years of interest, and the $\$ 0.25$ from Year 3 will be increased by $10 \%$. (Because a single tax rate will be applied to the adjusted gain, increasing the gain by an interest factor is equivalent to increasing the tax liability by an interest factor.) Thus, each dollar of gain on an asset held for four years is equivalent to $\$ 1.16$ of adjusted gain (approximately $\$ 0.33$ from Year 1, $\$ 0.30$ from Year 2, \$0.28 from Year 3, and $\$ 0.25$ from Year 4). The IRS could tell taxpayers who sold assets excluded from the current accrual system after holding them for four years to multiply the gain or loss by 1.16 to get the amount of gain or loss to which the tax rate would then apply. For a more precise estimate of the benefits of deferral, along with an adjustment for inflation, see MEADE CoMMITTEE REPORT, supra note 2, at 148-49. Because all reconstructions of this type are based on assumptions that will not apply to any particular case, I favor the relative simplicity of the proposal in the text, which does not resort to divisions of logarithms for its explanation. 
should be required to use a tax rate from a year prior to sale if the rate in the year of sale is not characteristic of the taxpayer's tax rate during the holding period of the property sold.

The rules above, while based on recognition events, would still permit the repeal of a number of nonrecognition rules in the Code: the like-kind exchange rules, ${ }^{30}$ the rules allowing corporations ${ }^{40}$ and partnerships ${ }^{41}$ to be formed tax-free, and the rules relating to tax-free corporate reorganizations. ${ }^{42}$

On the other hand, the rules of section $1033^{43}$ allowing tax-free repurchases in the case of casualty losses might be left in the Code if policymakers agree that the occurrence of a disaster is not an apt time for what the public will view as a tax detriment. In addition, the loss disallowance rules of section $267^{44}$ should remain in effect as long as the possibility of a collusive sale at a loss exists. Finally, restrictions on the use of losses similar to those in section $1211^{45}$ should be retained for these assets; otherwise taxpayers will be encouraged to bunch losses on such assets in years when other income is high.

\section{B. Overview of Individually Held Assets}

Before embarking on an analysis of how to treat individual categories of assets, one needs to identify the universe of assets held in the United States and to determine the size of each category. Of particular interest are the sizes of those categories of assets that must be treated relatively imprecisely in an accrual system. Table 1 is based on data compiled by the Federal Reserve Board on assets and liabilities of individuals at the end of 1984 . The method used to construct the table is discussed in Appendix A. The data include holdings in personal trusts, and may incorporate some assets and liabilities of nonprofit entities. ${ }^{46}$ Others have compiled data for earlier years that provide more refined

39 I.R.C. $\S 1031$ (1982 \& West Supp. 1986). This rule could be repealed because the proposed system eliminates most of the advantage of continuing an investment, so that reinvestment in similar assets need no longer be favored.

40 Id. $\S 351$ (1982 \& West Supp. 1986). Once most assets are covered either by a current accrual rule or a five year valuation rule, the protection afforded by this rule is hardly needed to encourage incorporation.

${ }_{11} I d$. $\S 721$ (1982). The reasons are similar to those related to section 351 . See supra note 40 .

${ }^{42} I d . \S \S 354-368$ (1982 \& West Supp. 1986).

43 Id. $\S 1033$ (1982).

4 Id. § 267 (1982 \& West Supp. 1986).

45 Id. § 1211 (1982).

${ }^{46}$ For a fuller discussion of the derivation of this table, see Appendix A; BoARD of Governors of the Fed. Reserve Sys., Balance Sheets for the U.S. EconOMY, 1945-1984 (1985) [hereinafter cited as Federal. Reserve Balance SheEts]. 
estimates for certain categories of assets and liabilities. One major alternative study ${ }^{47}$ is summarized in Appendix A. It and other sources of data are noted below in connection with each asset category.

Table 1

1984 Year-End Balance Sheet of Individuals in the U.S. with Assets and Liabilities at Current Cost

\begin{tabular}{|c|c|c|c|}
\hline Category & $\begin{array}{c}\text { Amount } \\
\text { (\$million) }\end{array}$ & $\begin{array}{c}\% \text { of Total } \\
1984 \\
\end{array}$ & $\begin{array}{c}\text { Avg. \% of Total } \\
1961-84 \\
\end{array}$ \\
\hline & \multicolumn{3}{|c|}{ Assets } \\
\hline Tangible assets & $7,658,379$ & 53.6 & 51.54 \\
\hline Reproducible assets & $5,023,590$ & 35.1 & 35.65 \\
\hline Residential structures & $2,919,506$ & 20.4 & 20.25 \\
\hline Owner-occ. housing & $2,415,156$ & 16.9 & 16.33 \\
\hline Other & 504,350 & 3.5 & 3.92 \\
\hline Nonres. plant \& equip. & 744,997 & 5.2 & 4.61 \\
\hline Inventories & 123,626 & 0.9 & 1.45 \\
\hline Consumer durables & $1,235,461$ & 8.6 & 9.35 \\
\hline Land & $2,634,789$ & 18.4 & 15.89 \\
\hline Owner-occupied & $1,117,551$ & 7.8 & 5.90 \\
\hline Other & $1,517,238$ & 10.6 & 9.99 \\
\hline Total financial assets & $6,639,837$ & 46.4 & 48.46 \\
\hline Demand deposits and cash & 405,280 & 2.8 & 3.46 \\
\hline Time and savings accounts & $1,876,473$ & 13.1 & 11.80 \\
\hline Money market funds & 209,732 & 1.5 & $0.31^{\mathrm{a}}$ \\
\hline Securities & $2,148,268$ & 15.0 & 20.82 \\
\hline U.S. Govt. securities & 407,197 & 2.9 & 2.62 \\
\hline Savings bonds & 76,147 & 0.5 & 1.29 \\
\hline Other Treas. issues & 252,124 & 1.8 & 1.02 \\
\hline Agency issues & 78,926 & 0.6 & 0.30 \\
\hline State \& local debt & 206,782 & 1.5 & 1.15 \\
\hline Corp. \& foreign bonds & 43,331 & 0.3 & 0.61 \\
\hline Open-market paper & -332 & -0.0 & 0.20 \\
\hline Corporate equities & $1,491,310$ & 10.4 & 16.25 \\
\hline Life insurance reserves & 229,904 & 1.6 & 2.80 \\
\hline Pension Fund Reserves & $1,398,584$ & 9.8 & 6.57 \\
\hline Miscellaneous assets & 371,596 & 2.6 & 2.71 \\
\hline Total Assets & $14,298,216$ & 100.0 & 100.00 \\
\hline
\end{tabular}

47 R. Goldsmith, The National Balance Sheet of the United States, 1953-1980 (1982). 


\section{Table 1}

1984 Year-End Balance Sheet of Individuals in the U.S. with Assets and Liabilities at Current Cost (continued)

\begin{tabular}{lrcc}
\hline & $\begin{array}{c}\text { Amount } \\
\text { (\$million) }\end{array}$ & $\begin{array}{c}\text { \% of Total } \\
1984\end{array}$ & $\begin{array}{c}\text { Avg. \% of Total } \\
1961-84\end{array}$ \\
\hline & \multicolumn{3}{c}{ Liabilities } \\
\cline { 2 - 4 } Mtgs, owner-occ. nonfarm & $1,325,035$ & 9.3 & 8.09 \\
Noncorp. bus. mtg debt & 515,541 & 3.6 & 2.94 \\
Consumer credit & 577,098 & 4.0 & 3.79 \\
Security credit & 34,595 & 0.2 & 0.30 \\
Other debt & 361,719 & 2.5 & 2.25 \\
$\quad$ Total liabilities & $2,813,988$ & 19.7 & 17.38 \\
$\quad$ Net Worth & $11,484,228$ & 80.3 & 82.63 \\
\hline
\end{tabular}

a. Money market fund assets have been listed as a separate asset on the balance sheets only since 1974. The average since 1974 is $\mathbf{0 . 6 8}$. However, before that time there was presumably only a negligible amount of assets in such funds.

\section{G. Financial Assets}

\section{Savings Accounts, Checking Accounts, and Money Market Fund Shares}

Assets consisting of essentially cash and cash equivalents constituted over $17 \%$ of the total assets held by individuals in $1984 .^{48}$ Except to the extent that the system attempts to deal with inflation explicitly, ${ }^{49}$ it should not need to include these assets in an accrual system. They retain the same nominal value from year to year, and any increases in value derived from them are reflected in interest payments already included in income. ${ }^{50}$

48 For totals of demand deposits and currency, time and savings accounts, and money market fund shares, see table 1, supra pp. 1125-26. The average for 1961-1984 is about $15.6 \%$. Both the Federal Reserve Tables and Goldsmith's data for 1975 present similar percentages. See Appendix A, table A-1 \& table A-2; Federal Reserve BALANCE SheETs, supra note 46; R. GoldSMITH, supra note 47.

40 See infra text accompanying notes 252-55.

so Taxing cash equivalents presents other potential problems. Both the present system and an accrual system must address the issue of whether and how to tax income-in-kind items, such as the benefits given by banks to depositors who maintain a minimum balance in a checking account. The present system does not attempt to value such items. If Congress in adopting an accrual system omitted these items from the yearly valuation requirement it would create no additional problems. Although there would be fewer other untaxed income items under an accrual system, which might exacerbate the problem of valuing income-in-kind, the high marginal rates of the cur- 


\section{United States Government Securities}

Securities issued by the United States government make up a little less than $3 \%$ of assets held by individuals. ${ }^{51}$ These financial assets increase and decrease in value while also yielding interest income. Because the changes in value reflect only changes in market interest rates, not changes in the creditworthiness of the United States government, ${ }^{\mathbf{5 2}}$ the IRS could be required to publish tables listing the values of United States government obligations with various combinations of interest rates and maturities. Taxpayers would use these values in calculating gain or loss on government securities. ${ }^{53}$

An even better solution is available for the bulk of United States obligations, which are not in bearer form. ${ }^{54}$ The tax law could require the United States government as debtor to mail to holders of such obligations (with a copy to the IRS) the information needed to compute tax liability-the value at the end of the year based on a market indicator set by statute. ${ }^{\delta 5}$ While this will increase costs to the United States, it

rent system, which also exert significant pressure on taxpayers to create structures that produce untaxed income, would be reduced. See MEAde Committe REPorT, supra note 2 , at 7-11. An accrual system permits a decrease in tax rates, and hence a reduction in pressure to create such arrangements, by increasing the tax base. For discussion of the measure of the increased tax base created by an accrual system, see Appendix B.

s1 See table 1, supra pp. 1125-26. This figure is higher than the 1961-1984 average. See id. In contrast, Goldsmith's data show only $1.8 \%$ of all individually held assets in United States government securities in 1975, see Appendix A, table A-2, but much of this difference may be explained by an increase in holdings of government securities by individuals in the interim.

s2 See R. Brealey \& S. Myers, Principles of Corporate Finance $§ 7-1$, at 118 (2d ed. 1984). Although some argue that changes in values resulting from changes in interest rates should not be taxed, that conclusion clashes with the Haig-Simons definition of income. See Shachar, supra note 11, at 1852-55. For an explanation of the Haig-Simons definition, see supra note 10 and accompanying text.

ss Since the information on values would not be available until after December 31 , it could not be sent to taxpayers as a matter of course with their tax forms. Taxpayers owning United States debt in bearer form, at least, would thus have the burden of obtaining the information for themselves.

st Since the enactment of the Tax Equity and Fiscal Responsibility Act of 1982, Pub. L. No. 97-248, § 310, 96 Stat. 324, 595-600 (1982), all federal obligations (except those with a maturity of less than one year and certain obligations issued to foreigners) must be issued in registered form. Of the $\$ 1,435.7$ billion marketable obligations of the United States outstanding as of January 31, 1986, only $\$ 17.7$ billion were in bearer form. Telephone conversation with Charles Haworth, Deputy Director, Office of Government Finance and Analysis, United States Department of Treasury (May 7, 1986).

os Different types of federal obligations change in value in different patterns, see Appendix A at notes 7-9. These differences are largely due to different maturities. One might question whether it is best to use the actual market quotations at the end of the year, or whether some average of end-of-year values might be best. The same question will be raised below in the discussion of traded securities. See infra notes 81-82 and accompanying text. 
will decrease compliance costs for taxpayers. It will also result in the IRS receiving more information on who has taxable income from these debt instruments, thus increasing compliance with the tax laws. Since it is now accepted that the tax law can place reporting obligations on the United States government, and so treat it like other debtors, ${ }^{86}$ this aspect of the proposal will not be a major change for our tax system.

\section{Other Debt}

State and local obligations, corporate and foreign bonds, and openmarket paper constitute about $1.8 \%$ of all assets held by individuals. ${ }^{57}$ If such debt is publicly traded, a rule requiring the obligor to send information about end-of-year value to the debtholder should work well..$^{88}$ On the other hand, if the debt is not publicly traded, valuation would be difficult. Moreover, if the debt is not only privately traded but also issued by a foreign entity, getting information on value to the holders would probably be impossible, because an obligation to furnish the relevant information could not easily be imposed on foreigners. ${ }^{58}$

To the extent that the value of debt depends solely on interest rates and dates of maturity, it is possible to determine this value mechanically. ${ }^{60}$ Unfortunately, other variables can affect the value of debt. The debtor's creditworthiness affects the fair market value of the debt, and thus the value of debt can change when the creditworthiness

${ }^{\text {sB }}$ See, e.g., I.R.C. $\S 6041 \mathrm{~A}(\mathrm{a})$-(b), (d)(1) (1982) (requiring certain persons receiving services or selling products to make information returns and defining "person" to include "any governmental unit and any agency or instrumentality thereor"); I.R.C. $\S 6049$ (a), (d)(1) (1982) (requiring every "person" who pays interest over $\$ 10$ to make a return and defining "person" to include "any governmental unit and any agency or instrumentality thereof"); I.R.C. § 6050H(a), (c) (Supp. II 1984) (requiring persons receiving interest on mortgages of $\$ 600$ or more to make a return and defining "person" to include any "governmental unit and any agency or instrumentality thereof").

${ }^{67}$ See table 1, supra pp. 1125-26. Goldsmith's figures are approximately the same for 1975. See Appendix A, table A-2. Note in addition that the category on which this section is based excludes other debt, such as mortgages.

s8 See infra text accompanying notes 81-82.

69 According to Goldsmith, less than one-tenth of U.S. investment abroad in 1975 was investment in foreign bonds, while seven-tenths was in direct investments and bank and government loans. See R. GoldSMITH supra note 47, at 177. Goldsmith reports $\$ 264$ billion of U.S. investment abroad in 1975 . See id. at 174 table 80 . If $10 \%$ of that total were in foreign corporate bonds held by individuals, it would constitute less than one-half of one percent of all assets of individuals. Presumably, a substantial portion of such bonds are held by U.S. corporations. Of course, if foreign bonds were given special treatment, there is a danger that holdings of them would increase. To the extent foreign bonds are publicly traded, it may be possible to require reporting by the debtor.

Bo See, e.g., R. BREALEY \& S. MYERS, supra note 52, at $\$ \S 4-1$ (determining the value of government bonds), 20-1 (determining the value of an option), 21-1 to 21-2 (determining the value of risky debt). 
of its issuer changes. ${ }^{61}$ The determination of a creditor's creditworthiness cannot easily be associated with mechanical determinations, except with respect to large public corporations whose debt instruments are rated by the major credit agencies. ${ }^{62}$

Additional problems arise when provisions peculiar to particular debt instruments enter into the valuation. If the debt is convertible into another security, for example, the value of the debt may depend more on the value of the financial instrument into which it can be converted than on the general price level of the credit markets. ${ }^{63}$ The nature of any property that secures the debt may also affect the value of the debt, as may special provisions that allow the corporation to call the debt ${ }^{64}$ at its request or take other action that could affect the riskiness of the loan.

Recent changes in the tax law have attempted to identify any portion of the gain on a debt instrument that can be ascribed to anticipated interest return on the debt. This return includes not only original issue discount, ${ }^{65}$ but also any market discount. ${ }^{66}$ The owner of debt, under existing law, must pay an annual accrual tax on original issue discount. $^{67}$ Present law does not require taxpayers to accrue and pay tax on market discount annually, but it does characterize gain on sale as ordinary income to the extent it represents accrued market discount. ${ }^{68}$ Thus, procedures for calculating market discount already exist. A more complete accrual system could be achieved by applying these procedures to all outstanding debt.

Accruing the interest on debt does not account for changes in the

61 For example, bonds are rated on the basis of "judgments about firms' financial and business prospects." Id. at $\S 21-6$ table 21-6. If there is a significant change in a company's financing or prospects, the rating, and thus the value of the bond, will change. See id. at $\S 21-4$.

${ }_{62}$ See, e.g., STrandard and Poor's Bond Guide (1985).

63 For a discussion of the method of valuing convertible bonds, see R. BREALEY \& S. MyERS, supra note 52 , at $\S 23-2$. is due.

"To "call the debt" is to repay the amount borrowed before the final date that it

${ }^{65}$ See I.R.C. $\$ 1272$ (a) (Supp. II 1984) (including in income an amount equal to the sum of the daily portion of the original issue discount for each day on which a person held the debt instrument). The original issue discount is any excess of the stated redemption price at maturity over the issue price of the debt instrument. See id. $\S 1273(\mathrm{a})$.

o6 See id. § 1276(c) (West Supp. 1986) (setting out the method for determining the amount of accrued market discount). Market discount is any excess of the stated redemption price of the debt instrument at maturity over its basis immediately after its acquisition by the taxpayer. See id. $\S 1278$ (a)(2) (Supp. II 1984). Section 1276(c) complements the rule in $\S 171$, which has long allowed a deduction for market premium as well as for original issue premium. See I.R.C. $§ 171$ (a)-(b) (1982).

B7 See I.R.C. \& 1272(a) (Supp. II 1984).

s8 See id. § 1276(a). 
value of the principal of the debt. Most state and local obligations, as well as corporate and foreign bonds held by individuals, are presumably publicly traded ${ }^{69}$ so current valuation should be possible for many of these instruments. Moreover, open-market paper should pose few valuation problems; it is often sufficiently short-term that its value fluctuates very little. ${ }^{20}$

For those debt instruments with values taxpayers cannot easily measure, two possible solutions exist. The better solution, in my view, would require taxpayers to prepare a reasonable estimate of these values based on the relationship between the interest rate on the debt and some benchmark rate such as an average federal rate in the year they make the loan. ${ }^{71}$ For example, if the benchmark rate in the year of the loan is $10 \%$, and the taxpayer lends at $15 \%$, this method would value the debt in subsequent years using a rate $150 \%$ of that year's benchmark rate. ${ }^{72}$

If this method is viewed as too cumbersome, the system could exclude these debt instruments from strict accrual treatment, and adjust gains and losses for deferral in the manner advocated above for assets excepted from annual valuation. ${ }^{73}$ This second solution-removing untraded debt instruments from the accrual system-could encourage people to invest in these instruments, but such a result seems unlikely. Normally taxpayers favor a realization system because they can control when to sell their assets and so realize losses and gains; selling debt instruments that are not publicly traded is likely to be difficult, however, because such debt will probably be illiquid and subject to large discounts on sale. Moreover, the system developed above for assets ex-

69 To the extent state and local governments borrow directly from entities, such borrowings are presumably from institutions such as banks and insurance companies rather than individuals. Individuals hold directly only about one-third of all state and local government debt. See 2 Treasury Proposals, supra note 26, at 252.

70 See R. Brealey \& S. MYers, supra note 52, at 686 (average maturity of commercial paper is approximately six weeks); id. at 687 (bankers' acceptances generally mature in one to three months). Commercial paper and bankers' acceptances are the two components of open-market paper.

${ }^{71}$ If, as I suspect, most of the $1.8 \%$ of all assets held by individuals that consist of state and local obligations and corporate and foreign bonds, see table 1, supra pp. 1125-26, are publicly traded, this difficult-to-measure category may consist of little more than $0.1 \%$ of all assets of individuals.

${ }^{72}$ To continue the example in the text, if the current year's benchmark rate is $15 \%$, and the obligation under consideration had a rate of $150 \%$ of the benchmark rate in the year it was entered into, we would discount this obligation using a discount rate of $22.5 \%$ ( $150 \%$ of $15 \%)$. An even simpler system would simply calculate factors that would be used to adjust the values of all loans entered into in a particular year. For example, we could say that at the end of 1985 the value of all loans entered into in 1980 was $103 \%$ of what they were worth at the end of 1984 .

${ }^{73}$ See supra notes 38-45 and accompanying text. 
cepted from annual valuation will normally absorb the expected benefit of deferral. Accordingly, removing nonpublicly traded debt from the accrual system should not create a large market in a new tax-shelter investment.

At a more fundamental level, should debt be included in the accrual tax system at all? Because debt represents simultaneously a liability for debtors as well as an asset for creditors, any gain on the creditor's side-resulting, for example, from the right to receive interest at a fixed rate above the current market rate-may be matched by an offsetting loss on the debtor's side as long as there is no systematic difference between the tax rates of debtors and creditors. ${ }^{74}$ Thus, this elaborate system of valuation may produce no net change of income in the tax base. If that is so, is the effort worth it?

One response to this question is that even if the amount of income in the system as a whole is unchanged by the accrual method, the measurement of income for particular taxpayers will be changed in a way that better measures their economic income. Thus, applying the accrual method to debt will produce a fairer tax system. ${ }^{75}$ Nevertheless, this answer may not be sufficient if the burden of applying the system is great and the increase in fairness only marginal.

There is, however, good reason to think that the amount of income in the system as a whole will be changed substantially, and hence that the increase in fairness due to an accrual system is more than marginal. The reason is that United States government obligations make up about half of all the debt held by individuals. ${ }^{76}$ For such obligations there is no taxpayer on the debtor's side, so that changes in the value of the debt will have a net effect on the tax base.

Once the accrual system includes United States government obliga-

74 See infra notes 199-201 and accompanying text.

${ }^{75}$ See Prfsident's Tax Proposals, supra note 3, at 213. This proposal limits the use of cash method accounting and encourages the use of accrual accounting because it recognizes that

[t]he cash method of accounting frequently fails to reflect the economic results of a taxpayer's business over a taxable year. . . . Obligations to pay and rights to receive payment are disregarded under the cash method, even though they directly bear on whether the business has generated an economic profit or a loss.

Id. The economic accrual of income, described in this Article, is not identical to an accountant's accrual of income, referred to in the President's proposal.

${ }^{78}$ United States debt was $2.9 \%$ of total individual assets at the end of 1984, compared to $1.8 \%$ for state and local obligations, corporate and foreign bonds, and openmarket paper. See table 1, supra pp. 1125-26. Including the other debt obligations, mainly mortgages, that are classified under the "Miscellaneous" category, see infra note 107 and accompanying text, adds approximately $1.5 \%$ more into the private category, making the final totals $2.9 \%$ for United States debt and $3.3 \%$ for other debt. 
tions, it becomes unattractive to exclude other forms of debt. United States debt and other debt compete in the marketplace. If one is in the accrual system and the other is not, investors may prefer one to the other for tax reasons. This distortion leads to the type of tax planning that the accrual system seeks to limit. Hence, the accrual system should include as much debt as possible.

\section{Corporate Equities}

Corporate equities constitute $10.5 \%$ of all assets held by individuals. ${ }^{77}$ Corporate equities have been a particular focus of those considering the possibility of accrual taxation, both as part of an overall accrual taxation scheme, ${ }^{78}$ and as part of accrual schemes that include only publicly traded corporate securities. ${ }^{79}$ The reason for this attention is clear: publicly traded stock is both easily valued and highly liquid. Thus, the two major problems inherent in accrual taxation, valuation ${ }^{80}$ and liquidity, substantially disappear when publicly traded stocks are considered.

What value should be used to measure gains and losses on publicly traded stocks at the end of the year? The simplest solution would use the value on the last day of the year. Such a rule would arguably en-

77 See table 1, supra pp. 1125-26. This percentage is substantially less than the 1961-1984 average of 16.25\%. See id. Goldsmith's figures reveal an even lower percentage in corporate stock-only $8.5 \%$ of 1975 assets. See Appendix A, table A-2. A significant portion of the difference may be traced to the $2.8 \%$ of individuals' assets in trust funds, listed separately in Goldsmith's table. See R. GoldSMITH, supra note 47, at 114-15 table 47. Trust fund assets are included in the Federal Reserve figures for individuals. See Federal Reserve Balance Sheets, supra note 46, at 16.

${ }_{78}$ See, e.g., CommISSION TO REviSE, supra note 30, at 16-17 (proposing that stockholders include in their individual incomes dividends received, plus or minus appreciation or depreciation of stock values during the year); David \& Miller, A Proposal for Revision of Capital Gains Tax Provisions of the Federal Internal Revenue Code, reprinted in Tax Reform, 1969: Hearings Before the House Comm. on Ways and Means, 91st Cong., 1st Sess. 4275, 4281-82 (1969) (advocating a system in which tax would be due in the year of gain if a gain were recorded, and losses could be used to offset other items of income); TwENTIETH CENTURY FUND, supra note 8, at 476-84 (recommending the repeal of the undistributed profits tax as it then stood and advocating that individuals be required to value their shareholdings each year).

${ }_{70}$ See, e.g., Slawson, Taxing as Ordinary Income the Appreciation of Publicly Held Stock, 76 YALE L.J. 623 (1967); Thuronyi, The Taxation of Corporate Income-A Proposal for Reform, 2 AM. J. TAX PoL'y 109 (1983); Note, Realizing Appreciation Without Sale: Accrual Taxation of Capital Gains on Marketable Securities, 34 Stan. L. Rev. 857 (1982).

80 Even for the most widely-traded stocks, valuation problems arise, for example, in relation to the value of large blocks and control blocks. One proponent of accrual taxation of stock discusses these questions in some detail, and reaches the seemingly reasonable conclusion that large blocks and controlling shares should be taxed the same as other stock in order to avoid granting a substantial privilege to a very few, wealthy individuals. See Slawson, supra note 79 , at 647-51. 
courage some large shareholders to manipulate prices at the end of the year. However, this seems unlikely since an end-of-year valuation rule under current law has worked with apparent success in the case of futures contracts. ${ }^{81}$ Inasmuch as the futures markets are less regulated than the stock market, the natural forces in the marketplace should provide enough protection against price manipulation in the market for corporate equities. If, however, manipulation of end-of-year stock prices became a problem, the accrual tax system could use an average of closing prices for some period at the end of the year, perhaps two weeks or a month, with a longer period for stock that trades in a less active market. ${ }^{82}$

The treatment of corporate stock that is not publicly traded raises more serious problems. Although the data for making an estimate require significant qualification, roughly $15.9 \%$ of all stock held by individuals (1.8\% of all assets held by individuals) come from corporations for which values cannot easily be obtained. ${ }^{83}$

Several earlier proposals have suggested methods for valuing nonpublicly traded stock. The Twentieth Century Fund, for example, suggests that valuations of unlisted stocks be based on percentage changes in book values. ${ }^{84}$ Such an approach is ill-suited for untraded companies, which are mostly small closely held corporations that can too easily manipulate their book values. ${ }^{88}$

81 See I.R.C. $\S 1256($ a)(1) (1982 \& West Supp. 1986) (gain or loss calculated by taking the fair market value of the contract on the last business day of the taxable year).

82 No matter what period is chosen, stock purchased during that period should not have gain or loss recognized for it in the year of purchase. Otherwise, one could buy stock on December 31 and know with substantial assurance that the purchase would result in a gain or a loss for that year. Such a rule would invite purely tax-motivated planning: buy on December 31 with a guaranteed loss, sell at a tax "gain" on January 2 , thus rolling over some income into the following year.

8s The best source for this conclusion is the IRS summary of data from 1965 estate tax returns. Intrkernal. Revenue Serv., Statistics of INCOME, 1965: FiduciARY, GiFr AND Estate TAX REruRns 72 table 1 (1967). The data are analyzed in Blume, Crockett, \& Friend, Stockownership in the United States: Characteristics and Trends, 54 Survey of CuRRent Bus. No. 11, at 16 (Nov. 1974) (published by the Bureau of Economic Analysis, United States Department of Commerce). The 1965 data show that, for estate tax filers who distinguished closely held, that is, untraded, stock from traded stock, untraded stock was $15.5 \%$ of traded stock. Blume and his coworkers increase the actual dollar figures by $25 \%$ to account for stock held by persons who would not file estate tax returns. They then estimate the extent to which such stock was stock of Subchapter S corporations. They conclude that, in 1971, $\$ 61$ billion of untraded stock was stock of Subchapter $S$ corporations and $\$ 33$ billion was stock of other corporations. They then compare the total, $\$ 94$ billion, with total direct holdings by individuals in 1971 of $\$ 590$ billion in domestic stock, yielding $15.9 \%$, as cited in the text. See id. at 21-23, 34.

si See Twentieth Century Fund, supra note 8, at 477-78.

8s This may not disqualify the use of book value for those who would compare an 
David and Miller propose a system in which accountants would regularly value untraded securities. In the intervening years, taxpayers would assess increments in value using an index of asset values published by the Treasury Department. As an additional check on the process, the owners of business interests evaluated under this system would have to publish the valuation with a binding offer to sell those interests at a fixed percentage above their official valuations. ${ }^{86}$

Unfortunately, the threat of forced sales would not lead to accurate stock valuations in most situations. This tactic works relatively well when applied to real estate, which potential buyers can often evaluate by visual inspection and review of public records. In contrast, closely held corporations can usually be valued only after an inspection of their books, which owners will legitimately balk at as a regular practice. Furthermore, unlike real estate values, the value of many closely held corporations derives largely from the involvement of their owners with the business; if owners sold their interest much of that value would dissipate.

An alternative to these two proposals is to reduce the need to value nonpublicly traded stocks. This result can be achieved in two ways. First, the tax system can eliminate the tax on the stock of corporations that are taxed like partnerships ("S corporations"). ${ }^{87}$ In order to understand why this approach makes sense one must consider how the accrual system will tax the owners of sole proprietorships and partnerships. Changes in the values of assets of sole proprietorships and partnerships should be taxed directly to their owners and partners respectively. ${ }^{88}$ If a pass-through rule is adopted for partnerships, it

accrual system to current law. Under current law, about two-thirds of untraded corporations are taxed like partnerships. See supra note 83 (presenting evidence that $\$ 61$ billion out of $\$ 94$ billion in untraded stock represented stock in $S$ corporations, which are taxed like partnerships). Many observers believe that such corporations manipulate their income figures under current law. This manipulation is evidenced by one bittersweet summary of a discussion of accrual taxation: "The lawyers and investment counselors present emphasized the valuation difficulties that might arise with accrual. They pointed out that since a closely held corporation can show almost any income it wants, it would be very difficult to obtain a valuation for tax purposes." M. DAvid, supra note 8 , at 215 . The lawyers and investment counselors in the quoted passage did not explain why a system that relies indirectly-through valuations-on income figures of closely held corporations would be worse than the current system, which relies directly on those same income figures.

${ }^{88}$ See David \& Miller, supra note 78 , at 4282.

87 See I.R.C. $\S \S 1361-1379$ (1982 \& West Supp. 1986).

${ }^{88}$ This conclusion seems unavoidable in the case of sole proprietorships, whose assets are owned directly by individual taxpayers. In the case of partnerships, it reflects the common treatment of partnership income as if a partnership were an aggregate of its partners, not a separate entity unto itself. See generally 1 W. MCKEE, W. NELSON \& R. Whitmire, Federal Taxation of Partnerships and Partners \ 1.02 [3] 
should also apply to $\mathrm{S}$ corporations. Therefore, the shareholders of an S corporation would recognize the corporation's income and loss directly, including increases and decreases in the value of its assets. There would be no need to tax the change in the value of stock in $S$ corporations. ${ }^{89}$

The second method of reducing the need to value nonpublicly traded stock involves providing an incentive for more corporations to become-and remain - publicly traded, and hence capable of valuation. One incentive structure that is consistent with an accrual system is the elimination of the corporate income tax for publicly traded, but not for closely held, corporations. Current law uses the corporate tax to provide immediate taxation of corporate income, while deferring direct taxation of shareholders until either the corporation makes a distribution or the shareholder disposes of stock. An accrual system, on the other hand, would tax shareholders immediately on the increases and decreases in the value of their shareholdings. Those increases and decreases, in turn, would reflect the income or loss incurred at the corporate level, plus the changes in values of corporate assets. ${ }^{90}$ Since an accrual system would tax shareholders directly, little reason would remain to tax the corporation separately. Thus, for corporations whose shareholders are taxed on changes in the value of their shares, ${ }^{91}$ that is,

(1977) (describing the present blend of entity and aggregate treatment).

${ }^{89}$ Eliminating the accrual tax on $\mathrm{S}$ corporation stock would leave shareholders with the problem of valuing the business assets represented by their shares. This problem will be treated in a later section. See infra notes 162-98 and accompanying text.

${ }^{20}$ See infra notes 162-98 and accompanying text for discussion of business assets.

91 Two categories of shareholders might not be easily taxed on these changes in value: foreigners and tax-exempt entities. Commentators have viewed the treatment of foreigners as a serious problem in the implementation of an accrual system. See, e.g., Shoup, supra note 8, at 100-01. Indeed, the problems of dealing with foreign shareholders was a major reason that the Carter Commission, which thoroughly considered major tax revisions in Canada in the 1960's, decided not to eliminate the corporate tax.

See 4 RePort of THE Royal. Commission on Taxation 5-6 (1966).

Nevertheless, both the 1984 Treasury proposals and the President's 1985 proposals included partial integration of corporate and individual income taxes with special treatment of foreigners. See President's TAX Proposals, supra note 3, at 125-26 (imposing a compensatory withholding tax on dividends paid to foreign shareholders who are not entitled to the benefits of a bilateral treaty); 2 Treasury Proposals, supra note 26, at 139-40 (denying deduction of one-half of dividends paid to foreign shareholders by imposing a compensatory withholding tax on deductible dividends paid to foreign shareholders). In light of the willingness of Congress to impose a complex withholding system in the case of sales of real property by foreigners, see, e.g., I.R.C. $\S 1445$ (Supp. II 1984) (imposing a tax equal to $10 \%$ of the amount realized on the disposition of a domestic real property interest by a foreigner); id. $\S 6039 \mathrm{C}(1982 \&$ Supp. II 1984) (requiring any foreign person holding direct investments in domestic real property interests to make a return setting forth certain information), rules in the area of corporate stock should be easy to devise and accept.

$\Lambda$ less severe problem is presented by tax-exempt holders of corporate stock. Neither the 1984 Treasury proposals nor the President's 1985 proposals attempts to offset the advantages tax-exempt entities would have in a tax world with partial inte- 
publicly traded corporations, there is a strong argument for eliminating the separate corporate income tax. ${ }^{92}$

Despite the reduction that these reforms could effect in the number of nonpublicly traded corporations whose stocks would have to be valued, some of these corporations would remain. For taxpayers holding shares in these closely held non-S corporations, with stocks comprising about $0.6 \%$ of all assets held by individuals, ${ }^{83}$ the system should adopt the method described above for treating assets excepted from the annual accrual system.

One alternative might be noted for future consideration. The system could experiment with full integration for these nonpublicly traded corporations. ${ }^{94}$ All closely held corporations would then be treated

gration. Under current law, tax-exempt entities are taxed on income earned by unrelated businesses that they own directly, see I.R.G. $\$ \S 511-513$ (1982 \& West Supp. 1986), but not dividends received from corporations or capital gains on stock of a corporation, see id. $\S \S 512(\mathrm{~b})(1) \&(5)$. Because the tax on unrelated business income was introduced to prevent unfair competition from tax-exempt entities, only those tax-exempt entities that run a business directly are viewed as able to trade on their exemption. See S. Rep. No. 781, Part I, 82d Cong., 1st Sess. 29 (1951) (stating that income derived from any "unrelated business activities carried on by state universities and other schools of governmental units should be taxed in order to avoid "opportunities for unfair competitive advantage"). This conclusion is troubling even under current law, since a shareholder's pre-tax return on investment in a corporation should be about the same as the pre-tax return on direct investments. This follows from the fact that a taxable individual investor who is choosing between a noncorporate investment and a corporate investment presumably expects the corporate investment to yield as much as the noncorporate investment after the corporate tax is taken into account. Thus, whether or not the corporate income tax were eliminated under the accrual system, some tax should be imposed on tax-exempt entities that are shareholders, unless the reason for their exemption is to be totally reexamined. For a discussion of the comparable problems under integration proposals, see, e.g., C. McLure, Must Corporate INCOME BE TAXED TWICE? 169-73, 185-214 (1979).

92 Abolition of the corporate tax might have seemed even more radical if it had been suggested a few years ago, but after the introduction of ACRS in 1981, it became realistic to consider a corporate income tax system that, in fact, collected little from its targets. In the period 1975-1985, while the percentage of total federal receipts represented by the individual income tax rose from $47.3 \%$ to $50.9 \%$, the percentage represented by the corporate income tax fell from $14.5 \%$ to $9.1 \%$. See A. ANDo, M. BLUme \& I. Friend, The Structure and Reform of the U.S. TAX System 28 table 2.3 (1985). Proposals linking abolition of the corporate tax with an accrual tax on shareholders have been made before. See, e.g., Thuronyi, supra note 79, at 121 .

${ }^{93}$ As indicated in the text at note $83,1.8 \%$ of all assets are in hard-to-value corporations. Two-thirds of these are taxed like partnerships, see supra note 85 . Thus, only one-third of $1.8 \%$, or $0.6 \%$, consist of corporations we need be concerned about.

84 Note that eliminating the corporate tax differs from full integration, under which the income of the corporation is taxed directly to the shareholder. Under some forms of integration, it is possible to pass tax incentives (such as investment tax credits) through to shareholders. See, e.g., C. McLuRE, supra note 91, at 92-145. A pure accrual system that abolishes the corporate tax would not normally apply any tax-based incentives to corporate activity, because the corporation has no tax liability against which to take a tax credit or deduction. To retain tax incentives for corporate activity, policymakers must either devise an equitable allocation of tax benefits to shareholders, 
under an expanded Subchapter S. Since they are generally smaller corporations, they would normally have simpler capital structures than larger corporations, and thus would not offer the kinds of problems in implementing integration that more complicated corporate structures raise. ${ }^{95}$ The danger with expanding Subchapter $S$ to deal with these corporations is that the system would either need to restrict the corporations in their capital structures or to devise elaborate rules for dealing with the allocation of income and loss in the context of complicated capital structures. In the latter case, it is unlikely that all forms of manipulation can be avoided, thus opening up a new area for tax complexity.

\section{Life Insurance and Pension Reserves}

Life insurance and pension reserves constitute $11.4 \%$ of all assets held by individuals. ${ }^{96}$ The fact that their earnings are not taxed to beneficiaries has not escaped notice in the past, as commentators have considered taxing those earnings, even under the present realization system. $^{97}$

thereby solving a basic problem in implementing full integration, or allow corporations to cash in on the incentives so the incentives actually increase the value of the corporation.

95 The problems raised by the complicated capital structures of large firms that issue more than one class of stock has led to consideration of a system of integration applied only to small firms. McLure, however, considers such a proposal, in the integration context, "a shell not worth the effort." C. McLuRE, supra note 91, at 157. It should be noted that many small corporations will have a class of preferred stock owned by the founders of the corporation that was created for estate planning purposes. Such stock can be dealt with in an integration system by assigning corporate income to its holders in an amount equal to the dividends paid on the stock.

${ }^{96}$ See table 1, supra pp. 1125-26.

97 See, e.g., Prisiden'r's Tax Proposals, supra note 3, at 254-58 (proposing to include in income yearly increases in the amount by which the life insurance policy's cash surrender value exceeds the policyholder's investment in the contract); 2 TrEASURY PROPOSALS, supra note 26, at 257-62 (advocating taxation of inside interest built up in life insurance policies as measured by changes in surrender value); see also BI.UEPRINTs, supra note 11, at 60 (proposing that insurance companies inform policyholders annually of income earned from life insurance policies and that the reported amount would be included in policyholders' income); R. GOODE, THE INDIVIDUAL INCOME: TAX 125-33 (1976) (noting that the taxation of savings earned through life insurance would result in considerable administrative inconvenience to government, insurance companies, and policyholders); Irenas, Life Insurance Interest Income Under the Federal Income Tax, 21 TAx L. REv. 297 (1966) (advocating the taxation of income from life insurance directly to the policyholder); Sunley, Employee Benefits and Transfer Payments in Comprehensive Income TAXation 75, 77-82 (J. Pechman ed. 1977) (concluding that for most insurance programs the right to receive benefits should be taxed, but for tax-transfer programs the benefits themselves should be taxed). In addition, the Treasury Department considered in 1977 a proposal to tax the interest element of cash value life insurance, but rejected it at that time because of anticipated 
Taxing insurance earnings would be feasible. The computerization of insurance companies has reached a technological level that enables them to supply policyholders with a summary of yearly earnings. ${ }^{88}$ Accordingly, President Reagan has proposed that policyholders be taxed on the annual increase in the cash surrender value of their insurance policies, net of the policyholder's total investment in the contract. ${ }^{98}$

Similarly, the tax system could fairly easily implement a tax on income from pension plans (although the decision to do so raises questions of national retirement policy which are beyond the scope of a general proposal for accrual taxation). Defined contribution pension plans create an account for each employee, and so automatically have value figures for each employee that could be used to calculate the employee's annual income. For defined benefit pension plans, assumptions would be necessary to translate the expected benefit into a current value. Nevertheless, all elements of that calculation appear to be present in the structure of the existing pension rules. The plan permits participants to ask for a statement of their benefits once each year. ${ }^{100}$ Furthermore, any defined benefit plan that offers an annuity as an option must provide the employee with an explanation of the values of the alternatives offered. ${ }^{101}$ The assumptions used in those calculations should be adaptable by all defined benefit plans to value participants' anticipated benefits.

industry opposition. See Tax Reform Option Papers Prepared by Treasury Department, September 2, 1977, for the White House, reprinted in 196 DAILY REPORT FOR Executives (BNA) 41-42 (1977) [hereinafter cited as 1977 Option Papers].

88 Both authors who considered taxation of earnings on insurance reserves in the mid-1960's expressed concern about the computational difficulties of making the calculations, but both indicated that the calculations could probably be made with the aid of computers. See R. Goode, supra note 97, at 133; Irenas, supra note 97, at 321 . The 1977 Treasury study of comprehensive income taxation recommended that total income associated with whole life insurance policies be taxed, and would have required the insurance companies to inform insureds of the amount of this income. See BLUEPRINTS, supra note 11 , at 60 .

99 See President's Tax Proposals, supra note 3, at 256. Additional investment for this purpose includes the gross premiums reduced by policyholder dividends and other distributions and the cost of renewable term insurance. Because different insurance companies charge different amounts for term insurance, it may be difficult to decide precisely how the term insurance cost should be calculated. Nevertheless, the use of IRS tables for setting the term insurance portion of the calculation should assure that no policyholder is taxed on too large an amount of income. See 1977 Option Papers, supra note 97, at 42 . Because the President's proposal does not tax unrealized appreciation generally, a special rule is provided for variable life insurance treating the policyholder as owning a pro rata share of the separate account underiying the variable policy.

${ }^{100}$ See 29 U.S.C. $\S 1025$ (1982).

101 See I.R.C. § 401(a)(11) (1982 \& West Supp. 1986); Treas. Reg. § 1.401(a)11(c)(3) (1977). 
The Treasury Department, in Blueprints for Basic Tax Reform, ${ }^{102}$ suggests a simple alternative means of including pensions in the accrual system. Rather than attempting to measure income of the pension fund attributable to each beneficiary, the proposal would tax the fund on all income earned by it. If tax rates remain the same for all relevant parties, such a tax can be combined with a current employer deduction for contributions to a pension plan and a current employee exclusion of contributions to such plans, as long as the employee is taxed on all distributions from the plan, including amounts already taxed once when earned by the fund. ${ }^{103}$

The neutrality of such a proposal depends very much on how close the pension plan's tax rates are to the tax rates of the employer, on the one hand, and those of the employee-beneficiary, on the other. If the fund is taxed at the same rate that the employee or employer would otherwise be paying, the proposal can be said to work perfectly. ${ }^{104}$

One way to ensure that beneficiaries of a pension plan receive no special tax benefit is to impose the tax at the maximum tax rate for the current year. Such an approach, however, penalizes employees who have tax rates below the maximum rate. Because the tax incentives in the pension law probably are intended, to a significant degree, to benefit just such employees, ${ }^{105}$ it would be unfortunate to have to adopt such an approach. In deciding between this simpler approach and the attribution of income approach suggested previously, the extent of unfairness to such lower income employees is important. Under current law, with its wide range of individual tax rates, an accrual system should attempt to measure each pension participant's benefits directly. If, however, Congress adopts one of the current tax reform proposals that flattens the rate structure of the tax system, the simpler proposal of taxing the income of the fund directly would become the preferred approach. ${ }^{108}$

102 BL.UEPRINTs, supra note 11 , at 56-58.

${ }^{103}$ See id. at 57; Halperin, The Time Value of Money-1984, 23 TAX Notes 751,753 (1984).

104 See Halperin, supra note 103, at 753-54.

105 That intention to benefit employees in lower tax brackets is presumably the reason for the nondiscrimination rules in the pension law. See, e.g., I.R.C. § 401(a)(4) (1982).

${ }^{108}$ Sunley suggests, as an alternative, the taxation to employees of the pension fund's earnings, rather than taxing employees on the difference in value of the vested pension benefits. See Sunley, supra note 97, at 81-82. In an accrual world, this solution would not be complete to the extent that the actual asset owned by the employee is the defined benefit. For example, if interest rates went up substantially, the plan might not need to allocate any income to the beneficiary, since the increased potential earning power of the assets in the plan would be sufficient to cover the employee's defined benefit. It might be necessary, however, to record a loss for the employee in terms of 


\section{Miscellaneous Financial Assets}

The Federal Reserve data classify about $2.6 \%$ of all individually held assets in the miscellaneous category. About half of these assets consist of mortgages held by individuals, and much of the remainder consists of claims against insurance companies, consumer credit (owed to individuals), and loans to brokers. ${ }^{107}$

Most mortgages could be treated like federal obligations. ${ }^{108}$ The discussion above of federal obligations reveals that the accrual system can value a debt instrument with a particular interest rate and maturity if it can disregard both the creditworthiness of the debtor and the possibility of special provisions in the debt instrument that might make valuation difficult. ${ }^{109}$ Arguably, neither of these problems plague most mortgages. As long as the security for the mortgage covers the amount due under the mortgage-an issue that can be resolved under the proposed method for valuing real property generally ${ }^{110}$ - the creditworthi-

the present value of the employee's defined benefit in those circumstances. Finally, note that Sunley's objections to taxation of pension earnings to employees, which depend on the fact that other assets are not taxed on an accrual basis, would not apply in a world where most other assets are taxed on an accrual basis. See id. at 82.

107 This composition can be seen by comparing the figures in the Federal Reserve's table for individuals, see table 707 ("Assets and Liabilities of Individuals") of the Federal Reserve's balance sheets for 1945-1984 (copy on file with the University of Pennsylvania Law Review), with the tables from which it is derived, see Federal. Reserve Balance Sheets, supra note 46, at 16-25 table 702 (households); id. at 2630 table 703 (farms); id. at 31-35 table 704 (nonfarm, noncorporate business). Note that table 707 for individuals includes totals for corporate farms. The categories of assets and nominal amounts, as reflected in those other tables are:

Miscellaneous Financial Assets, 1984

\begin{tabular}{lcc}
\hline Category & $\begin{array}{c}\text { Amount } \\
\text { (\$million) }\end{array}$ & \% of Total \\
\hline Mortgages & 160,366 & 43.39 \\
Farms-insurance receivable & 19,174 & 5.19 \\
Farms-equity in spons. agencies & 4,279 & 1.16 \\
Nonfarms-consumer credit & 33,384 & 9.03 \\
Nonfarms-insurance receivable & 33,630 & 9.10 \\
Nonfarms-equity in spons. agencies & 861 & .23 \\
Security credit (loans to brokers) & 18,143 & 4.91 \\
Miscellaneous & 99,738 & 26.99 \\
\multicolumn{1}{c}{ Total } & 369,575 & 100.00
\end{tabular}

The "Miscellaneous" category in the above table consists of household claims against insurance companies. Telephone interview with Elizabeth Fogler, Flow of Funds Section, Division of Research and Statistics, Board of Governors of the Federal Reserve System (Aug. 6, 1984).

${ }^{108}$ See supra notes 51-56 and accompanying text.

100 See id.

110 See infra notes 130-49 and accompanying text. 
ness of the debtor is not so substantial an issue. In addition, one does not normally expect to find significant variations in a mortgage that would affect its value. Thus, the proposed mechanism for translating debt with a fixed interest rate and maturity into a single value ${ }^{111}$ should enable the system to value the bulk of mortgages. The system could treat those mortgages that could not be valued easily (for example, those in default or those for which the security has dipped below the amount due) under the method described above for assets excluded from annual valuation.

Like mortgages, loans to brokers pose few problems of valuation. These loans are essentially demand deposits held by brokers which can be withdrawn by customers at any time. ${ }^{112}$ Thus, they can be valued at their face amounts, like checking accounts, unless the broker becomes insolvent.

In contrast, insurance claims should be exempt from accrual taxation, as they are under current law. Generally, the present system assumes that the insurance claim will be paid; until then, a taxpayer cannot take a deduction on the loss for which a claim was made. ${ }^{113}$ If the accrual system maintains this rule it does not need to tax insurance claims, because the value of the assets will be largely canceled out by the losses that triggered the payment. Moreover, the fact that most individual insurance claims are likely to be for "assets" that the proposed accrual system would not cover in any event-life, health, and consumer durables-further supports a decision to exclude the insurance claim from the system.

Finally, the system should also exclude consumer credit. Consumer credit is normally sufficiently short term that its value will change very little (unless it goes into default). Accordingly, there is little to be gained from including it in the system.

\section{Tangible Assets}

\section{Owner-Occupied Housing}

Owner-occupied housing comprises one of the largest categories of assets held by individuals. The structures themselves make up $16.9 \%$ of the assets listed in Table 1 . Owner-occupied land adds another $7.8 \%$ of

11 See supra text accompanying notes 52-54.

112 The figure used for this data in the Federal Reserve balance sheets is derived from (although it is not identical to) a figure for "Free Credit Balances at Brokers" in 72 Federal Reserve Bulletrn A-25 table 1.36. A footnote to this table indicates that these amounts are "subject to withdrawal by customers on demand." Id. at n.4.

113 See Treas. Reg. $\S 1.165-1(d)(2)(1960)$. 
total assets, giving a total of $24.7 \%$ for all owner-occupied housing. ${ }^{114}$

In order to determine the most desirable treatment for owner-occupied housing under an accrual system, the special tax treatment afforded housing under the current system must be considered. Current tax law does not recognize losses from the sale of assets such as residences that are personal in nature. ${ }^{115}$ In contrast, the current tax law provides very favorable treatment for gains from the sale of a principal residence. ${ }^{116}$ Under section $1034,{ }^{117}$ a taxpayer may defer the gain on the sale of a principal residence to the extent that the taxpayer reinvests that gain in another principal residence within two years of the sale. In addition, under section $121,{ }^{118}$ a taxpayer aged fifty-five or more may exclude from income up to $\$ 125,000$ of gain on a sale of a principal residence.

Two other provisions that apply to other assets as well also offer favorable treatment of gains from the sale of residences. First, sales of owner-occupied housing receive capital gains treatment. ${ }^{\mathbf{1 1 9}}$ Second, if a homeowner dies, the fair market value of the home becomes its tax basis, shielding any accrued gain from future income tax. ${ }^{120}$

Given this background, the accrual tax advocate faces two alternative treatments for principal residences: taxing gains on principal residences on a yearly basis, or taxing these gains only on recognition, with or without the current exceptions. I will take up these two alternatives in turn.

\section{a. Including Residences in the Accrual System}

If residences are to be included in the accrual system, tax policymakers must decide whether any of the current provisions applicable to

114 Goldsmith summarizes a study of household wealth in 1962 that concluded that owner-occupied homes comprised $27 \%$ of household wealth in that year. See R. Goldsmith, supra note 47, at 137 table 57 (citing D. Projector \& G. Weiss, Survey of Financial Characteristics of Consumers (1966)). Because the Federal Reserve's data, see Federal Reserve Balance Sheets, supra note 46, show only $22.7 \%$ of assets in owner-occupied homes in 1962 , it is possible that the percentages in the text underestimate holdings of owner-occupied homes. For other detailed estimates of household wealth, see Bossons, The Distribution of Assets Among Individuals of Different Age and Wealth, in INSTITUTIONAL INvestors AND CORPORATE STOCK 394 (R. Goldsmith ed. 1973).

115 See I.R.C. $\S \S 165(c)(3), 262$ (1982 \& Supp. II 1984).

${ }_{116}$ Principal residences are a slightly narrower category than owner-occupied housing included in table 1, supra pp. 1125-26, to the extent that the former category excludes second homes.

117 I.R.C. § 1034 (1982 \& Supp. II 1984).

118 Id. $\& 121$ (1982).

110 See id. § 1221 (1982).

120 See id. § 1014 (1982 \& West Supp. 1986). 
owner-occupied housing should be retained. The general proposal outlined above eliminates favored capital gain treatment and taxes the gain on death, and there does not appear to be any reason to treat owneroccupied housing differently from other assets with respect to these two provisions. Several arguments for the special treatment of capital gains-encouraging investment and moderating lock-in effects-do not apply to principal residences, because such assets are not commercial in nature. The other arguments for capital gains treatment-preventing the bunching of income and moderating the effects of inflation-would carry less weight under an accrual system, because tax rates could be lowered and inflation could be explicitly taken into account. Except in the case of a home passing to the spouse of a decedent, when no tax should be imposed, at the time of death there is no reason to treat homes differently from other assets. The estate tax has no special rules for homes not passing to a decedent's spouse.

If the tax system gives accrual treatment to gains, should it also provide accrual treatment for losses? Under current law, losses on personal residences are not deductible. ${ }^{121}$ An accrual system must allow for losses to some extent, because recognizing gains but not losses is particularly troublesome in an accrual system: if a taxpayer overvalues a personal residence, there may never be a compensating reduction of income if the system does not allow for losses on personal residences. ${ }^{122}$ The system could solve this problem, however, with a moderate increase in record-keeping requirements, by allowing losses to be accrued to the extent they offset gains accrued previously. ${ }^{123}$

Is a system that taxes all gains on personal residences but allows losses only to the extent of prior gains a fair one? Initially it might seem more generous than current law, which taxes recognized gains on residences and never allows losses to be taken. However, the provisions for tax-free reinvestment of gains (section 1034) and untaxed gains for those over age fifty-five (section 121) eliminate the bulk of gain taxation. Indeed, if section 1034 were continued in an accrual system, there would be no accrual taxation of residences, since the increased value of an asset is always, in effect, "reinvested" in that asset.

But if section 1034 is not continued in an accrual system, the re-

121 See I.R.C. $\S \S 165$ (c)(3), 262 (1982 \& Supp. II 1984).

122 For example, suppose a personal residence that is actually worth $\$ 100,000$ is mistakenly valued at $\$ 110,000$ in one year. The $\$ 10,000$ of income created will not be matched by a compensating loss even if the asset were sold in the next year for $\$ 100,000$.

${ }^{123}$ Cf. I.R.C. $\S 267$ (d) (1982) (allowing nonrecognition of gain on the sale of property where the property was bought from a related party who did not recognize a loss on the original transfer because of $\$ 267(a)(1))$. 
striction on the use of losses under the system may properly be viewed as too severe. As Professor Epstein points out, ${ }^{124}$ losses on personal property are of two types. Some losses are the equivalent of depreciation. Since the imputed income on personal property is not recognized by taxpayers, it is inappropriate to allow business-type deductions such as depreciation. Other losses reflect changes in market conditions. Since gains on personal residences reflecting market changes are recognized by taxpayers, Professor Epstein argues forcefully that such losses should also be recognized. ${ }^{125}$

When we translate these arguments into a world of accrual taxation, we find strong reasons to exclude personal residences from the accrual system. As described more fully below, ${ }^{128}$ the accrual system will attempt to value investment and business real estate on an annual basis, taking account of changes in value due both to market changes and to wear and tear. If we include personal residences in the system, we would have to add to this process a method for differentiating these two types of changes in value. This would surely be a very difficult task, and would substantially increase the number of taxpayers who are affected by the accrual system. Since the tax system has favored personal residences over other significant investments for many years, we will not be creating important new incentives by excluding personal residences from the accrual system.

\section{b. Taxing Gains on Residences upon Realization}

The decision to exclude owner-occupied housing from accrual treatment does not end the inquiry. If we tax gains on residences upon realization, do we maintain the existing rules of sections 1034 (exemption of gains that are reinvested in another principal residence) and section 121 (one-time exemption of up to $\$ 125,000$ of gain for taxpayers over age fifty-five)? The original reasons for including section 1034 in the Code relate to the hardship of taxing persons who are compelled to move for personal reasons such as increased family size or a change in the place of employment. ${ }^{\mathbf{1 2 7}}$ Since these reasons have nothing to do with valuation problems, section 1034 could be continued in an accrual system. ${ }^{128}$ Moreover, any increase in the tax on these market gains

124 See Epstein, The Consumption and Loss of Personal Property under the Internal Revenue Code, 23 StaN. L. REv. 454 (1971).

${ }^{125}$ Id. at $471-72$.

128 See infra text accompanying notes 130-49.

122 See S. REP. No. 781, 82d Cong., 1st Sess. 34 (1951), reprinted in 1.951 U.S. Code Cong. \& AD. News 1969, 2004.

${ }^{128}$ In contrast, because I.R.C. $\S 1031$ (1982), the provision deferring tax on like- 
raises anew the question of whether market losses should be recognized. We avoid these difficult problems, which are unrelated to the accrual system, by continuing the favored treatment of gains on residences. These arguments also justify preserving the section 121 exemption.

On the other hand, the tax system should eliminate other favored treatment for owner-occupied housing. Sections 1034 and 121 provide sufficient protection for homeowners. If the system preserves these sections, it does not need to treat gain from the sale of residences as capital gain. It also should not protect gain on death, except to the extent gain on sale would have been shielded by section 121 , or where the residence is transferred to a surviving spouse. ${ }^{12 \theta}$

\section{Other Real Property}

The relatively simple solution developed for owner-occupied hous-

kind exchanges, is in the Code for reasons related to our realization structure, it would be eliminated by this proposal. See, e.g., Bittker, supra note 8, at 3 ("If taxpayers were required to value their assets annually, and to take the current increase or decrease into account currently, a number of complexities in the existing law would evaporate. Among them would be the elaborate rules regarding non-taxable [like-kind] exchanges."); see also supra notes 40-42.

${ }_{129}$ The existing tax structure greatly limits the tax revenue currently received from changes in the value of owner-occupied housing. In 1973, taxed gains from residence sales constituted approximately $3.9 \%$ of all capital gains. See INTERNAL ReveNue Service, 1973, Statistics of Income: Sales of Capital Assets Reported on Individual Income Tax Returns, Supplemental Report 21, 26 table 1 (1980) [hereinafter 1973 CAPITAL GaINS REPORTs] (showing amounts of gross gain on all assets and on sales of residences); $i d$. at 163 table 11 (showing amount of deferred or excluded gain on the sale of residences); see also Appendix A, table A-5 (reproducing some of the percentages that can be derived from this IRS study).

The current treatment of the sale of personal residences is substantially more favorable than the 1973 rules. In 1973, taxpayers aged 65 or over (rather than 55) could exclude only that portion of their gain that $\$ 20,000$ constituted of the full sales price (rather than excluding all gain up to $\$ 125,000)$. Compare I.R.C. $\$ 121$ (1982) with $i d$. $\S 121$ (1976). Nevertheless, the benefit from $\S 121$ constituted over $14 \%$ of the total benefits afforded to gains from the sale of principal residences. The current rules have increased by five or six times the amount of gain from the sale of personal residences that the tax base excludes. Compare Senate Comm. on THE Budget, 95TH Cong., 2D Sess., Tax Expenditures 163 (Comm. Print 1978) (estimate of $\$ 70$ million loss in 1980 tax collections from section 121 prior to changes made by the Revenue Act of 1978, Pub. L. No. 95-600, § 404) with StafF of the Jolnt Tax Comm., General Explanation of the Revenue Act of 1978, 257 (Joint Comm. Print 1979) (estimate of $\$ 415$ million loss after the statute passed).

Given the relatively small amount of gain from the sale of personal residences that is currently taxed, Congress should seriously consider eliminating from income calculations all gain from the sale of personal residences. After the application of $\S 1034$ and $\S 121$, the taxpayers who remain to be taxed on gains from their residences-those under age 55 who do not reinvest sufficient proceeds and those over age 55 with more than $\$ 125,000$ of gain-do not comprise a coherent group to target for taxation. It may be appropriate to exempt them from an accrual system that does not tax increases and decreases in the value of residences. 
ing will not work for other real estate, which does not enjoy the same favorable tax treatment and as to which no distinction need be drawn between changes in value due to market forces and those due to wear and tear. Land and residences that are not owner-occupied constitute $14.1 \%$ of the assets listed in table 1 , and some portion of the $5.2 \%$ of assets that are nonresidential plant and equipment consists of real estate. ${ }^{130}$ Gains that can be traced to real estate make up at least the same percentage of all recognized gains, and probably substantially more. ${ }^{131}$ Because real estate owned by individuals represents a substantial portion of all individually held investment assets that change in value, a reasonably comprehensive scheme of current valuations must find a way to incorporate these assets.

Previous proposals that have considered real estate under an accrual system generally base income tax valuations on the assessments used for calculating local property taxes. ${ }^{132}$ Unfortunately, recent developments in local self-governance limit the usefulness of such an approach. Local initiatives such as Proposition 13 in California ${ }^{133}$ and Proposition $2^{1 / 2}$ in Massachusetts ${ }^{194}$ restrict local assessors. For example, under the present law in California, local assessors can increase the valuation of property by no more than $2 \%$ each year, unless the owner sells the property so that a new value can be determined from the sale

${ }^{130}$ The land category in the Federal Reserve balance sheets appears to refer only to land associated with residences.

131 For a summary of the IRS data on capital gains reported on 1973 individual tax returns, see Appendix A, table A-5. Of all gross gains, $8.1 \%$ resulted explicitly from nonbusiness real property other than personal residences, and $3.8 \%$ of gross gains were $\S 1250$ gains, see I.R.C. § 1250 (1982 \& Supp. II 1984), which are all real property gains. In addition, $7.7 \%$ of gross gains were allocations from partnerships and fiduciaries. Because more than three-quarters of all nonfarm, nonfinancial partnerships are real estate partnerships, see R. GoldSMITH supra note 47, at 159 table 70 ("Structure of Balance Sheet of Nonfinancial Nonagricultural Partnerships, 1975"), it is likely that a large portion of that gain also arises from real estate. Another $9.7 \%$ of gross gains were gains from prior year installment sales, and based on the case law under the installment sale provision, see I.R.C. $\$ 453$ (1982 \& West Supp. 1986), it is likely that more than half of that gain arises from real estate transactions too. A LEXIS search of cases raising $\S 453$ issues decided in 1984 and 1985 shows that 12 of the 22 cases involved sales of real property.

132 For example, the Twentieth Century Fund's proposal in 1937 suggested that percentage changes in assessed values might be used as a basis for valuing real estate. See Twentieth Century Fund, supra note 8, at 490-91. Similarly, David and Miller, in their more recent proposal for accrual taxation, suggest that taxpayers submit evidence of the level of assessment of their properties, along with locally prevailing assessment ratios. Thereafter, any changes in assessments would have to be reflected as an increase in value in the federal income tax return, unless the taxpayer could submit evidence that such was not the case. See David \& Miller, supra note 78, at $\mathbf{4 2 8 2 .}$

${ }^{133}$ Cal. Const. art. XIIIA.

${ }^{134}$ Mass. Gen. Laws Ann., ch. 59, § 21C (West 1985). 
price. ${ }^{135}$ Thus, there is no longer any necessary relationship between assessments and relative values in such jurisdictions.

An alternative to reliance on government assessments might be a self-assessment system. Some commentators have suggested such a system for all assets in an accrual income tax system, ${ }^{136}$ and Professor Levmore discusses it in significant detail as a means of enforcing the local property tax. ${ }^{137}$ Under a self-assessment system, the owner reports a property value on which the tax is based. In order to ensure that a taxpayer will not understate the property value, the tax system provides an incentive to others in the private sector to check on the reported value, and if they find it to be too low, the taxpayer suffers a penalty. One straightforward approach would require the taxpayer to sell the property at the self-assessed price, or at some premium over that price. ${ }^{138}$

Another approach Professor Levmore discusses involves competitive assessments. This approach encourages private persons to submit their own assessments of properties. The person submitting the highest assessment must be prepared to purchase the property at that amount. If the owner is unwilling to sell, however, the highest assessment becomes the basis for levying the property tax. ${ }^{139}$ Professor Levmore suggests that the prospect of being able to buy the property at the assessed level may provide sufficient compensation for the private sector assessors. ${ }^{140}$ If a richer reward is needed to attract private assessors into the market, Professor Levmore suggests that a commission be given to the assessor with the highest bid when the owner chooses to accept the assessment rather than sell the property. The commission would be based on the additional revenue generated by the higher assessment. ${ }^{141}$

Whether or not the competitive assessment system might work for the property tax, it does not fit well with the federal income tax. Once a commission must be paid to attract assessors into the market, the system flounders because, unlike a local property tax, the income tax does

135 CaL. Const. art. XIIIA, § 2(b).

138 See M. DAvid, supra note 8, at 215 (report of conference discussion); see also Bradford, supra note 2, at 83 (in developing an accrual system for real estate, "one could imagine a system of self-assessment").

${ }^{132}$ Levmore, Self-Assessed Valuation Systems for Tort and Other Law, 68 VA. L. REv. 771, 778-83 (1982).

138 See M. DAvid, supra note 8, at 215; Levmore, supra note 137, at 778-83. Such a result seems unpalatable, however, to the extent that it may force persons to sell properties that they are quite happy to retain. See id. at 783-84. The force of this objection is substantially diminished in the context of this Article, because the proposal would not cover personal residences.

139 See Levmore, supra note. 137 , at 783-88.

140 See id. at 787-88.

141 See id. at 784-85. 
not have a single uniform tax rate. Thus, an increased assessment does not guarantee increased income tax revenue.

Indeed, because a taxpayer can have a zero marginal tax rate, allowing a reward for a high assessment could result in the government losing money on the reassessment. This difficulty suggests an underlying problem with using any method of assessment that the taxing authority does not control: some taxpayers under an accrual tax system will want to have their assessments increased in a particular year. Inflating an assessment is the equivalent of shifting income into the year of the inflated assessment. Such shifting may, for example, allow additional deductions to be used in that year, with the prospect of reducing the assessment in a later high-income year, generating a more valuable loss in that later year. ${ }^{142}$ This shifting could clearly take place under a self-assessment system; competitive assessments simply raise the specter of collusion between owners and private assessors, a particularly awkward possibility if commissions are to be paid to these private assessors. To combat this potential problem, new sanctions would have to be devised, which would lead the system down the treacherous road of complexity and tax planning.

The required system, therefore, must generate values for properties in a mechanical way that does not need an army of assessors, yet will produce reasonably accurate results. In theory, it seems possible to construct such a system by starting with sale prices and adjusting for increases and decreases in value since the most recent sale, based on changes in value of other properties in the same area, as reflected in their sale prices.

In fact, such systems do exist. Computer-assisted appraisal systems have been developed for local governments based on accepted statistical techniques. ${ }^{143}$ One commentator has previously suggested that such systems be employed to implement a wealth tax in the United States. ${ }^{144}$

142 Arguably, there is nothing wrong with taxpayers accelerating income into a tax year. Presumably taxpayers would accelerate income to even out their income over their lifetimes. Such an evening out has been viewed as an appropriate goal for an ideal tax structure. See Vickrey, supra note 19 , at 737 . Moreover, the taxpayer may be paying a price, since the taxpayer's income may not increase to the extent the taxpayer had anticipated. However, where the tax system does not explicitly allow all taxpayers to increase their incomes at will, a method that allows such a result for only some taxpayers will, at the least, generate a perception of unfairness, which should be avoided.

${ }^{143}$ See, e.g., A. Ghurch \& R. Gustafson, International Ass'n of Assessing Officers, Statistics and Computers in the Appraisal Process (1976); J. Dasso, International. Ass'N of Assessing Officers, Computerized Assessment ADMinistration (1974).

${ }_{144}$ See Address by R. Cooper, Taking Wealth Taxation Seriously, The Ninth Mortimer H. Hess Memorial Lecture delivered before the Association of the Bar of the 
The potential use of computer technology at least raises the possibility that a national real estate valuation system administered by the IRS could be implemented.

The magnitude of such a project mandates careful consideration before it is adopted. In those states where taxpayer initiatives have not restricted land assessors, the land assessments (or some multiple of them) might be relied upon. If, however, no reliance is made on local assessment, the total start-up cost of such a system on the national level would be between $20 \%$ and $27 \%$ of the IRS's current budget, and the annual costs thereafter would be between $7 \%$ and $15 \%$ of its current budget. ${ }^{145}$

Even the large costs of a total national assessment system might be

City of New York (May 29, 1978), reprinted in 34 RECORD OF THE Association of THE BAR OF THE CITY OF NEW YORK 24, 37 (1979).

145 National data on assessed properties can be found in 2 UnITEd STATes DeP'T of CoMmerce, 1982 Census of Governments 13 (1984). Of the 98.4 million parcels that were subject to local assessment in $1981,55.0$ million (55.9\%) were single family homes (including condominiums). Suppose, for simplicity, these were all owneroccupied, and thus excluded from the accrual tax system; then only the remaining 43.4 million parcels would have to be valued for accrual tax purposes. The rule of thumb among assessors is that the average per parcel cost of ongoing assessment operations lies in the range of $\$ 9$ to $\$ 13$. The start-up costs of parcel-by-parcel assessment is $\$ 25$ per parcel, on average. Letter from Richard R. Almy, Executive Director of the International Association of Assessing Officers, to the author (Sept. 20, 1984).

However, the costs of assessing multi-family homes are likely to be three times those amounts, while the costs of assessing commercial or industrial properties may be four times those amounts. On the other hand, the cost of valuing raw land is negligible. Telephone interview with Richard B. Almy (Dec. 26, 1985). In 1981, there were 3.2 million multi-family homes, 4.1 million industrial and commercial properties, and 34.3 million parcels of raw land that were assessed. In addition, there were 1.9 million "other and unallocable" properties. Using these figures, one can develop minimum assessment costs by assuming no cost for valuing land and "other" properties, while one can calculate maximum costs by assuming that other properties are as costly to value as commercial property, and that land costs $\$ 1$ per parcel to value. The resulting costs in millions of dollars are as follows:

Cost of Real Estate Appraisal

\begin{tabular}{lccc}
\hline & Start-up $(\$ 25)$ & Ongoing $(\$ 9)$ & Ongoing $(\$ 13)$ \\
\hline Minimum & $\$ 649.7$ & $\$ 233.9$ & $\$ 337.8$ \\
Maximum & $\$ 870.1$ & $\$ 335.1$ & $\$ 468.9$
\end{tabular}

In fiscal 1984 , the IRS spent $\$ 96.4$ million on salaries and expenses, $\$ 896.6$ million on processing tax returns, $\$ 1,250.9$ million on examinations and appeals, and $\$ 1,018.7$ million on investigation, collection, and taxpayer services, for a total of $\$ 3,235.6$ million on all administrative expenses. Executrive Office of THE PresiDENT, Office of Management and Budget, Budget of the United States GOVERNMENT 1986, at 8-166, 8-167 (1986). These figures yield the percentages discussed in the text. Some states exclude limited categories of privately-owned real property from the property tax, see, e.g., WASH. Rev. CODE ANN. $\S 84.33$ (West Supp. 1986) (forest land taxed on the basis of timber harvested from it), so the numbers of assessed properties used above may be slightly understated. 
justified in light of three considerations. First, the substantial simplification of the tax law under an accrual system should significantly reduce the costs of administering other aspects of the law. Not only will there be fewer issues to resolve but, significantly, there will be fewer complicated issues. Second, the simpler law will reduce compliance costs for taxpayers. This consideration should certainly matter to policymakers. ${ }^{148}$ Finally, the federal government will essentially be duplicating the assessment function of those local jurisdictions that attempt to base property taxes on the actual value of real property. Accordingly, it may be possible to reduce local assessment functions, generating additional cost savings from a national perspective. ${ }^{147}$

How would information generated by a national real estate valuation system be used in the administration of our tax laws? Operating analogously to local property tax systems, an accrual system could require the IRS to send the valuations developed by the system to taxpayers along with their tax forms. Since the IRS would send out those forms at the end of the tax year, the computer evaluation might be as of some earlier date in the year. ${ }^{148}$ Taxpayers could then choose to use the computer-generated value or to claim a different value on their returns. Claiming a different value, however, would presumably increase the likelihood of an IRS audit, which would thus serve as a natural brake on such occurrences, and hence on the need for a more elaborate valuation.

One aspect of this structure breaks significantly with past tax administration. Under the contemplated system, the IRS would develop an assessment and send the information to taxpayers, for use by taxpayers in the current year's tax returns. The enormous amount of personal information the IRS would have to collect requires a consideration of the possibly excessive invasion of privacy. But using the IRS to generate tax information for individual taxpayers as a matter of course

${ }^{146}$ For an example of an analysis that explicitly takes account of compliance costs, see Brannon, Simplification and other Tax Objectives, in FEDERAL Income TAX SIMPlification 191, 193-200 (C. Gustafson ed. 1979).

147 A somewhat comparable structure exists in the Code currently. Under I.R.G. $\S \S 6361-6365$ (1982 \& Supp. II 1984), the IRS is authorized to collect state taxes as part of the federal collection effort. These provisions have not proven popular because states are substantially restricted in the nature of tax systems that they can employ. See id. $\S 6362$. In contrast, the assessment system proposed in the text would simply produce valuations of properties for local governments, without limiting the ways those governments might employ the valuations.

${ }_{148}$ As discussed below in connection with implementation, see infra note 266, end-of-year valuation might be used with an extension of the due date of tax returns. Note that, because real estate is not very liquid, the likelihood of tax planning leading to sales near year end, but after the valuation date, is not great. This contrasts with the discussion of implementation, see id. 
has already been anticipated with the rise of computer capabilities. More than fifteen years ago one commentator suggested that, in connection with income averaging and bad debts, for example, the IRS might be the expected source of prior year information to be used by the taxpayer. ${ }^{149}$ Moreover, this proposed system does not involve any significant amount of knowledge that the IRS does not already have (through information on property taxes from individual returns, for example) or that is not to a substantial degree public knowledge (through local property assessments). Therefore, the maintenance of records on these values by the IRS would not necessarily raise any major privacy issues for taxpayers. In sum, this structure appears to offer a realistic approach to dealing with one of the major problem areas that could be expected to arise under an accrual income tax system.

\section{Consumer Durables and Collectibles}

Table 1 shows that $8.6 \%$ of all assets held by individuals consist of "consumer durables." This category apparently includes such potentially taxable items as antiques and works of art that are often termed "collectibles."150 Collectibles alone probably constitute no more than $1 \%$ of all assets held by individuals, and are probably closer to half that percentage. ${ }^{151}$

149 See Smith, Automation in Tax Administration, 34 Law \& Contemp. Probs. 751,753 (1969).

150 Telephone interview with Elizabeth Fogler, supra note 107.

151 The Federal Reserve based its percentage for consumer durables on data developed in Bureau of Economic Analysis, U.S. Dep'T of Commerce, Fixed RePRoducible Tangible Wealth in the United States 331-41 (1982). For 1979, the Bureau's data show the following categories of consumer tangibles:

Consumer Durables, 1979

\begin{tabular}{lcc}
\hline Category & $\begin{array}{c}\text { Amount } \\
\text { (\$billions) }\end{array}$ & \% of Total \\
\hline Automobiles & 274.9 & 31.4 \\
Other motor vehicles & 57.3 & 6.6 \\
Furniture, including mattresses and bedsprings & 115.7 & 13.2 \\
Kitchen and other household appliances & 79.8 & 9.1 \\
China, glassware, tableware and utensils & 37.5 & 4.3 \\
Other furnishings & 76.0 & 8.7 \\
Radio, TV, records and other musical instruments & 77.6 & 8.9 \\
Jewelry and watches & 52.5 & 6.0 \\
Ophthalmic and orthopedic equipment & 12.6 & 1.4 \\
Books and maps & 26.3 & 3.0 \\
Wheel goods, durable toys, sports & & \\
equipment, boats, and pleasure aircraft & 64.1 & 7.3 \\
\hline Total & 874.3 & 100.0
\end{tabular}

Of these categories, only jewelry (6.0\%) includes a substantial number of items of 
While consumer durables constitute a significant portion of all assets, they play a very small role in the tax system. The IRS study of capital gains in 1973 concludes that $12.7 \%$ of gross gain on tax returns for that year came under the miscellaneous category that would include consumer durables. ${ }^{162}$ The description of that category, however, does not refer explicitly to consumer durables; instead, it speaks of such items as mortgages and foreign currency. ${ }^{153}$ Thus, the percentage of gross gain attributable to consumer durables is probably small. Even if more precise data existed, it would probably not show much taxable gain in this area. Consumer durables are precisely that-goods that are consumed, for the most part. Any potentially taxable items, such as collectibles, that are included within this category should comprise only a small portion of the category.

Nevertheless, the relatively small number of such assets does not necessarily suggest removing them completely from the system. If policymakers removed these assets from the system, taxpayers would be encouraged to invest in them because of their tax-favored status. The potential for tax shelters and tax planning revolving around exempted consumer durables is too strong to ignore.

On the other hand, the problem with including such assets in the system is that these assets are quite difficult to value. Several tax reform proposals have recognized this difficulty. The Twentieth Century Fund, in its 1937 proposal, does not even attempt to include consumer

concern. A small portion of furniture (13.2\%) presumably consists of collectible antiques, and an even smaller portion of china and utensils (4.3\%) may be deemed items of enduring worth. Similarly, small portions of musical instruments, books and maps, and other categories may be ascribed to collectible items. The other major repository of items in which one might invest for a profit comes under "other furnishings" (8.7\%), which seems to be the only category that might include works of art. For collectible assets to constitute as much as $1 \%$ of all assets, about $12 \%$ of the consumer tangibles listed by the Bureau of Economic Analysis would need to be in the collectible category. Even if all the jewelry $(6.0 \%)$ and one-third of the other furnishings (one-third of $8.7 \%$ is $2.9 \%$ ) were in the collectible category, there would still have to be an additional $3 \%$ from the other categories to reach $12 \%$. These are very generous estimates, so an estimate below $1 \%$ of total assets seems reasonable.

Goldsmith attempts to measure collectibles, including works of art, using data on imports of collectibles, on the theory that most collectibles come from overseas. He must make some very subjective estimates to reach a final estimate. For 1975 , he finds $\$ 60$ billion worth of collectibles among U.S. assets. See R. GoldsmITH, supra note 47, at 187-88. If all collectibles were held by individuals, Goldsmith's estimate would represent about $1 \%$ of all individual assets. See Appendix A, table A-2. As Goldsmith recognizes, however, nonprofit organizations (for example, museums) hold a substantial amount of collectibles. Thus, the actual figure for individuals alone is probably closer to $0.5 \%$ of individual assets. It is not clear, though, whether Goldsmith's estimate includes jewelry.

${ }_{152}$ See Appendix A, table A-5.

${ }^{163}$ Appendix A quotes the definition in full. See note $g$ to table A-5. 
durables; rather, it excludes from the proposed system all assets that would be too difficult to value. ${ }^{154}$ Similarly, David and Miller, in their 1969 proposal, suggest that "gain or loss on personal property is sufficiently nominal that there is no need to tax such property on an accrual basis."15s Finally, the Commission to Revise the Tax Structure, in its recent proposal, states in passing that "[e]xemptions might be considered for . . . art treasures, antiques, and the like, in the same way as consumer durables which are not held for investment." are to be valued, the Commission suggests taxation on sale (or at tenyear intervals), with the additional tax liability spread back on a straight-line basis using a simple interest charge on the reconstructed deficiencies. ${ }^{187}$

Although Professor Bittker argues generally that the simplification produced by an accrual system could be worth the cost in appraisals, ${ }^{158}$ taxing consumer durables on an accrual basis probably presents too formidable a task to be worth undertaking. Fashioning an alternative treatment for consumer durables requires a clarification of the relevant concerns. In the first place, the alternative should not encourage taxpayers to invest in particular assets because of their special tax treatment. Additionally, the alternative should not put pressure on the system to decide when an asset fits into that category and when it does not. Lastly, the alternative should be workable for the assets subject to it and easy both for the taxpayer and for the tax authorities to apply.

For the most part, the system developed above for assets excepted from annual valuation satisfies these criteria. However, because these assets are passive investments and their ownership involves significant personal enjoyment, there is a danger that excluding the most expensive of them (such as valuable paintings and antiques) from a system of regular valuation will create an appearance of abuse.

Accordingly, I suggest the following system for these assets:

1. Taxpayers would be required to value assets with a purchase price greater than $\$ 20,000^{159}$ (with the exception of

\footnotetext{
164 See Twentieth Century Fund, supra note 8, at 490-91.

18s David \& Miller, supra note 78, at 4282.

156 Commission to Revise, supra note 30 , at 38.

137 See id.

${ }^{188}$ See Bittker, supra note 8, at 3.
}

180 Basing the test on an easily determined purchase price, as opposed to periodic valuations, would make application of the system relatively simple. There is some danger that taxpayers would try to deflate purchase prices. If that became a serious problem, rules similar to those in I.R.C. § 483 and § 1274 (1982 \& West Supp. 1986) (distinguishing purchase price from interest on any unpaid purchase price) could be developed. 
relatively common assets that are clearly for personal use, such as airplanes) once in five years. The valuations would be subject to IRS challenge like other entries on tax returns. Any gain measured over the five-year period will be spread back evenly over the five years, with an interest factor added to adjust the gain upward, and the adjusted gain will be included in income in the current year. ${ }^{160}$

2. For all other items of tangible personal property, the method used for assets excepted from the accrual system would be adopted. This rule would also apply when a taxpayer transferred in a recognition event an item with a purchase price in excess of $\$ 20,000$.

3. Recognition of losses would be governed by the rules of current law, without most of the current rules for nonrecognition. The system would continue to disallow losses on assets not held in a trade or business or as an investment. Nevertheless, to the extent a taxpayer previously recognized a gain on an asset under the system of valuations every five years, the system would allow the taxpayer to deduct these losses. ${ }^{161}$

\section{E. Business Assets}

The discussion so far has focused predominantly on assets that are not used in a trade or business, except for real property. Many of the

160 This is like the rule for assets excepted completely from annual valuation, supra text accompanying notes 38-45. Note that the process of adjusting the gain figure is a surrogate for a more elaborate system. After the total recognized gain is allocated to prior years, the system might require the taxpayer to calculate the tax that would have been paid in that year on that additional income, and then increase the $\operatorname{tax}$ (rather than the gain) by an interest factor to reflect the benefits of the deferral. But that procedure would be more complicated, and would not allow the IRS to develop adjustment tables that could be used by all taxpayers. Nevertheless, the procedure suggested in the text has two disadvantages: on the one hand, it would bunch the income in the year of valuation; on the other hand, it would make the tax liability dependent on the taxpayer's other income in the year, thus leaving room for tax motivation to govern the timing of sales. If this problem were perceived as significant, the proposal could be modified to provide, for example, that the tax rate applied to the recomputed gain would be dependent, in some fashion, on the taxpayer's marginal tax rates in some or all of the prior five years.

${ }^{181}$ This rule for losses will leave a current source of conflict in the Code-the desire of taxpayers to claim that loss assets were held for investment-but should not significantly increase the pressure on the distinction. To the extent the accrual system would result in a larger tax base, and hence lower rates, the pressures would be reduced. On the other hand, eliminating the distinction between capital assets and other assets would increase the pressure, since losses would become more valuable. 
previous proposals for accrual taxation have stopped at this point, restricting themselves to investment assets. ${ }^{162}$ Is it possible to extend the proposal to business assets?

Some business assets, namely those held by corporations, are already included indirectly in the proposal to the extent that the value of corporate stock reflects changes in the value of these assets. Conversely, the proposal does not yet include business assets that are held in sole proprietorships or in pass-through entities whose owners would include changes in the values of their assets on their own tax returns. Thus, a complete proposal requires explicit treatment of business assets. The major categories of business assets are inventories, accounts receivable, depreciable personal property, and intangibles such as good will.

\section{Inventories}

Inventories pose particularly difficult valuation problems because they include many different items, some of which may be obsolete or damaged. Despite this difficulty, the current tax system requires inventories to be valued in order to reflect taxable income correctly. ${ }^{163}$ Under existing law, the two major methods of valuing inventories are cost and the lower of cost and current market price. ${ }^{164}$

Of the two basic methods, allowing valuation at the lower of cost and market price requires some form of valuation every year; thus, this method could carry over into an accrual system. Similarly, the last-in, first-out (LIFO) inventory method, currently an authorized alternative for inventory valuation, ${ }^{168}$ requires a form of valuation at the end of the year in some circumstances. This method allows an even more desirable practice from the perspective of an accrual system. Taxpayers can use the "dollar-value method" of pricing inventories, ${ }^{166}$ under which, in effect, the taxpayer creates a private index for the costs (albeit not the value) of the inventory. Moreover, as authorized by statute, ${ }^{\mathbf{1 6 7}}$ governmental price indices can be used under the LIFO method instead of a taxpayer's own constructed index of costs.

The fact that taxpayers and the IRS have already accepted the

162 See, e.g., David \& Miller, supra note 78, at 4275.

16s See Treas. Reg. § 1.471-1 (1958).

1ot See Treas. Reg. $\S 1.471-2$ (c) (1958). method).

${ }^{105}$ See I.R.G. § 472(a) (1982 \& West Supp. 1986) (authorizing LIFO inventory

${ }^{160}$ See Treas. Reg. \& 1.472-8(a), T.D. 6539, 1961-1 C.B. 167, 168 ("The dollarmethod of valuing LIFO inventories is a method of determining cost by using "baseyear' cost expressed in terms of total dollars rather than the quantity and price of specific goods .....").

167 See I.R.C. § 472(f) (West Supp. 1986). 
possibility of using price indices as a means of measuring inventories suggests that an accrual system could include inventories in a reasonable fashion. The IRS could construct an index that would reflect increases, as well as decreases, in the prices of relevant inventory categories, with the number and precision of the categories dependent on the relative importance of precisely mirroring inventory price movements.

Of course, any rule that depends on categorizing assets raises the specter of significant complexity in its application. This problem is likely to be less severe with inventory than with depreciable property (discussed below) to the extent that inventory, by its nature, comes to the marketplace more often, so that it is easier to determine whether the index used to value it is accurate.

\section{Accounts Receivable}

The current treatment of accounts receivable already reflects principles of accrual taxation to a significant degree. Cash-basis taxpayers include accounts receivable in income on the basis of their value. ${ }^{188}$ Accrual-basis taxpayers must include the face amount of debt owed to them in income, ${ }^{109}$ but that rule is part of a general scheme under which they are also permitted to deduct expenses before the expenses are paid. While the system does not precisely account for fluctuations in the value of accounts receivable, it does permit taxpayers to deduct any accounts receivable that become worthless. ${ }^{170}$ Moreover, to simplify the calculation of debts that become worthless, taxpayers are allowed to create a bad debt reserve, generally based on their prior credit history, which will account for the debts that do become worthless. Thus, accounts receivable are already treated in a way that reflects a concern for a simplified system, but one that looks generally to the value of the accounts receivable from year to year. Particularly in light of the generally short-term nature of accounts receivable, there is no need to revise this structure generally to add additional aspects of accrual taxation. For businesses that deal with unusually long-term accounts receivable, however, the methods suggested above for valuing debt generally could be used. ${ }^{171}$

\section{Depreciable Personal Property}

The introduction of the Accelerated Cost Recovery System

168 See, e.g., Rev. Rul. 79-292, 1979-2 C.B. 287, 289.

169 See id.

170 See I.R.C. § 166(a)(1) (1982).

${ }^{171}$ See supra text accompanying notes 71-72. 
(ACRS) in $1981^{\mathbf{1 7 2}}$ substantially severed the connection between allowed depreciation and actual decreases in the values of assets. ACRS aims to encourage the purchase of assets by allowing deductions that are accelerated compared to actual depreciation. ${ }^{173}$ Although the 1982 tax statute limited ACRS somewhat, ${ }^{174}$ the main thrust of encouraging investment through accelerated depreciation allowances remains.

If Congress adopts an accrual tax system that includes most assets, the ACRS method will clash more frequently with the structure of the system. Because Congress did not base the decision to switch to the ACRS system on an attempt to measure income precisely, Congress would not necessarily eliminate ACRS under an accrual income tax system. Still, ACRS has two motivations behind it: simplicity of valuation and incentive for investment. It may well be wise to decrease the incentive aspect of ACRS under a system that generally expands the tax base and hence allows a reduction in tax rates. Otherwise the benefits of neutrality and equity that can come from an accrual tax system could be obliterated. The 1984 Treasury proposal suggests that it may be possible to develop a single depreciation system that approximates economic depreciation. ${ }^{175}$

\section{Good Will and Other Intangibles}

There is no estimate of the cumulative size of good will and such other intangibles as copyrights and patents. ${ }^{176} \mathrm{Good}$ will, in particular,

172 Economic Recovery Tax Act of 1981, Pub. L. No. 97-34, § 201, 95 Stat. 172, 203-19 (current version at I.R.C. § 168 (West Supp. 1986)).

173 See S. REP. No. 144, 97th Cong., 1st Sess., reprinted in 1981 U.S. CodE Cong. \& AD. News 106.

Reductions in the real value of depreciation deductions diminish the profitability of investment and discourage businesses from replacing old equipment and structures with more modern assets that reflect recent technology. The committee agrees with numerous witnesses who testified that a substantial restructuring of depreciation deductions and the investment tax credit will be an effective way of stimulating capital formation, increasing productivity and improving the nation's competitiveness in international trade. The committee therefore believes that a new capital cost recovery system is required which provides for the more rapid acceleration of cost recovery deductions and maintains or increases the investment tax credit.

Id. at 47, reprinted in 1981 U.S. CoDE CoNG. \& AD. NEws 106, 152.

174 See Tax Equity and Fiscal Responsibility Act of 1982, Pub. L. No. 97-248, $\S 206,96$ Stat. 324, 431 (codified at I.R.C. $\S \S 168(\mathrm{~b})(1), 168(\mathrm{e})(4)$ (West Supp. 1986)).

${ }_{175}$ See 2 Treasury Proposals, supra note 26, at 151-72 (proposing Real Cost Recovery System under which "[n]ew capital cost recovery rules would be established that explicitly account for inflation and .. real economic loss[es] . . . Id. at 157).

${ }^{176}$ See R. GoldSMITH, supra note 47, at 190. 
is quite difficult to value. ${ }^{177}$ Although intangibles are so common that a reasonable proposal for accrual taxation must consider including them, a thoughtful examination leads to the conclusion that all intangibles can be omitted from the system.

\section{a. Human Capacity}

Taxing a business's intangibles largely means taxing potential income; that is, an increase in a business's good will reflects the expectation that the business will be making more money in the future. ${ }^{178}$ Let us consider taxation of a business's potential income after we consider an even more extreme proposal: taxing the increase in an individual's "good will"- the individual's "human capital." For example, when an individual's potential lifetime income is increased by graduation from medical school, should the system immediately tax this increased "value"? Such a result seems dangerous to most of those who have considered it, ${ }^{179}$ because it would tax the medical school graduate who chose not to become a doctor-or, at least, chose not to be a highly compensated doctor.

One commentator who makes such a criticism is Professor Kelman. ${ }^{180} \mathrm{He}$ argues that forcing a beachcomber to work as a doctor (the example is his) to pay taxes "would violate the simple libertarian principle that the state should not require people, directly or indirectly, to engage in particular activities."181 Indeed, absent that awkward principle, "[a]n earnings capacity tax might best achieve the tax system's goal of measuring the inequality of economic power."182

These arguments prove too much, though. Professor Stephan sympathetically examines the possibility of taxing changes in the value of human capital. ${ }^{183}$ Although he does not deal at length with the possible

177 See, e.g., Gregorcich, Amortization of Intangibles: A Reassessment of the Tax Treatment of Purchased Goodwill, 28 TAX LAw. 251 (1975); Note, An Inquiry into the Nature of Goodwill, 53 Colum. L. REv. 660 (1953); Note, Amortization of Intangibles: An Examination of the Tax Treatment of Purchased Goodwill, 81 HaRv. L. Rev. 859 (1968) [hereinafter cited as Note, Amortization]; Comment, Depreciability of Going Concern Value, 122 U. PA. L. REv. 484 (1973).

${ }_{178}$ In the context of debt instruments with a fixed return, that aspect of the change in value has been criticized as double taxation, see Shachar, supra note 11, at 1866-67, although that criticism is inconsistent with the concept of taxing income.

${ }^{179}$ See, e.g., Warren, Would a Consumption Tax Be Fairer Than an Income Tax?, 89 YAl.E L.J. 1081, 1114-15 (1980).

${ }_{180}$ See Kelman, Personal Deductions Revisited: Why They Fit Poorly in an "Ideal" Income Tax and Why They Fit Worse in a Far from Ideal World, 31 STAN.

L. REv. 831, 839 n.23 (1979).

${ }_{181}$ See id. at 842 .

182 Id. at 841.

${ }^{183}$ Stephan, Federal Income Taxation and Human Capital, 70 VA. L. REv. 
objections to a system that forces the beachcomber with a medical degree to work to pay taxes because the medical degree has increased the beachcomber's potential earning capacity, Professor Stephan argues that the law already imposes burdens on persons who prefer not to work. ${ }^{184}$ As examples, he notes that the law may prevent one who breaches an employment contract from accepting comparable employment, that domestic relations courts will not reduce alimony or child support payments when a former spouse chooses to work in a less remunerative way, and that certain jurisdictions may impose property and wealth taxes on unrealized gain, "forcing the taxpayer either to sell his labor or part with some other possession to pay the tax collector."185

In addition, there are many circumstances in which the tax law requires a taxpayer "either to sell his labor or part with some other possession to pay the tax collector," and many circumstances in which the state, through the tax system, "requires persons to engage in particular activities," to the same extent it would require the beachcomber who graduated from medical school to work. ${ }^{186}$ Anyone who earns money and consumes it without setting aside a portion for taxes must earn more money to pay the income tax. ${ }^{187}$ Moreover, someone who exchanges a substantially appreciated asset for other property (not cash), without the protection of one of the nonrecognition provisions of the Code, ${ }^{188}$ must work (or sell some property) to pay tax on the gain. Indeed, the beachcomber who combs beaches successfully will have to choose between selling what the ocean has washed up or engaging in other income-producing activities to pay the tax on the valuable flotsam and jetsam. ${ }^{188}$

1357 (1984).

184 See id. at 1365 n.14.

185 Id.

188 Kelman's rhetoric suggests that the beachcomber would be required to work as a doctor if human capacity were taxed, but that is not so. As long as the beachcomber earned enough, in whatever endeavor, or sold enough property to pay the tax on increased human capacity, the tax system would be satisfied.

${ }^{187}$ As Stephan's discussion of expenditures that enhance human capital makes clear, a portion of the increase in the medical student's earning capacity stems from the expenditure for education, which is currently a nondeductible expenditure. That is, current law requires that an individual whose entire income is spent on subsistence and medical school expenses still pay taxes. See Stephan, supra note 183, at 1373.

188 See, e.g., I.R.C. § 1031 (1982 \& Supp. II 1984) (like-kind exchanges not subject to taxation).

${ }^{189}$ Even if Kelman is correct that there is a "widespread principle that people ought to be taxed only when they voluntarily convert property rights into marketable form," Kelman, supra note 180 , at 842 , a court is unlikely to allow a beachcomber to exclude the value of a found diamond ring, even if it is used to decorate a shack rather than sold in the marketplace. See generally Cesarini v. United States, 296 F. Supp. 3 (N.D. Ohio 1969), affd per curiam, 428 F.2d 812 (6th Cir. 1970) (money found in 
Thus, a rule taxing individuals on the increase in their human capacity would be far from unique in forcing persons who would prefer not to raise more cash to do so, either through the sale of assets or through additional work. If an objection remains, it must stem from some more fundamental (or, perhaps, less rational) source. For example, Professor Warren argues that taxing increases in human capacity could violate a taxpayer's "personhood."180

Such objections generally assume that taxing human capacity would place a severe burden on taxpayers. Stephan points out, however, that a progressive tax system may minimize or eliminate this burden. ${ }^{191}$ If the system treats an increase in human capacity as income and taxes it, the recognition of income will presumably create basis in an asset that may be amortized at least over the taxpayer's expected lifetime. ${ }^{192}$ Because this income will often arise when the individual is not otherwise employed and thus is in a low tax bracket, and because deductions can be taken when the individual is established in a profession and thus is in a higher bracket, the net effect of taxing human capacity might be a benefit to a significant number of taxpayers, assuming the taxpayers can overcome any problem of cash flow. ${ }^{183}$ Thus we are by no means creating a major loophole if we conclude that, for practical reasons, we do not wish to include human capacity in an accrual system.

The above argument assumes that if the system taxes changes in the values of intangibles such as human capacity, it must allow deductions for decreases in value as well as taxing income on increases. Under current law, however, taxpayers cannot take deductions for intangible assets because of the difficulty of estimating the useful lives of such assets with "reasonable accuracy."194 On the other hand, in a system based on periodic accrual of changes in value, if the system includes intangibles, both increases and decreases in the value of these intangibles must be taken into account.

piano is income).

190 Warren, supra note 179 , at 1115 . Contra Stephan, supra note 183 , at $1365-$ 66 n.14.

191 See Stephan, supra note 183, at 1371-72.

192 See 2 B. Bittker, Federal Taxation of Income, Estates and Gifts 41.2.5, at 41-15 (1981) (stating that an asset whose value is included in income takes a basis equal to its fair market value); Sharon v. Commissioner, 66 T.C. 515 (1976), affd, 591 F.2d 1273 (9th Cir. 1978), cert. denied, 442 U.S. 941 (1979) (amortization allowed over taxpayer's lifetime for certain costs of obtaining license to practice law).

183 See Stephan, supra note 183, at 1371-72.

104 See Treas. Reg. \& 1.167(a)-3, T.D. $6452,1960-1$ C.B. 127,128 . The regulation states specifically: "An intangible asset, the useful life of which is not limited, is not subject to the allowance for depreciation. . . . No deduction for depreciation is allowable with respect to goodwill." Id. 


\section{b. Good Will}

Other parts of the proposed accrual tax system already value intangibles, in effect. In particular, valuing the stock of a corporation implicitly takes into account all assets, including good will. In contrast, in the case of a sole proprietorship, a partnership, or other pass-through entity such as an $\mathrm{S}$ corporation, ${ }^{195}$ an intangible must be valued explicitly in order to be included in the system. ${ }^{186}$ If good will and other intangibles are valued only for incorporated businesses, and if valuing them creates a general increase in the income of those businesses, an asymmetric tax treatment would result that could distort investment away from the corporate sector.

Because good will, like human capacity, reflects potential income, it increases in the years before the business receives the income. Moreover, although some decreases in good will may result from unexpected situations (for example, unfavorable publicity about the business), good will ordinarily decreases when a business no longer provides to its customers the services it once did or when the earnings of a company that previously promised substantial increases in earnings level off. Thus a pattern similar to that of human capital may apply also to business good will: the increases in the value of good will may arise in lowincome years, while the decreases in the value of good will may come in profitable years. As long as tax rates remain progressive, the inclusion

193 If we do not eliminate the corporate tax for publicly traded corporations, it would be true for non-S corporations also that the direct tax on the corporation would require an explicit valuation of intangibles.

196 Valuation of such assets is extremely difficult in practice, as is seen in cases where a whole business is sold and some of the purchase price must be allocated to the intangibles. The valuation requirement for intangibles forces business purchasers to exclude from depreciation these intangible, or nondepreciable, assets. See, e.g., Concord Control, Inc. v. Commissioner, 615 F.2d 1153, 1155 (6th Gir. 1980); Northern Natural Gas Co. v. United States, 470 F.2d 1107, 1109 (8th Cir.), cert. denied, 412 U.S. 939 (1973); Winn-Dixie Montgomery, Inc. v. United States, 444 F.2d 677, 686 (5th Cir. 1971); Boe v. Commissioner, 307 F.2d 339, 342-43 (9th Cir. 1962); Computing \& Software, Inc. v. Commissioner, 64 T.C. 223, 235 (1975); Massey-Ferguson, Inc. v. Commissioner, 59 T.C. 220, 225 (1972); see also Dubin, Allocation of Costs to, and Amortization of, Intangibles in Business Acquisitions, 57 TAXES 930 (1979) (discussing various methods of allocating purchase price to good will); Gregorcich, supra note 177 (proposing legislative solutions to handle the amortization of intangibles); Henszey, Going Concern Value After Concord Control, Inc., 61 TAXEs 699 (1983) (examining the "capitalization of earnings method" for establishing going concern value); Krieger, Tax Accounting: Tax Court Explains Going-Concern Valuation, 9 J. CoRP. TAX'N 297, 297-99 (1982) (same); Note, Amortization, supra note 177 (challenging the Code's assumption that purchased good will has an unlimited life); Comment, supra note 177 (criticizing the valuation of intangibles as depreciable assets); $c f$. Des Moines Gas Co. v. City of Des Moines, 238 U.S. 153, 165 (1915) (holding that going concern value, but not good will, should be considered in valuing property for the purpose of rate-making of public service corporations). 
of intangible assets in the accrual system may result in less change in lifetime tax liabilities than might at first be expected.

In light of the major practical difficulties in measuring the value of intangible assets and the relatively insubstantial net effect on revenue of including them in the tax base, the accrual system should omit such intangibles. But does removing direct taxation of good will from the accrual tax system create problems because the system still taxes good will indirectly in the case of corporate stock? I think it is unlikely that someone embarking on a venture that can be carried out either through a corporation or through an unincorporated or other pass-through entity will choose one form over the other as a result of the different tax treatments of good will. Because the precise timing of increases and decreases in good will is too unclear, omitting direct measurement of good will and similar intangibles from the system should not affect many taxpayers' decisions, and is not likely to cause significant or systematic effects.

\section{c. Patents, Trademarks, and Other Intangibles}

The above discussion applies to intangibles that taxpayers cannot buy or sell under any circumstances (human capital) or trade separately from a business (good will). For related reasons, the system should also exclude intangibles such as patents and trademarks, which taxpayers can more easily value, as well as independently purchase and sell.

These other intangible assets, like antiques, are all unique. Moreover, in many of the transactions in which they are purchased and sold, the price is set as a function of actual future revenue, for example, a percentage of future sales, rather than as a fixed dollar amount. ${ }^{197}$ Thus, their valuation is likely to be difficult. Unlike dispositions of real estate and stock of closely held corporations, which also require valuations of unique items, valuation of these intangibles is likely to be an expensive process if required in all cases. ${ }^{108}$ Although their valuation would be less difficult than the valuation of good will and human capi-

197 See, e.g., Cory v. Commissioner, 230 F.2d 941, 942, cert. denied, 352 U.S. 828 (1956) (publishers purchased copyright for percentage of future retail sales).

198 Intangibles may be difficult to value with reasonable accuracy, see B. BITTKER \& J. Eustice, Federal. InCOMe Taxation of Corporations and Shareholders $\S 11.03$, at $11-9$ (4th ed. 1979). Attempts to value intangibles will thus often require more appraisal time and expense, see Bittker, supra note 8, at 3, and are likely to result in prolonged litigation. See, e.g., In re Marriage of Foster, 42 Cal. App. 3d 557, 580, 117 Cal. Rptr. 49, 50 (1974) (valuation must be undertaken on case by case basis); In re Marriage of Lukens, 16 Wash. App. 481, 486, 558 P.2d 279, 282 (1976) (same; also suggests need for expert testimony). 
tal, strong practical arguments advocate removing these other intangibles from the system, too.

If the system excludes such assets, how should gains and losses realized on their exchange be taxed? Once again, the structure provided for assets excepted from annual valuation seems appropriate, with gain taxed on realization and a deferral charge added to account for the failure to tax increases in value when they occurred.

\section{F. Liabilities}

The discussion thus far has focused on the possibility of including the assets a taxpayer owns in an accrual tax system. But liabilities also change in value, a point noted above in the discussion of how to value liabilities in the hands of a creditor. ${ }^{199}$ If a tax system requires valuation of a taxpayer's assets, it should also require valuation of the taxpayer's liabilities by providing for gains when the liabilities decrease in value (that is, the debtor's obligation decreases in value) and allowing for losses when the liabilities increase in value.

Adding liabilities to the accrual system creates several problems. First, a large portion of liabilities relate to assets that the proposed accrual system excludes. According to the data in table 1 , about $47 \%$ of all liabilities consist of home mortgages on owner-occupied nonfarm homes, and an additional $20 \%$ of all liabilities consist of consumer credit. Moreover, some portion of the $18 \%$ of all liabilities that are noncorporate business mortgage debts presumably relates to the residence portions of farms. The importance of including business debt in the accrual tax system should not, however, be underestimated. Liabilities affect not only the tax treatment of individuals but also the tax treatment of pass-through entities such as partnerships and $\mathrm{S}$ corporations.

A second problem involves valuation. An accurate valuation of the debts owed by individuals depends on the particular individual's credit situation, not just the general credit markets. Assessing the former is not easy.

Third, even if the system includes liabilities, policy considerations may dictate different tax treatment for different types of changes in their value. Under current law, when a debtor has a gain on a liability, that is, the debtor satisfies the liability at a discount, the debtor has forgiveness of indebtedness income to which the Code gives special, favorable treatment. ${ }^{200}$ Alternatively, when the debtor has a loss on the 
liability, that is, the debtor retires the debt at a premium, the Code allows the debtor an immediate deduction. ${ }^{201}$

\section{Valuation of Liabilities}

As a first step toward solving the practical problem of valuing a taxpayer's liabilities, the relatively simple approach described above, ${ }^{202}$ which relies on current market interest rates, seems wise. Of course, problems of creditworthiness may arise in valuing an individual's liabilities. The importance of such problems in the valuation process, however, depends on the treatment of income or loss from changes in the value of liabilities.

Unlike income arising from the discharge of indebtedness of taxpayers in difficult financial straits, which the Code exempts from taxation $^{203}$ because of a concern with taxing such persons, ${ }^{204}$ changes in value resulting from fluctuations in the market interest rate evoke no particular policy concerns. These changes can affect any debtor, not merely one in financial difficulty. Thus, it seems appropriate to tax on accrual the gains and losses caused by fluctuations in the market rate of interest, with no amelioration allowed in lieu of income recognition. Income from discharge of indebtedness arising when a debtor in financial straits repays a troubled loan at a discount could still receive special treatment. Indeed, it would be useful to have a mechanism that distinguishes more precisely between forgiveness of indebtedness stemming from interest rate changes (which should always result in recognition of income) and forgiveness stemming from the debtor's financial difficulties. Congress could then more easily fashion favorable treatment tailored to financially troubled taxpayers. ${ }^{205}$

indebtedness income is taxed like any other income. Nevertheless, the Code currently allows (or in some cases requires) taxpayers to reduce tax attributes (most commonly the basis of depreciable assets) rather than recognizing such income. See I.R.C. $\S \S 108$, 1017 (1982 \& Supp. II 1984). When basis is reduced, the taxpayer has lower depreciation deductions in the future, and thus gradually recognizes the income that was deferred when the debt was forgiven.

${ }^{201}$ See Treas. Reg. $\S 1.163-3(c)(1)$ (1968).

202 See supra text accompanying notes 71-72.

203 See I.R.C. \& 108 (1982 \& Supp. II 1984).

204 See S. ReP. No. 1035, 96th Cong., 2d Sess. 9-11, reprinted in 1980 U.S. Code Cong. \& AD. NEws 7017, 7024-26 (reasons for exempting discharge of indebtedness income from taxation include desire to give debtors a fresh start and to give them flexibility to decide how best to achieve that fresh start).

${ }^{203}$ Congress's concern with identifying those taxpayers truly in need of special treatment can be seen in the changes made to the stock-for-debt rules of $\S 108$ in the Tax Reform Act of 1984, Pub. L. No. 98-369, § 59, 98 Stat. 494, 576-77 (codified at I.R.G. $\S 108(e)(10)$ (Supp. II 1984)). While generally tightening the stock-for-debt exception to the debt forgiveness rules, Congress developed an elaborate exception for 
The mechanism for identifying changes in value that result from changes in the market interest rate can be slightly complicated. The system could simply allow the valuation of debt based on a current market rate of interest. This method, however, would probably create gains and losses for many individual taxpayers in the year they incur debt because the interest rate chosen for valuing the indebtedness could not realistically correspond to the individual rates faced by many debtors. ${ }^{206}$ The method suggested above for valuing untraded debt on the asset side $^{207}$ proves superior in this situation as well.

\section{Liabilities Related to Excluded Assets}

The fact that the tax system excludes gains and losses on personal residences does not necessarily imply that gains and losses on associated mortgages should be excluded as well. Indeed, although current law permits taxpayers to defer or ignore gains on residences, ${ }^{208}$ discharge of indebtedness on a home mortgage results in income to the homeowner; moreover, no provision exists for reducing basis rather than recognizing income in those circumstances. ${ }^{209}$

On the other hand, if an accrual system included home mortgages, the number of persons affected by the system would probably increase substantially. The additional administrative burden that the taxation of home mortgage values would put on many taxpayers may itself outweigh the additional benefits in equity, because the decision to buy a

taxpayers in financial difficulty. See I.R.C. $\S 108(e)(10)(C)$ (Supp. II 1984)

${ }^{208}$ For example, if individuals generally borrow at a rate that is $130 \%$ of the prime rate, an interest rate of $130 \%$ of the prime rate could be used to make the necessary valuations. But that decision would create losses for taxpayers in financial difficulty, who borrow at twice prime (and whose debt, therefore, would appear to have increased in value because it had an interest rate well over the rate used for measuring debt), whereas very wealthy individuals, who borrow at lower rates, would have gains. Moreover, one would have to provide special rules for secured debt and other special situations. Note that the Code already deals with income tax problems created by lowinterest loans. See I.R.C. $§ 7872$ (West Supp. 1986).

${ }^{207}$ See supra text accompanying notes 71-73.

${ }^{208}$ See I.R.C. $\S \S 121,1034$ (1982 \& Supp. II 1984).

${ }^{200}$ See Rev. Rul. 82-202, 1982-2 C.B. 35 (taxpayer had income after prepaying mortgage for less than balance due). There has been at least one failed attempt to enact legislation allowing basis reduction for gains on mortgage repayments. The Mortgage Debt Forgiveness Tax Act of 1983, S. 1147, 98th Cong., 1st Sess., 129 Cong. REC. S5225 (daily ed. April 26, 1983), was introduced by Senators Danforth, Tsongas, Symms, and Thurmond in 1983, and hearings were held on May 27, 1983. See 198384 Miscellaneous Tax Bills, II: Hearing before the Subcomm. on Taxation and Debt Management of the Senate Comm. on Finance, 98th Cong., 1st Sess. 18-20 (1983). Because the gain ultimately recognized when a residence is sold might go untaxed under I.R.C $\S \S 121,1034$ (1982 \& Supp. II 1984), the net effect of this legislation would have been to eliminate from tax much of the income on discharge of personal mortgage debt. 
home, and thus to borrow for that purpose, is much more a consumption decision than an investment decision. ${ }^{210}$ Moreover, as interest rates rise, thus decreasing the value of a fixed rate liability (and increasing the homeowner's net worth), the value of real estate is likely to fall. Since we do not take account of the change in value of the home, it is probably wise not to take account of the change in value of the mortgage.

The system should also exclude consumer credit. Including consumer credit would require many persons who could otherwise ignore such concerns to perform calculations of gain and loss. In addition, because consumer debt is likely to be relatively short-term debt, measuring annual changes in its value would yield little gain.

The system need not exclude business debt. If the system indirectly includes changes in the value of debt on the asset side through a tax on the owners of these entities, there is no reason to exclude such changes on the liability side, at least in the business context in which no major administrative or political problems would arise from their inclusion.

\section{Exclusion of Other Liabilities}

Should the accrual system exclude any other liabilities? Three other categories deserve consideration. First, the system might exclude small loans. If the principal of a loan is below $\$ 1000$, for example, the administrative cost of keeping it on the system may outweigh any benefit. Second, the system could exclude loans with adjustable interest rates, on the theory that because such loans already account for changes in the market rate of interest, the system should disregard any additional market effect on the value of such loans. Third, the system could exclude loans with short maturities. Such loans probably generate little gain or loss except to the extent already addressed by the Code provision for low-interest loans. ${ }^{211}$

\section{The Problem of Differing Treatments of Liabilities}

Should there be concern that some liabilities will be in the system and others will not? This Article has noted repeatedly that when some items are in the system and similar items are not, a substantial possibility always exists that tax-motivated planning will result. Unlike the comparable situation on the asset side, however, the issue here is not so

210 This argument is undercut somewhat to the extent that the system adopts the valuation methods discussed supra, text accompanying notes 71-73:

${ }^{211}$ See I.R.C. $\S 7872$ (West Supp. 1986). 
serious. While persons normally invest in assets in the hope of appreciation, they rarely assume liabilities with an eye toward their (taxbased) value.

Moreover, unlike eliminating the deduction for payment of interest on debt, ${ }^{212}$ which will generally increase taxable income, the inclusion of a debt in the accrual system is not necessarily a benefit or a detriment-it depends on the level of interest rates after the debt is incurred. Thus, no major inducements for disruptive tax planning would result from excluding some, but not all, liabilities from this system. This argument should not, however, induce us to exclude additional items from the system. To the extent we want to measure income accurately in order to allocate tax liabilities fairly among taxpayers, the more items we value, the better off we are.

\section{The Liquidity Problem}

After valuation, the second major obstacle to adopting an accrual tax system is taxpayer illiquidity: should the tax system require a person to pay a tax on the appreciation of an asset when the tax may require the person to sell the asset? Because the proposed accrual system excludes hard-to-value securities and most collectibles, illiquidity poses a problem primarily for taxpayers holding real property that the system includes. Some securities may also create practical problems of illiquidity, since the market for some stocks may be sufficient to establish a price but too thin to allow an owner to dispose easily of a significant number of shares.

Although the liquidity problem certainly deserves careful examination, several facts suggest that the problem may not be great. First, under the system proposed here, taxpayers would face a less severe liquidity problem than taxpayers with illiquid estates currently face under the estate tax. The tax rates of the estate tax may exceed the highest marginal income tax rate, ${ }^{213}$ and the estate tax applies to the full value of an asset, rather than the annual increase in the asset's value as under an accrual system. Second, the accrual system would expand the base for income taxation by a per-year average of more than $20 \% .{ }^{214}$ A larger base enables a reduction in income tax rates

${ }^{212}$ Prior proposals have not been uniform in their treatment of interest. Compare Presiden'T's TAX Proposals, supra note 3, at 104-05 (preserving deductibility of interest) and BluferRINTs, supra note 11, at 7 (same) with CoMMISSION TO REvise, supra note 30, at 23-24 (suggesting elimination of interest deduction).

${ }^{213}$ Compare I.R.C. $\S 1$ (1982 \& Supp. II 1984) (income tax rates) with id. $\S 2001$ (estate tax rates).

214 See infra Appendix B. 
without loss of revenue. This decreases the likelihood that a taxpayer with a gain on illiquid assets would incur a substantial new tax liability under the accrual system. At the very least, taxpayers should not have a liquidity problem to the extent that the tax on their accrued gains simply brings their tax liabilities up to the level that they would have paid prior to this tax reduction.

Although commentators often cite liquidity as a major problem in developing an accrual tax system, ${ }^{215}$ prior proposals have not considered it at length. For example, neither the Twentieth Century Fund ${ }^{\mathbf{2 1 6}}$ nor the David and Miller proposal ${ }^{217}$ explicitly discusses the liquidity problem. The Commission to Revise the Tax Structure recognizes the liquidity problem, ${ }^{218}$ but suggests only the possibility of deferring tax payments, with interest, in the case of "large accrued gains from growth corporations."218

Several commentators who would restrict the accrual system to securities of various types do consider the problem of liquidity. Slawson, in his proposal limited to publicly held stock, shows little sympathy for shareholders who must sell stock in order to pay a tax liability. ${ }^{220} \mathrm{He}$ concludes that forced sales pose no problem even for a controlling shareholder. ${ }^{221}$ Alternatively, a Note that proposes taxing appreciation of marketable securities considers a system allowing a tax liability to

${ }^{215}$ See, e.g., Commission to Revise, supra note 30, at 40; M. David, supra note 8 , at 184; Blum, supra note 7 , at 255 (discussing liquidity problems in taxing unrealized capital gains). But cf. Shoup, supra note 8, at 99 (people would plan around liquidity problems if they knew accrued gains would be taxed); General Tax Reform: Panel Discussion Before the House Comm. on Ways and Means, 93d Cong., 1st Sess. 284, 285 (1973) (statement of Prof. Richard A. Musgrave) ("The frequently raised objection that taxation of gains not realized by sale is unfair because the taxpayer has no cash with which to pay his tax poses a valid concern only where family farms or enterprises are involved.").

216 The Fund's proposal suggests alternatives to accrual taxation that would tax gains only when recognized and provides for various types of averaging of the recognized gains. See Twentietr CENTURy Fund, supra note 8, at 480-82, 491. These alternatives are designed to solve the possible constitutional problem of an accrual tax system and reflect no concern for liquidity problems as such.

217 See David \& Miller, supra note 78.

218 See Commission to Revise, supra note 30 , at 17, 40. Its report states, "The Commission is aware of the economic problem of paying a tax in money on unrealized gains that, in a sense, are only paper profits." Id. at 17.

210 Id. at 40.

220 See Slawson, supra note 79, at 646-47 ("It is immaterial that [a shareholder] might have preferred not to sell, even at an appreciated price. Tax assessments limit everyone's ability to invest, and there is nothing in the situation of the public shareholder to justify giving him any special consideration.").

${ }^{221}$ See id. at 649 ("A controlling shareholder . . . . who felt compelled to sell some of his shares to raise tax money . . . would fail to receive the additional value, or 'premium,' that control stock may command. . . . [But] the loss involved would be minimal or nonexistent.") (footnotes omitted). 
accrue, unpaid, while accumulating interest. The liability would not be payable until the taxpayer sold the stock. ${ }^{222}$

Solutions to the liquidity problem that provide for an interestbearing tax liability date back to Professor Vickrey's elegant proposal for cumulative lifetime averaging of income. ${ }^{223}$ Under that proposal, taxpayers may deduct their investments whenever they please. The proposal can allow liberal rules for deductions because it offers a compensating benefit to taxpayers who pay their taxes in earlier years. The compensating benefit comes in the form of a special tax account maintained for each taxpayer into which the taxpayer deposits all tax payments. The account earns imputed interest, which is included in income, but that interest counts as part of the taxpayer's tax payment for the year. ${ }^{224}$ If the taxpayer accelerates a tax payment, surrendering funds early in the taxpayer's lifetime, the interest earned on the payment reduces the obligation to make tax payments in the future. As a result, when a taxpayer chooses to accelerate a deduction, the effect is the same as a loan from the government. Under current law, the loan resulting from an accelerated deduction bears no interest. ${ }^{225}$ Under Professor Vickrey's proposal, however, the borrower must pay interest.

Although Professor Vickrey himself notes a number of technical problems that would arise in connection with the cumulative averaging proposal, ${ }^{226}$ one problem that he and other advocates of tax accrual with interest have ignored is the fact that cumulative averaging would make the government a willing lender to anyone who wished to borrow without providing meaningful credit control. Not only would the IRS have difficulty choosing a proper interest rate for each borrower, but also many taxpayers who should no longer be extended credit would borrow. Of course, such borrowings already occur under current law: taxpayers can enter into tax shelter arrangements, which defer income and earn no interest for the government.

Even when no interest is charged, there is evidence that many taxpayers ignore the implicit debt that they are carrying. ${ }^{227}$ If tax liabili-

${ }^{222}$ See Note, supra note 79 , at 872 n.65. at 737.

${ }^{223}$ For a relatively recent statement of the proposal, see Vickrey, supra note 19 ,

${ }^{224}$ For example, assume a taxpayer pays $\$ 1,000$ of tax in Year 1. If a $10 \%$ interest rate is used, then in Year 2, the taxpayer will be deemed to have $\$ 100$ of income and $\$ 100$ of tax paid.

${ }_{225}$ See M. Graftz, supra note 10, at 341-42.

${ }^{226}$ See Vickrey, supra note 19, at 745-47. Most troublesome, in his view, would appear to be the problems raised by changes in marital or jurisdictional status.

${ }^{227}$ For example, this problem arose in the case of taxpayers who engaged in commodity tax straddles. When Congress closed that method of deferral in 1981, see Economic Recovery Tax $\Lambda$ ct of 1981 , Pub. L. No. 97-34, $\S \S 501-08,95$ Stat. 172, 323-33, 
ties were accrued with explicit interest, so that a taxpayer's debt grew over time, we could expect taxpayers to lack the money to pay the debt in many more circumstances. ${ }^{228}$ For this reason, this proposal has attempted to limit those cases in which taxpayers could postpone tax liabilities rather than pay them immediately.

To what extent must the accrual system expand allowed deferral of tax liabilities to take account of liquidity problems? A recent survey of consumer finances by the Federal Reserve Board and other federal agencies $^{22 \theta}$ provides useful data for calculating liquidity. In analyzing this data, I have disregarded assets that the accrual system described in this paper would never require individuals to value and pay tax on, such as personal residences and retirement savings. Table 2 shows the liquidity of different income groups as calculated from the survey data. $^{230}$ Of the total population, $2.28 \%$ hold only nonliquid assets,

the problems that arose for those who finally had to pay their tax debts led to special legislation to ease the burden of the tax payments. See id. at $\S 509,95$ Stat. at 333. The legislation allowed the tax on what was, in effect, accumulated deferred income to be paid in installments over as many as five years. As of April 15, 1982, the due date of 1981 tax returns, that liability did accrue interest.

${ }^{228}$ Of course, creating the liability in the context of appreciating assets is less severe a problem than under Vickrey's proposal because the appreciating asset itself provides some security. Moreover, any decrease in its value will produce a tax benefit; however, the increased value may not cover the interest obligation that is accruing, nor is there any check on the possibility that taxpayers might use the property as explicit security for other loans. Unless the bankruptcy laws were changed in light of changed tax laws, a secured creditor would have priority over the tax collector in receiving the proceeds of the sale of the property. See 11 U.S.C. $\$ 726$ (Supp. II 1984) (setting out order of priority for final distributions in bankruptcy).

An additional problem with Vickrey's cumulative averaging might be noted. Under his proposal prior years' tax payments are cumulated in an account on which the taxpayer receives interest. This "interest" becomes part of the taxpayer's income for the year, but it is also included as a payment of tax for the year. Vickrey's tax tables are constructed on the premise that individuals "should" be taxed as if their incomes have been earned ratably throughout their working careers. For the best description of the details of the plan, see W. Vickrey, AgENDA For Progressive TAXation 41722 (1947). The result is that when a taxpayer's income decreases, the taxpayer receives a refund; most taxpayers who retire would thus receive refunds through their retirement years. One effect of such a tax system is likely to be a major shift of the tax burden from older to younger taxpayers. This shift may be politically possible only if older taxpayers receive a comparable detriment, such as the abolition of the Social Security system as we know it.

${ }_{229}$ For a description of the survey, see Avery, Elliehausen \& Canner, Survey of Consumer Finances, 1983, 70 FED. Reserve BULL. 679 (1984). Use of this survey data probably exaggerates the liquidity problem, since "sample surveys of financial assets generally yield figures lower than those derived from macroeconomic data." $\mathbf{R}$. GoldsMrTH, supra note 47 , at 117 n.1.

${ }^{230}$ The values in table 2 were calculated from the responses to the survey, copies of which were acquired from the Federal Reserve. See Avery, Elliehausen \& Canner, supra note 229 , at 690 n.13. For purposes of this calculation, liquid assets include checking accounts, certificates of deposit, money market accounts, pássbook savings accounts, federal and corporate bonds, traded securities, and gold and silver bullion. Illiq- 
while the liquid assets held by an additional $7.69 \%$ of the population comprise less than $5 \%$ of these individuals' total assets. For higher percentages of liquidity, the percentage of families with liquidity problems drops off. At first glance, the fact that about $10 \%$ of the population have less than $5 \%$ liquidity seems troubling; however, a more careful examination of the responses of 357 families who fit into that category $^{231}$ reveals that, for many of them, no serious problems are likely to arise.

uid assets include notes, land contracts, real estate (including other residential units in a multi-family structure in which the respondent lives), closely-held businesses, interests in trusts, surrender value of life insurance policies, and miscellaneous assets (including works of art and other collectibles). While the surrender value of life insurance policies is liquid in the sense that it would be easy to convert it into cash, it seemed unlikely that one would want taxpayers to surrender their life insurance policies to pay their income taxes.

${ }_{231}$ Twenty-four of the respondents with less than 5\% liquidity gave no information about income, and they have been disregarded for purposes of this analysis. 


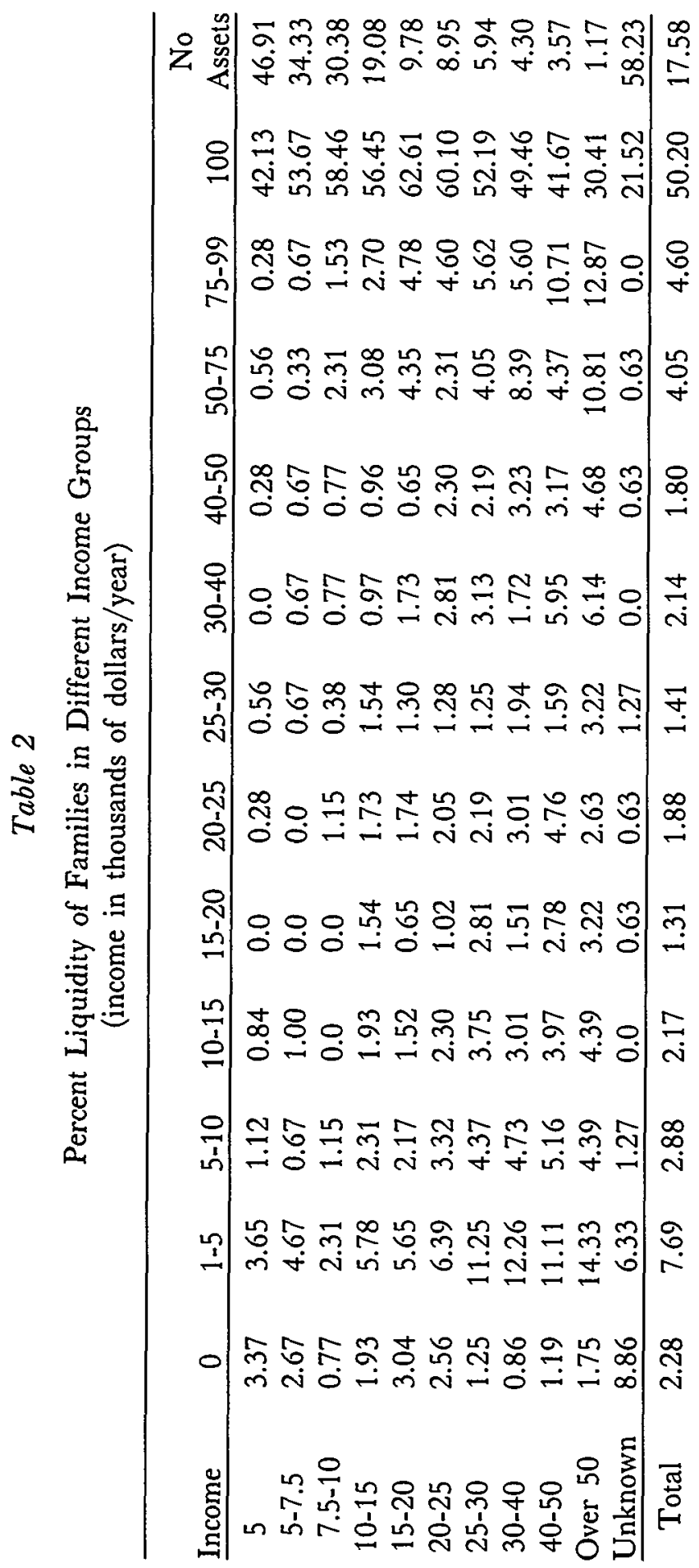


Within this category of families holding a large percentage of illiquid assets fall several groups of individuals who would not be expected to have serious liquidity problems:

1. Individuals who hold relatively few assets. Consider a taxpayer with $\$ 5,000$ of income and $\$ 10,000$ of illiquid assets. On average, assets increase in value in one year by about $4.5 \% .{ }^{232}$ A $4.5 \%$ increase in this person's illiquid assets would result in $\$ 450$ of additional income. One would expect the individual's tax rate to be about $12.5 \%,{ }^{233}$ which would result in a tax of $\$ 56.25$ on the increased value, about $1.1 \%$ of the individual's income and only about $0.5 \%$ of the total value of the assets. Thus, anyone with income of $\$ 5,000$ who owns $\$ 10,000$ of illiquid assets would probably not have serious liquidity problems under the proposal. In general, I assume that persons with income below $\$ 10,000$ could pay up to $2 \%$ of their incomes as additional taxes; those with $\$ 10,000$ to $\$ 50,000$ of income could pay up to $4 \%$; and those with over $\$ 50,000$ of income could pay up to $6 \%$.

2. Individuals who have illiquid assets that do not vary greatly in value. If illiquid assets are not particularly volatile, a taxpayer will not normally experience problems in paying a tax on the changes in value of such assets. The illiquid assets that could be considered not volatile include notes, land contracts, and insurance policies. ${ }^{234}$

3. Individuals who have an interest in a closely held business comprising their major illiquid asset. The data alone do not tell us whether persons in this group will have liquidity problems. Two facts may result in their illiquidity not being of concern. First, to the extent their closely held businesses are incorporated, gains and losses will be taxed only on realization. ${ }^{235}$ Second, someone with a controlling interest in a closely held corporation will have access to the liquid assets held in that entity. Thus, persons with substantial

232 See infra Appendix B.

${ }^{233}$ See infra Appendix B table (tax rates).

234 The category that includes insurance policies also includes other assets, such as interests in trust, but it seems unlikely that those assets would change the conclusion in the text for many taxpayers.

233 See supra text accompanying note 93. To the extent the corporations are $\mathrm{S}$ corporations, the liquidity problems their shareholders face should be little different from the liquidity problems they currently face. Under existing law, S corporation shareholders are taxed on the income of the corporation whether or not the corporation makes any distribution to the shareholders. 
business assets may not have liquidity problems.

An examination of the data in light of these further considerations reveals that the problem of liquidity decreases substantially. Table C-2 of Appendix $C$ shows that, if one assumes a $4.5 \%$ annual appreciation rate for assets and disregards persons in the three categories above, less than $0.9 \%$ of the population has liquidity problems. Alternatively, under the liberal assumption of $13 \%$ appreciation-a rate higher than the appreciation in any year in the period 1961-1984 ${ }^{236}$ - only about $2 \%$ of the population have liquidity problems. ${ }^{237}$ Even under the assumption of $25 \%$ appreciation, which is almost twice the appreciation for any year in the period 1961 to 1984, persons with potential liquidity problems number only about $3.25 \%$. $^{238}$

Should tax policymakers worry about such persons? Because people with liquidity problems include only those holding investment or business assets that (at least assuming a $4.5 \%$ rate of appreciation) substantially exceed their incomes, ${ }^{239}$ one might conclude that those people should pay a somewhat greater percentage of their income in taxes in order to solve their liquidity problems. Moreover, those persons should be in a very good position to borrow in order to pay their taxes in a year of significant increase in the value of their assets. About two-thirds of the persons identified as having liquidity problems in table C-2 (those with over $\$ 20,000$ of income) have over $\$ 200,000$ of assets. ${ }^{240}$ Unless these persons have already fully encumbered their assets, they should be able to borrow whatever they need to pay taxes before they sell the property. Finally, if taxpayers know that they will have to pay a tax on appreciation in value, not just on realization, they are likely to change their portfolios to take that tax scheme into account.

This ability of taxpayers to respond to the tax system is the lesson of the estate tax, under which similar liquidity problems potentially arise. Professor James D. Smith ${ }^{241}$ and the staff of the Iowa Law Review $^{\mathbf{2 4 2}}$ attempt to measure liquidity in connection with the estate tax. Analyzing data from estate tax returns filed in 1973, Professor Smith

B.

${ }^{238}$ For a discussion of the calculation of annual appreciation, see infra Appendix

237 See infra Appendix C, table C-3.

238 See infra Appendix C, table C-4.

239 See infra Appendix C, table C-1.

240 See id.

241 See Federal Estate and Gift Taxes, Public Hearings and Panel Discussions Before the House Comm. on Ways and Means, 94th Cong., 2d Sess. 1309-32 (1976) (testimony of James D. Smith) [hereinafter cited as Estate Tax Hearings].

${ }_{242}$ See Contemporary Studies Project: Large Farm Estate Planning and Probate in Iowa, 59 IowA L. Rev. 794, 928-30, \& apps. E, H, O, P \& S (1974) [hereinafter cited as Iowa Study]. 
calculates the ratio of the estate tax plus costs on the one hand, to liquid assets minus debts on the other. He uses this measure to indicate the extent to which estates might be forced to sell illiquid assets to pay the estate tax. The data showed that, for all estates, only $5.8 \%$ had ratios of one or more; that is, for only $5.8 \%$ of all estates would taxpayers find it necessary to sell illiquid assets to pay the estate tax. ${ }^{\mathbf{2 4 3}}$

Professor Smith performs a separate calculation for estates that contained some farm or noncorporate business assets. ${ }^{244}$ Of those estates, $12.1 \%$ had ratios of tax plus costs to liquid assets minus debts totaling one or more, with an additional $4.2 \%$ having ratios between three-quarters and one. ${ }^{245}$ Thus, according to these figures, about $16 \%$ of estates with farm or noncorporate property face potential liquidity problems.

The effect of a tax system that requires tax payments even from persons holding illiquid assets can be seen by comparing Professor Smith's data with data from the study of Iowa farms conducted by the Iowa Law Review. The Iowa study indicated that an average of $25 \%$ of the gross estates of farmers who had died consisted of liquid assets, while for living farmers the comparable figure was $9.5 \% .{ }^{248}$ As the study concludes, this difference may well result from actions taken by farmers (or their attorneys) prior to death in order to facilitate payment of the estate tax. ${ }^{247}$ Thus, taxpayers seem quite capable of adjusting their financial affairs to meet tax needs.

How should the accrual system handle those taxpayers who would still encounter liquidity problems? Even under current law, despite the

243 See Estate Tax Hearings, supra note 241 , at 1320 table 6 . Smith made the same calculation excluding those estates that included in the gross estate assets that the decedent had transferred within three years of death, see I.R.C. $\$ 2035$ (1982). Only $4.4 \%$ of the estates in that group had ratios of one or more. See Estate Tax Hearings, supra note 241 , at 1321 table 7.

244 See Estate Tax Hearings, supra note 241, at 1321, text accompanying table 6. Professor Smith emphasized that category of assets because he had been directed to consider "the problem of liquidity in the estates of decedents, particularly those with small businesses, business and farm assets." Id . at 1309. He did not attempt to distinguish stock of closely held corporations from other corporate stock, and thus no investigation was made of the liquidity problems of owners of closely held corporations. According to Professor Smith's data, 2.3\% of the gross assets of all estates consisted of farm and noncorporate business assets, as compared to $22.6 \%$ of gross assets for real estate, the largest category of nonliquid assets. See id. at 1320 table 5. Presumably, the high percentage for real estate reflects, to a significant degree, owner-occupied homes included in estates.

245 See id. at 1320 table 6 . The comparable percentages when estates with lifetime transfers are excluded are $11.6 \%$ and $4.1 \%$. See id. at 1321 table 7.

${ }^{248}$ See Iowa Study, supra note 242, at 929.

247 See id. at 930. 
various withholding rules that promote current payment of taxes, ${ }^{248}$ taxpayers may have insufficient funds to pay their tax liabilities. When that happens, the taxpayer must work out an arrangement with the IRS to provide for the prompt payment of the tax liability. ${ }^{248}$

If, however, prudent policy requires an accrual system that does not create liquidity problems for any taxpayers, other approaches could be devised. For example, we could adapt the rule that grants an estate an extension of time to pay the estate tax when the estate consists largely of an interest in a closely held business. ${ }^{250}$ This solution, though, assumes that preference should be given to taxpayers in such situations because the income from the illiquid assets in question cannot cover the relatively high estate tax, which applies to the full value of those assets. In contrast, because the accrual system taxes only changes in value, it need not show similar sympathy.

The accrual tax system should not encourage taxpayers to create liquidity problems; otherwise, it would simply develop a new goal for tax lawyers. On the other hand, the accrual system should not, as an initial matter, penalize taxpayers with liquidity problems. One compromise would require taxpayers to pay at least a certain percentage of their income, excluding their accrued gains, as a tax on those accrued gains. For those who would have tax liabilities exceeding that percentage, and who could demonstrate that liquidity problems existed for them, ${ }^{251}$ the system might have to provide for interest-bearing tax liabilities. To discourage persons from borrowing from the government at rates that might well be unavailable to them in the private debt market, the interest rate should be set at a level that would prove unattractive to most taxpayers. After all, they could borrow from someone other than the government to pay their taxes. For those who would qualify for this deferred payment scheme, the IRS could make individual arrangements that would allow it to monitor repayments.

\section{EXtension of THE Accrual System to ACCOUNT FOR INFLATION}

The previous two sections have developed a proposal for an accrual tax system that addresses the valuation and liquidity problems.

${ }^{248}$ See, e.g., I.R.C. § 3402(a) (1982).

${ }^{240}$ See, e.g. I.R.C. $\$ 6161$ (1982).

250 See id. at $\S 6166$.

${ }^{251}$ The Code includes a limited test of liquidity for purposes of deferring payment of the estate tax, see id., and such a test has been suggested as a requirement for any more general estate tax deferral provision. See Gutman, Reforming Federal Wealth Transfer Taxes After ERTA, 69 VA. L. REv. 1183, 1270 (1983). 
An extension of the proposed system could give rise to a major benefit beyond those inherent in the system proposed thus far. A tax system that taxes changes in the value of assets (whether on accrual or realization) but does not account for inflation imposes an "inflation tax" on taxpayers whose assets appreciate in value; that is, the system taxes the increase in an asset's value due to inflation as well as increases due to other causes. Because an accrual system would already require taxpayers to record the value of assets each year, taxpayers could relatively easily adjust the income earned on those assets for inflation. In order to make such an adjustment, a taxpayer would simply multiply the sum of the values of all assets at the end of the previous year by the appropriate inflation rate. ${ }^{252}$ The taxpayer would then subtract that amount (or some percentage of that amount) from income.

Of course, like other proposals that have been made to adjust for inflation, ${ }^{253}$ the accrual system would have to adjust liabilities as well as assets, thus creating more income for debtor taxpayers in times of inflation. Because taxpayers would already have to compute many asset and liability values, they could make an inflation adjustment for debt simply by netting the value of their debt against the value of their total assets before making the inflation adjustment. The problem with this method, however, is that the system does not include all assets and liabilities. In particular, the proposed accrual system excludes mortgages and consumer debt, which comprise about two-thirds of all debt held by individuals. $^{254}$

Despite the problem posed by debt excluded from the accrual system, adjustments for inflation need not, and should not, ignore liabilities. From a debtor taxpayer's perspective, adjusting the value of debt for inflation would decrease the deductions the taxpayer could take either on the interest owed on the debt or on the inflation portion of gains on assets; that is, the inflation adjustment for debt, unlike the adjustment for assets, would increase taxable income.

The system would not have to force a taxpayer to value debt in order to take this inflation effect into account. Instead, the system could allow the taxpayer to deduct interest payments based on the real rate of

${ }^{252}$ There is controversy over which inflation rate to use. See, e.g., Aaron, Inflation and the Income Tax: An Introduction, in INFLATION AND THE INCOME TAX 1, 15-16 (H. Aaron ed. 1976) (discussing various inflation indices and their limitations). Using the GNP deflator, I calculate that allowing inflation adjustments will decrease the tax base by about $20 \%$. See infra Appendix B.

${ }^{25 s}$ See, e.g., Brinner, Inflation and the Definition of Taxable Personal Income, in INFLATION AND THE INCOME TAX, supra note 252, at 121, 131-32 (advocating recognition of inflation gains and losses with respect to personal debt and savings).

254 See table 1, supra pp. 1125-26. 
interest rather than the nominal rate. The real interest rate is simply the stated, or nominal, rate minus the inflation rate. A deduction based on the real interest rate would effectively reflect an inflation adjustment on the value of the debt. ${ }^{255}$ Thus, even if a liability would be excluded from the accrual tax system for purposes of valuation, the interest paid on that liability should still be adjusted for inflation.

\section{Transition and Implementation Problems}

No tax reform proposal should avoid discussing how best to change from the old system to the new one, for the costs of transition and implementation may-when combined with the other costs of the new system-outweigh the new system's benefits. Other advocates of an accrual tax system have considered how to effect a relatively smooth transition to such a system. Generally, they propose taxing only gains and losses accrued after the new system becomes effective, although they vary in their methods to deal with any gain or loss that accrued before that time.

David and Miller, ${ }^{256}$ for example, offer a number of possibilities: taxing accrued gains as of the date of enactment at the favorable capital gains rates rather than the ordinary income rates that would apply after that date; spreading forward for ten years the tax on the previously accrued gains with forgiveness of further taxes due if the taxpayer dies before the end of the ten years; or taxing only a percentage of the previously accrued gains, reflecting the percentage of gains that taxpayers ordinarily recognize in a given year. These approaches attempt to encourage taxpayers to declare the correct value in the current year, by making the resulting tax low, so that taxpayers can avoid a higher tax once the accrual tax is fully implemented. David and Miller also raise the possibility of phasing in the full taxation of accrued capital gains by

${ }^{255}$ For example, in a world with $10 \%$ inflation, a taxpayer with an asset worth $\$ 1000$ at the beginning of the year and $\$ 1200$ at the end of the year and a $\$ 100$ debt with a $\$ 15$ annual interest payment will pay taxes on $\$ 95$ of income regardless of whether the debt or the interest is adjusted for inflation.

If the debt is adjusted, its face value is netted against the $\$ 1000$ asset value to give a preadjustment value of $\$ 900$, see supra text accompanying note 252 . Multiplying this by a $10 \%$ inflation figure gives a $\$ 90$ inflation offset against the $\$ 200$ rise in asset value. The taxpayer's taxable income is $\$ 110$. Once the $\$ 15$ interest deduction is taken, tax is owed on $\$ 95$.

If the interest is adjusted, the taxpayer can deduct only $\$ 5$ of interest, since the real interest rate on the debt is $5 \%$. The inflation offset on the asset, without netting out the debt, is $\$ 100(\$ 1000 \times 10 \%)$, which is subtracted from the $\$ 200$ of income from the rise in value of the asset to give $\$ 100$ of taxable income. Once the $\$ 5$ interest deduction is taken, tax is again owed on $\$ 95$.

${ }^{256}$ See David \& Miller, supra note 78 , at 4286. 
allowing progressively smaller deductions for them over a three year transition period.

The Commission to Revise the Tax Structure deals summarily with the transition issue in its proposal. It simply notes that prior gains could be excluded from the system, without indicating how or when these gains would be treated. The Commission also suggests, like David and Miller, that if prior gains were taxed, the tax might be spread forward to avoid a major burden on taxpayers during the transition. ${ }^{257}$

One of the proposals to tax only stock appreciation on an accrual basis suggests several possible transition strategies. For example, the system could tax the difference between basis and transition year fair market value in the year the taxpayer sells or exchanges stock. ${ }^{258}$ Another alternative would allow taxpayers to elect to spread the tax on some percentage, say $50 \%$, of the pre-transition accrued gain over a period of perhaps five years after the accrual system is introduced. This alternative would allow the taxpayer to increase basis by $20 \%$ of the gain in each year, so that after five years a full basis step-up would be achieved although only half the gain would be taxed. ${ }^{259}$ This approach would encourage taxpayers to go on the accrual system. Yet another alternative would accrue the tax liability, with interest, and would require taxpayers to pay the tax only upon sale or other transfer. ${ }^{260}$

These transition rules aim in part to prevent changes in the tax law from frustrating expectations. Professor Graetz argues that such a goal is inappropriate. ${ }^{261}$ Policymakers who remain concerned with frustrating expectations may nevertheless conclude that no remedial action is necessary, because immediate transition to an accrual system should not be disruptive. The system proposed in this Article covers most assets (the major exceptions are homes and consumer durables) either directly, or through a mechanism (taxation of gain on realization and adjustments for deferral) intended to yield results substantially equivalent to accrual. As a result, the relative advantages of investing in different types of assets may be affected very little. While homes and consumer durables might at first appear more attractive than they are under current law, it must be kept in mind once again that expanding the base for taxation under the proposed system would permit a de-

${ }^{257}$ See Commission to Revise, supra note 30 , at 40 .

258 See Note, supra note 79, at 873.

250 See id. at 873 n.72.

260 See id. at 872 n.65.

${ }^{261}$ See Graetz, Legal Transitions: The Case of Retroactivity in Income Tax Revision, 126 U. PA. L. REv. 47, 63-87 (1977) (arguing that the effective date of new legislation should not be delayed for either fairness or efficiency reasons). 
crease in tax rates generally. ${ }^{202}$ With lower rates, the advantage under current law of investing in consumption items would lose some of its value. Moreover, because the gains on owner-occupied houses and consumer durables constitute a very small part of the present tax base ${ }^{263}$ the change to an accrual system, which excludes these assets, would probably not frustrate taxpayers' expectations very much.

Perhaps a more significant effect of moving to an accrual tax system would be the change that could occur in the relative values of assets that produce recognized gain on a relatively short-term basis compared to those that usually represent long-term investment. Assets currently viewed as short-term investments should become relatively more attractive once the accrual system taxes increases in the values of all assets yearly. Nevertheless, the major category of assets that produces disproportionate amounts ${ }^{264}$ of short-term gains and losses, futures contracts

262 See infra Appendix B.

${ }^{263}$ See supra notes $116-20$ and accompanying text; supra text accompanying notes 152-53; infra Appendix A, table A-5.

${ }^{264}$ The extent to which futures contracts produce disproportionate amounts of short-term gains and losses can be seen from the following table, which is derived from 1973 GapITAL GaINS REPORT, supra note 129, at 69-96 table 5. The precise category that I have labeled "futures contracts" is what the IRS report calls "Commodities, Including Futures Contracts." Nevertheless, the definition of that category indicates that, in the case of commodities themselves, "[s]ales resulted from an obligation to buy or sell a fixed quantity of a commodity on a specific date at a fixed price." Id. at 5. Thus, sales of actual commodities that could be treated as capital transactions were sales made in compliance with a futures contract. Because under current law the gain or loss on the contract itself would have to be recognized on accrual, see I.R.C. § 1256 (1982 \& Supp. II 1984), most gains or losses on actual commodities do not receive capital treatment under current law, see id. §§ 1231-1244 (1982 \& Supp. II 1984).

Gains \& Losses from Selected Categories of Capital Assets, 1973

\begin{tabular}{|c|c|c|c|c|c|}
\hline Category & $\begin{array}{l}\text { \% of } \\
\text { Total } \\
\text { Net CG }\end{array}$ & $\begin{array}{l}\text { \% of } \\
\text { Gross } \\
\text { STCG }\end{array}$ & $\begin{array}{l}\% \text { of } \\
\text { Gross } \\
\text { STCL }\end{array}$ & $\begin{array}{l}\% \text { of } \\
\text { Gross } \\
\text { LTCG }\end{array}$ & $\begin{array}{l}\% \text { of } \\
\text { Gross } \\
\text { LTCL }\end{array}$ \\
\hline Commodities & 1.1 & 26.0 & 29.8 & 1.5 & 0.9 \\
\hline Corp. Stock & 36.0 & 32.3 & 30.8 & 25.8 & 58.9 \\
\hline $\begin{array}{l}\text { Share of pship. } \\
\text { and fiduciary }\end{array}$ & & & & & \\
\hline $\mathrm{CG}$ and $\mathrm{CL}$ & 23.5 & 9.9 & 8.9 & 7.6 & 6.6 \\
\hline $\begin{array}{l}\text { Nonbusiness } \\
\text { real prop. (othe } \\
\text { than personal }\end{array}$ & & & & & \\
\hline residences) & 22.3 & 3.2 & 0.2 & 8.3 & 1.7 \\
\hline Debt (other than & & & & & \\
\hline U.S. \& Local) & 3.5 & 0.4 & 3.8 & 0.2 & 1.5 \\
\hline Miscellaneous & 27.9 & 23.9 & 24.6 & 12.2 & 24.2 \\
\hline
\end{tabular}

The percentages of total net gain in the table are somewhat misleading, because their size depends not only on the general significance of the category among all capital transactions but also on the extent to which taxable capital transactions in that category 
and other short-term securities, would receive a matching detriment: the system would eliminate their current favorable rate of tax, ${ }^{265}$ since the system would tax all gain and loss as ordinary income. Moreover, the relative benefit of investing under the proposed system as opposed to current law is not easy to gauge. Coupled with the proposal to tax gain on accrual is a provision allowing full immediate deduction for accrued losses. Although investors tend to be optimists anyway, this provision should encourage people to undertake more risky investments in both long- and short-term debt.

There is also a transition problem in implementing the system: how would the IRS get people to catalogue all their assets in the first year this system is used? It may be possible to use data the IRS already has from tax returns and other information filed with it to create a preliminary listing of taxpayer assets. Because taxpayers currently must list dividends and interest by payor, and must list and describe certain real property investments, it might be possible for the IRS to begin the process for taxpayers by sending to them a listing of the assets of which it is aware. The taxpayer would then be required to supplement the list with all the assets that the IRS did not include.

Indeed, if an accrual system were adopted, Congress might seriously consider having the IRS generally take the first step in filling out individual tax returns. Although it would undoubtedly need a substantial initial investment, the IRS could acquire the capability of keeping track of assets that a taxpayer listed in the previous year, and then sending out lists with current year values for such assets. ${ }^{286}$ The tax-

are profitable. Since the total of gains and losses in futures transactions are roughly the same, they are only a small portion of the total of net gains on all capital transactions. In contrast, real estate, which is sold disproportionately at a profit, comprises a larger percentage of total net gains.

What is most telling in this table is the extent to which transactions in commodities futures are taxed on a short-term basis. It is particularly noteworthy that they play such a large role in tax-disfavored short-term capital gains, compared with their relatively small portion of total tax-favored long-term capital gains.

${ }^{205}$ Under I.R.C. $\S 1256(\mathrm{a})(3)$ (1982), 60\% of the gain on such contracts are deemed long-term even if the contract is not held for the long-term holding period. It is true that the provision also makes $60 \%$ of losses long-term even if the futures are held for less than the long-term holding period, and that virtually all losses on commodities were short-term under the prior tax regime. See supra note 264. From the standpoint of the investor, however, gains are presumably expected more than losses, and thus the advantage on the gain side should more than compensate for the detriment on the loss side.

${ }^{288}$ If this approach were taken, either the valuation process for this purpose would have to take place prior to the end of the year-perhaps on September 30-or tax returns would normally become due after April 15. Otherwise, there would not be enough time for the IRS to compile all the necessary data and get it to taxpayers in a timely fashion. Early valuation should create no problems as long as purchases and sales after the valuation date are not under the system in that year. The problem with 
payer would then revise the listings for those assets sold during the year. This procedure could substantially ease the administrative burden on taxpayers in complying with the system.

One additional advantage of a system in which the IRS keeps records for taxpayers in this manner is that if the IRS collected data about an individual's assets, it would become harder for people to hide their capital income. Of course, that fact could induce people to attempt to hide their assets from the IRS. The IRS would probably discover such deception, however, when it made a final accounting at the time the taxpayer's will is probated.

This procedure raises the question of whether an accrual system would entrust the IRS with too much information about taxpayers. It also raises the question of whether the move away from a pure selfassessment system is desirable. Neither question should be answered quickly. In considering them, however, one should note the extent to which Congress has recently increased filing requirements in the Code. ${ }^{287}$ This practice has inevitably led to an increase in the information that the IRS can marshall about individual taxpayers, and to a decrease in the self-assessment nature of the tax system. Perhaps it would be wise to confront both these issues directly under an accrual system rather than have the changes occur piecemeal. ${ }^{268}$ Moreover, the potential increase in compliance may raise in the minds of some the significance of the invasion of privacy inherent in the suggested system. It is just as well to consider that sooner rather than later.

purchases was discussed previously. See supra note 82. Essentially the same problems arise for sales. If sales after the valuation date could be taken into account in the year of sale, there would be planning opportunities for taxpayers, who could decide whether to sell assets that have changed in price between the valuation date and the end of the year. The result of using a September 30 date for assets on the accrual system would be a tax return encompassing two different taxable years-the calendar year for earnings and a fiscal year for asset gains and losses. Because this structure seems awkward, a delayed filing date may be preferable. In light of the structure that exists in the Code for keeping taxpayers up-to-date on their tax payments throughout the year, this method should not affect collections substantially.

${ }^{267}$ See, e.g., I.R.C. § 6041A (1982 \& West Supp. 1986) (reporting requirements for payments of remuneration of services and direct sales); $i d$. $\S 6053$ (c) (1982 \& West Supp. 1986) (reporting requirements for tips received); id. § 6050I(a) (Supp. II 1984) (reporting requirements for cash receipts of more than $\$ 10,000$ ).

${ }^{288} \mathrm{I}$ am aware of only one recent article that considers the privacy issue in the context of enforcement of the tax law. See Miller, Tax Compliance Versus Individual Privacy: A Conflict Between Social Objectives, in Income Compliance: A RePorT of the ABA Section of Taxation Invitational Conference on Income Tax COMPLIANCE 173 (1983). 


\section{SUMMARY AND CONCLUSION}

This Article has developed a specific proposal for structuring and implementing an accrual tax system. Under this proposal, gains and losses on investment assets would be taxed to individuals at ordinary income rates in the year the gains or losses accrue. Some assets-notably owner-occupied residences and inexpensive consumer items-would be excluded from the system completely. Items that are particularly difficult to value-notably closely held stock and collectibles-would be taxed only on realization, but with an adjustment to the final gain or loss that is intended to compensate for the fact that interim gains and losses were not taxed annually. The realization rules for such assets, however, would not include all the special nonrecognition rules of current law. Certain business assets-notably inventories, accounts receivable, and depreciable personal property-could be included in the system through modified versions of current law already applied to them that approximate accrual taxation. Other intangible business assets-good will and going concern value-would not be treated on an accrual basis. Business and investment liabilities would generally be incorporated in the system.

The advantages of the proposed system are numerous. The proposal could lead to an elimination of the corporate tax system and allow us to include inflation adjustments in the tax system without difficulty. The changes outlined above would enable the excision of a substantial portion of the Internal Revenue Code. Although there would be an added cost due to the need to keep track of current assets and their values for all taxpayers, the IRS can be expected to handle that work efficiently.

An accrual tax system should be seriously considered as a means of simplifying the tax law, a primary goal of tax reform. How is such a system simpler than current law? It is simpler for those who measure the complexity of the Code by its size. It is simpler for those who measure the complexity of the Code by the ambiguity of its interpretation. Valuation would be the only ambiguity introduced by the system into the streamlined Code, and most of the valuation methods suggested above are purely objective and allow for no controversy in regard to most assets. Finally, an accrual system is simpler-vastly simpler-for those who measure the complexity of the Code by the possibilities for tax-motivated business planning that it presents.

The argument that this system is not simple must come from two other measures of complexity: recordkeeping complexity, and complexity for those who confront the Code mainly through forms and instruc- 
tions. For those in the latter group-generally lower income taxpayers with few if any assets that are affected by the system-the impact of an accrual system may not be great. The extent to which they are affected depends on the extent to which recordkeeping requirements would be increased for those taxpayers who are affected by the accrual system. Given the difficulty of reconstructing basis after many years of holding an asset, which commentators documented at great length and in great detail in the controversy over carryover basis, ${ }^{269}$ a tax reformer can reasonably ask whether the system outlined above, with assistance in compliance provided by the IRS, could be any more difficult to comply with conscientiously than the current realization system. If I am correct in thinking that it would not be, we need no longer consider a consumption tax the only real alternative to our current income tax system. We should make accrual taxation the next item on our agenda for major tax reform.

${ }^{269}$ See, e.g., Estate and Gift Tax Problems Arising from the Tax Reform Act of 1976, Hearing Before the Subcomm. on Taxation and Debt Management Generally of the Senate Comm. on Finance, 95th Cong., 1st Sess. 1-318 (1977). 


\section{APPENDIX A}

\section{The Measurement of Individually Held Assets}

Data on the values of all assets held by individuals are necessarily approximate. The figures used throughout this Article are based on tables compiled by the Federal Reserve Board. ${ }^{1}$ In addition, this Article has referred to tables compiled by Raymond W. Goldsmith. ${ }^{2}$ The data in these two sources are not wholly consistent, and I discuss some of the significant differences in footnotes in the body of the Article.

The tables published by the Federal Reserve are not perfectly suited for the analysis in this Article. While the tables reflect current values of tangible assets and traded securities, they list debts-whether assets or liabilities-at their face amounts. Fortunately, recent work on debt valuation facilitates the conversion of par values to market values for many categories of debt instruments listed in the Federal Reserve tables. Eisner and Pieper have developed such adjustments for the government sector of the balance sheets. ${ }^{3}$ Strong has done the same for the nonfinancial corporate sector. ${ }^{4}$ I have based my conversions of par values in the balance sheets to market values on these earlier works. ${ }^{5}$ In

1 See Board of Governors of the Fed. Reserve Sys., Balance Sheets for THE U.S. ECONOMY, 1945-1984 (1985) [hereinafter cited as Federal Reserve BaLANCE SHEETS]. I supplemented the information in this source using various supporting tables furnished to me by Elizabeth Fogler at the Federal Reserve, copies of which are on file with the University of Pennsylvania Law Review.

2 See R. Goldsmith, The National Balance Sheet of the United States, 1953-1980 (1982).

3 See Eisner \& Pieper, A View of the Federal Debt and Budget Deficits, 74 AM. Econ. REv. 11, 12-14 (1984). The data I have used in this Article include updated material through 1984 furnished to me by Pieper. These revisions are available in $R$. Eisner, How Real is the Federal Deficit? 205 (1986).

- See J. Strong, The Market Valuation of Credit Market Debt (Nov. 1985) (review draft) (copy on file with the University of Pennsylvania Law Review). The paper includes data through 1983. I approximated the figure for 1984 by comparing the fluctuations of the rate for nonresidential mortgages that Strong provides through 1983 with the rate for residential mortgages that Eisner and Pieper furnish through 1984.

- I have converted from par to market values data from six Federal Reserve tables. See Federal Reserve Balance Sheets, supra note 1 , at $16-25$ table 702 (households-'H'); id. at 26-30 table 703 (farms-'F'); id. at 31-35 table 704 (nonfarm, noncorporate business-'NN'). These three tables are combined in the "Assets and Liabilities of Individuals" balance sheets, table 707, which is on file with the University of Pennsylvania Law Review. I have adjusted data from the tables dealing with "Life Insurance Companies' Assets and Liabilities" ('LI'), "Private Pension Funds" Assets and Liabilities" ('PP'), and "State and Local Governments Retirement Funds' Assets and Liabilities" ('FL') to correct the data on lines 29 and 30 of the household balance sheets. 
my analysis, I utilize annual conversion factors for the following seven categories of assets and liabilities: ${ }^{6}$ total U.S. debt, ${ }^{7}$ U.S. notes, ${ }^{8}$ U.S. notes and bonds (weighted average), ${ }^{9}$ state and local bonds, ${ }^{10}$ corporate bonds, ${ }^{11}$ home mortgages, ${ }^{12}$ and nonresidential mortgages. ${ }^{13}$

For purposes of this Article, the remaining imprecisions in the data should not affect the final conclusions significantly; these imprecisions should nevertheless be identified. The par-to-market conversions used are not always a perfect match for the data being adjusted. It is not always clear, for example, whether the home mortgage or the nonresidential mortgage index should be used for various categories of mortgages. Indeed, in some cases it might be appropriate to use a combination of the two mortgage indices. Still, the correct index can easily be applied to the main category that is significant for individuals-home mortgages.

Some of the data were not amenable to any of the existing conversions to market value. A particular asset of note is tax-exempt securities, listed as an obligation on the Federal Reserve's household balance sheets (line 39 of table 702). This category encompasses student loans taken out by individuals and certain obligations of nonprofit organizations, such as hospitals. Using data on new issuances of these two categories of debt, I calculate the amount of outstanding debt that could be

${ }^{6}$ The first four and the sixth factors are from Eisner \& Pieper, supra note 3, at 12-16. The seventh factor is from J. Strong, supra note 4, at 7 table 5. The fifth factor is the average price of all New York Stock Exchange listed bonds as recorded in NEw York Stock Exchange Fact Book (1985). Eisner and Pieper modify this index to exclude foreign bonds. Telephone interview with Paul J. Pieper, Assistant Professor of Economics, University of Illinois (Jan. 2, 1986). Strong modifies it to exclude debt of nonfinancial corporations. Telephone interview with John Strong, Professor of Economics, School of Business Administration, College of William and Mary (Dec. 11, 1985).

${ }^{7}$ This factor was used to convert $\mathrm{H} 20$ (that is, line 20 of the Household Balance Sheets, "Other Treasury Issues"); LI6, PP7, and SL6 (all labeled "Treasury Issues"). See Federal Reserve Balance Sheets, supra note 1.

8 This factor was used to convert H19 (Savings Bonds). See id.

- This factor was used to convert H21, LI7, PP8, and SL7 (all labeled "Agency Issues"). See id.

${ }^{10}$ This factor was used to convert H22 (State \& Local Obligations) and LI8 and SL8 (both labeled "Tax-Exempt Obligations"). See id.

11 This factor was used to convert H23 (Corporate and Foreign Bonds); F18 (U.S. Government Loans); F19 (Federal Intermediate Credit Bank Loans); LI9, PP9, and SL9 (all labeled "Corporate and Foreign Bonds"). See id.

12 This factor was used to convert H25 (Mortgages (assets)), H37 (Home Mortgages (liabilities)), H39 (Tax-exempt Securities (liabilities)), and F15 (Mortgages (liabilities)). See id.

${ }^{13}$ This factor was used to convert $\mathrm{H} 38$ (Other Mortgages (liabilities)); NN16 (Mortgages (liabilities)); LI10, PP10, and SL10 (all labeled "Mortgages" (assets)). See id. 
attributed to individuals. ${ }^{14} \mathrm{I}$ then use this figure in the tables, without further adjustment. ${ }^{15}$

An additional problem inherent in the Federal Reserve's data on "individuals" is that they include data on nonprofit organizations. Many of the assets of nonprofit organizations are identified as such on the asset side of the balance sheets; these I have removed from my totals for individuals. ${ }^{16}$ On the liability side, however, I have not been able to remove the liabilities of nonprofit organizations, except in the case of "tax-exempt securities."

I have not attempted to adjust all assets and liabilities listed on the balance sheets at par value. In the case of liabilities, I have generally assumed that consumer credit, trade credit, and miscellaneous loans are of a sufficiently short-term nature that their value is quite close to their face amount. On the asset side, I have made the same assumption regarding all bank deposits and money-market shares, although an argument could be made that large time-deposits, at least, should be adjusted.

Furthermore, I have not attempted to adjust life-insurance policy loans of individuals, though they could be discounted significantly. These loans appear as assets on the balance sheets of life insurance

14 Treasury Department data on new issuances from 1975-1984 were supplied to me by Laura Rubin of the Capital Markets Group of the Federal Reserve (copy on file with the University of Pennsylvania Law Review). It appears that prior to 1975 virtually all bond issues in this category were for the benefit of nonprofit entities rather than for student loans. To determine the level of debt outstanding, I add issuances in the current year to the prior year's level of debt and compare that figure to the balance sheets' figures for current year debt levels. The difference reflects repayments in the current year. To simplify calculations, I assume that repayments were made pro rata between the two categories of debt based on prior year levels of debt outstanding. I make no attempt to compensate for the possible differences in the age of the two categories of debt or for any differences that may exist in the maturities of the two types of debt. Adjusting for those calculated repayments, I am able to estimate the amount of tax-exempt debt attributable to individuals.

${ }_{15}$ Student loans might have been identified specially for adjustment in my calculations, since data does exist on net annual student loans made. See, e.g., BuREau of The Census, U.S. Dep't of Commerce, Statistical Abstract of The United STATES 166 table 269 ("Major Federal Student Financial Assistance Programs") (1984). Those amounts substantially exceed the amounts in the balance sheets' lines for tax-exempt loans. Because such loans are often subsidized in one way or another, a precise attempt to adjust par values to market values in the balance sheets might well account for that difference, though Eisner and Pieper apparently choose not to do so, see R. EISNER, supra note 3, at 212 . In any event, the treatment proposed for the valuation of loans, see supra text accompanying notes 71-72, would not impose a new tax on the initial benefit of a subsidized loan, but would tax only the change in value of the loans.

${ }_{16}$ I subtract from the balance sheet of individuals the data in $\mathrm{H} 5$ (Nonprofit Institutions' Residential Structures), H6 (Nonprofit Plant \& Equipment), and H10 (Nonprofit Institutions' Land). See Federal Reserve BaLAnce Sheets, supra note 1 , at $16-25$ table 702 . 
companies, and about $90 \%$ of the assets of life insurance companies are recorded on the asset side of the balance sheets of individuals as life insurance and pension reserves. Thus, for any $\$ 100$ policy loan listed as a liability on the balance sheets of individuals, there will be $\$ 90$ of assets on those same balance sheets. Accordingly, the failure to adjust life insurance policy loans has little effect on the net assets of individuals. Because owner-occupied homes receive favored treatment under the proposal in this paper, I must identify them as precisely as possible. I therefore recharacterize as owner-occupied homes any farm residential structures that are owner-occupied. ${ }^{17}$

Table 1 in the text is an adjusted balance sheet for individuals for 1984 , based on the Federal Reserve data. ${ }^{18}$ The most recent complete data from Goldsmith's study is for the year 1975. In order to compare the Federal Reserve figures with Goldsmith's figures, I present in the first column of table A-1 the comparable Federal Reserve figures for 1975, which, like Goldsmith's data on liabilities, are uncorrected for market values. To facilitate comparisons with the data in table $1, \mathrm{I}$ also include in table A-1's third column percentages for comparable categories, derived by adjusting the Federal Reserve's data for 1975.

17 The information is available through 1979 in BUREAU of ECONOMIC ANALYSIS, U.S. Dep'r of Commerce, Fixed Reproducible Tangible Wealth in the UNITED STATES, 1925-79, at 298 (1982). Data for the years 1980-84 were furnished to me by Elizabeth Fogler of the Federal Reserve (copy on file with the University of Pennsylvania Law Review). The Bureau of Economic Analysis makes no separate estimate of the owner-occupied portion of farm land; however, since the owner-occupied portion of farm land is presumably only a small portion of the value of farm land, no attempt is made to compensate for that omission.

${ }^{18}$ See table 1, supra pp. 1125-26. 
Table A-1

1975 Year-End Balance Sheet of Individuals in the U.S. with Tangible Assets at Current Cost

\begin{tabular}{|c|c|c|c|}
\hline Category & $\begin{array}{r}\text { Amount } \\
(\$ \text { million })\end{array}$ & $\begin{array}{l}\% \text { of } \\
\text { Total }\end{array}$ & $\begin{array}{l}\% \text { of Adj. } \\
1975 \text { Data }\end{array}$ \\
\hline & \multicolumn{3}{|c|}{ Assets } \\
\hline Tangible assets & $3,225,718$ & 55.3 & 54.5 \\
\hline Reproducible assets & $2,329,283$ & 39.9 & 39.1 \\
\hline Residential structures & $1,252,635$ & 21.5 & 22.0 \\
\hline Owner-occupied housing & 973,777 & 16.7 & 17.8 \\
\hline Other & 278,858 & 4.8 & 4.2 \\
\hline Nonres. plant \& equipment & 400,583 & 6.9 & 5.1 \\
\hline Inventories & 91,045 & 1.6 & 1.6 \\
\hline Consumer durables & 585,020 & 10.0 & 10.4 \\
\hline Land & 896,435 & 15.4 & 15.4 \\
\hline Residential & 376,412 & 6.4 & * \\
\hline Nonresidential & 388,047 & 6.6 & * \\
\hline Vacant & 131,976 & 2.3 & $*$ \\
\hline Total financial assets & $2,611,257$ & 44.7 & 45.5 \\
\hline Demand deposits \& currency & 189,961 & 3.3 & 3.4 \\
\hline Time \& savings accounts & 766,000 & 13.1 & 13.6 \\
\hline Money market fund shares & 3,696 & 0.1 & 0.1 \\
\hline Securities & 925,410 & 15.9 & 16.3 \\
\hline U.S. Govt. securities & 138,708 & 2.4 & 2.5 \\
\hline Savings bonds & 67,363 & 1.2 & 1.2 \\
\hline Other Treasury issues & 58,865 & 1.0 & 1.0 \\
\hline Agency issues & 12,480 & 0.2 & 0.2 \\
\hline State \& local obligations & 68,061 & 1.2 & 1.1 \\
\hline Corporate \& foreign bonds & 60,865 & 1.0 & 1.0 \\
\hline Open-market paper & 10,873 & 0.2 & 0.2 \\
\hline Corporate equities & 646,903 & 11.1 & 11.5 \\
\hline Investment co. shares & 43,034 & 0.7 & * \\
\hline Other corporate equities & 603,869 & 10.3 & * \\
\hline Private life insurance res. & 158,474 & 2.7 & 2.6 \\
\hline Private insured pension res. & 72,349 & 1.2 & \\
\hline Private nonins. pension res. & 186,593 & 3.2 & 6.9 \\
\hline Govt. insur. \& pension res. & 154,707 & $2.7)$ & \\
\hline Miscellaneous assets & 154,067 & 2.6 & 2.7 \\
\hline Total Assets & $5,836,975$ & 100.0 & 100.0 \\
\hline
\end{tabular}




\section{Table A-1}

1975 Year-End Balance Sheet of Individuals in the U.S. with Tangible Assets at Current Cost

(continued)

\begin{tabular}{lrcc}
\hline Category & $\begin{array}{r}\text { Amount } \\
\text { (\$million) }\end{array}$ & $\begin{array}{c}\text { \% of } \\
\text { Total }\end{array}$ & $\begin{array}{c}\text { \% of Adj. } \\
1975 \text { Data }\end{array}$ \\
\cline { 2 - 4 } Mtgs., owner-occ. nonfarm homes & \multicolumn{3}{c}{ Liabilities } \\
\cline { 2 - 4 } Noncorp. bus. mortgage debt & 482,914 & 8.3 & 8.5 \\
Consumer credit & 248,808 & 4.3 & 3.6 \\
Security credit & 223,175 & 3.8 & 4.0 \\
Policy loans & 12,113 & 0.2 & 0.2 \\
Other debt & 25,522 & 0.4 & 2.4 \\
$\quad$ Total Liabilities & 114,896 & 2.0 & 18.7 \\
\cline { 2 - 4 }$\quad$ Net Worth & $1,107,428$ & 19.0 & 81.3 \\
\hline
\end{tabular}

* For these items, there is no comparable category in table 1.

Goldsmith tabulates data for three sectors that are relevant to this Article: households, unincorporated farm businesses, and unincorporated nonfarm businesses. In table A-2, I aggregate Goldsmith's data for these sectors to get total asset values and percentages for individuals. 
Table A-2

Structure of Total Individual Balance Sheet, 1975

\begin{tabular}{|c|c|c|}
\hline Category & $\%$ of Total & $\begin{array}{c}\text { Amount } \\
\text { (\$billions) }\end{array}$ \\
\hline & \multicolumn{2}{|c|}{ Assets } \\
\hline Tangible Assets & 56.1 & $3,295.68$ \\
\hline Land & 15.4 & 904.50 \\
\hline Structures & 25.6 & $1,504.76$ \\
\hline Consumer durables & 9.3 & 547.08 \\
\hline Equipment & 2.0 & 116.53 \\
\hline Inventories & 3.8 & 222.81 \\
\hline Total Financial Assets & 43.9 & $2,581.18$ \\
\hline Demand deposits \& currency & 3.1 & 183.86 \\
\hline Time \& savings deposits & 13.1 & 772.68 \\
\hline U.S. Government securities & 1.6 & 95.88 \\
\hline U.S. agency securities & 0.2 & 11.28 \\
\hline State \& local government securities & 1.0 & 56.44 \\
\hline Corporate \& foreign bonds & 0.6 & 33.84 \\
\hline Corporate stock & 8.5 & 501.96 \\
\hline Mortgages & 1.2 & 67.68 \\
\hline Consumer credit & 0.2 & 12.75 \\
\hline Open market paper & 0.2 & 11.28 \\
\hline Trade credit & 0.3 & 18.12 \\
\hline Insurance \& pension reserves & 10.0 & 586.56 \\
\hline Common trust funds & 0.3 & 16.92 \\
\hline Individual trust funds & 2.5 & 146.64 \\
\hline Other financial assets & 1.1 & 65.29 \\
\hline \multirow[t]{2}{*}{ Total Assets } & 100.0 & $5,876.86$ \\
\hline & \multicolumn{2}{|c|}{ Liabilities } \\
\hline Mortgages & 10.4 & 612.33 \\
\hline Bank loans not elsewhere classified & 0.8 & 48.27 \\
\hline Other loans & 1.3 & 74.29 \\
\hline Consumer credit & 3.4 & 197.40 \\
\hline Open market paper & 0.1 & 4.03 \\
\hline Trade debt & 0.4 & 20.82 \\
\hline Other liabilities & 0.4 & 22.56 \\
\hline Total Liabilities & 16.8 & 979.70 \\
\hline Net Worth (Equity in Enterprise) & 83.2 & $4,897.16$ \\
\hline
\end{tabular}

Source: R. Goldsmith, The National Balance SheEt of the United States, 1953-1980, at 118, 149, 156 tables 48, 64, 68 (asset totals) and 120, 150, 158 tables 49, 65, 69 (balance sheets) (1982). 
One of the major advantages of Goldsmith's figures in comparison to those of the Federal Reserve is that Goldsmith separates the data for nonprofit entities from the data for households, while the Federal Reserve simply includes nonprofits in its household aggregates. Table A-3 displays Goldsmith's figures for the nonprofit sector.

\section{Table A-3}

Structure of Balance Sheet of Nonprofit Organizations, 1975

\begin{tabular}{|c|c|c|}
\hline Category & $\%$ of Total & $\begin{array}{c}\text { Amount } \\
\text { (\$billions) }\end{array}$ \\
\hline & \multicolumn{2}{|c|}{ Assets } \\
\hline Tangible Assets & 77.85 & 188.94 \\
\hline Land & 25.51 & 61.91 \\
\hline Structures & 50.37 & 122.25 \\
\hline Consumer durables & * & * \\
\hline Equipment & 1.97 & 4.78 \\
\hline Inventories & * & * \\
\hline Total Financial Assets & 22.15 & 53.76 \\
\hline Demand deposits \& currency & 0.08 & 0.19 \\
\hline Time \& Savings deposits & $*$ & $*$ \\
\hline U.S. Government securities & 0.99 & 2.40 \\
\hline U.S. agency securities & * & * \\
\hline State \& local government securities & 0.16 & 0.39 \\
\hline Corporate \& foreign bonds & 4.90 & 11.89 \\
\hline Corporate stock & 12.94 & 31.41 \\
\hline Mortgages & 0.58 & 1.41 \\
\hline Other financial assets & 2.50 & 6.07 \\
\hline \multirow[t]{2}{*}{ Total Assets } & 100.0 & 242.70 \\
\hline & \multicolumn{2}{|c|}{ Liabilities } \\
\hline Mortgages & 11.1 & 26.97 \\
\hline Bank loans not elsewhere classified & * & * \\
\hline Other loans & * & * \\
\hline Consumer credit & * & * \\
\hline Open market paper & * & * \\
\hline Trade debt & 3.3 & 8.02 \\
\hline Other liabilities & $*$ & * \\
\hline Total Liabilities & 14.4 & 34.99 \\
\hline Net Worth & 85.6 & 207.71 \\
\hline
\end{tabular}

Source: R. Goldsmith, The National Balance Sheet of the United States, 1953-1980, at 148 table 63 (1982).

* These categories are irrelevant herein. 
In addition, Goldsmith reproduces data from a study of 1962 asset holdings, which provide some useful detail regarding individual holdings, particularly in connection with owner-occupied homes and stockholdings. These data are contained in table A-4. The underlying study lists percentages only, not absolute dollar amounts.

Table A-4

Structure of Household Balance Sheet, 1962

\begin{tabular}{lc}
\hline Category & \% of Total \\
\hline & Assets \\
\cline { 2 - 2 } Own home & 27.0 \\
Other real estate & 7.5 \\
Automobile & 3.1 \\
Business or profession & 18.5 \\
Checking account & 1.9 \\
Savings account & 8.6 \\
U.S. savings bonds & 2.2 \\
Publicly traded stock & 17.7 \\
Other marketable securities & 2.1 \\
Mortgages & 1.9 \\
Business not managed by unit & 3.6 \\
Company savings plans & 0.6 \\
Miscellaneous assets & 5.3 \\
$\quad$ Total Assets & 100.0 \\
& Debts \\
Home mortgages & 12.1 \\
Other secured debt & 2.5 \\
Installment debt & 2.3 \\
Policy loans & 0.3 \\
Other debt & 1.1 \\
Total Debt & 18.3 \\
$\quad$ Net Worth & 81.7 \\
\hline
\end{tabular}

Source: R. Goldsmith, The National Balance Sheet of the United States, 1953-1980, at 137 table 57 (1982) (basic data taken from D. Projector \& G. Weiss, Survey of Financial Gharacteristics of Consumers 110, 118, 130 (1966)).

The previous tables reveal values of assets owned by individuals. But the primary concern of an accrual system is with changes in asset values. As I describe more fully in Appendix B, I have used the Federal Reserve figures to estimate gains accrued by individuals on their assets. Another way to estimate gains and losses accrued on assets is to look at data compiled by the Internal Revenue Service on gains and 
losses recognized on capital assets and reflected in individual tax returns.

The latest study of capital gains reports data from 1973 tax returns. Table A-5 summarizes the data in that study, showing the percentage of all transactions, of gross gain, and of gross loss, for each asset type given. 
Table A-5

Gains \& Losses Recognized by Individuals on Capital Assets, 1973

\begin{tabular}{|c|c|c|c|}
\hline Asset Type & $\begin{array}{l}\% \text { of } \\
\text { Trans- } \\
\text { actions }^{\mathrm{a}}\end{array}$ & $\begin{array}{l}\% \text { of } \\
\text { Gross } \\
\text { Gains } b\end{array}$ & $\begin{array}{l}\% \text { of } \\
\text { Gross } \\
\text { Losses } \\
\end{array}$ \\
\hline Corporate Stock & 53.8 & 26.1 & 51.9 \\
\hline U.S. Govt. Obligations & 2.2 & 0.0 & 0.2 \\
\hline State \& Local Govt. Obligations & 1.1 & 0.2 & 0.7 \\
\hline Other bonds, notes, debentures & 1.3 & 0.2 & 2.1 \\
\hline Capital Gain Distributions & $-{ }^{\mathrm{d}}$ & 2.4 & 0.8 \\
\hline \multicolumn{4}{|l|}{ Capital Gain or Loss from } \\
\hline Partnerships \& Fiduciaries & $-d$ & 7.7 & 7.2 \\
\hline \multicolumn{4}{|l|}{ Capital Gain Distributions } \\
\hline from Small Business Corps. & $-d$ & 0.8 & 0.0 \\
\hline Prior-Year Installment Sales & 7.0 & 9.7 & 0.0 \\
\hline Liquidation Distributions & - $^{\mathrm{d}}$ & 2.6 & 0.4 \\
\hline Personal Residences & 4.8 & 10.8 & - \\
\hline \multicolumn{4}{|l|}{ Nonbusiness Real Property } \\
\hline Except Pers. Residences & 4.2 & 8.1 & 1.3 \\
\hline Standing Timber & 0.3 & 0.4 & 0.0 \\
\hline Retirement Plan Distributions & $-^{d}$ & 1.8 & 0.0 \\
\hline Commodities and Futures & 1.4 & 2.5 & 8.2 \\
\hline Invol. Casualty Conversions & 1.0 & 0.1 & 0.3 \\
\hline Invol. Theft Conversions & 0.5 & 1.0 & 0.2 \\
\hline Cut Timber $(\$ 1231)$ & 0.0 & 0.1 & 0.0 \\
\hline \multicolumn{4}{|l|}{ Qualified Trade or Bus. Assets } \\
\hline \multicolumn{4}{|l|}{ \& Transactions not Classified } \\
\hline Elsewhere $(\S 1231)$ & 0.9 & 0.8 & 1.1 \\
\hline \multicolumn{4}{|l|}{ All Other Livestock, except } \\
\hline Poultry, including $\$ 1231$ Livestock & 4.9 & 3.2 & 0.2 \\
\hline \multicolumn{4}{|l|}{ Other Farm Land with } \\
\hline Unharvested Crop (\$1231) & 0.4 & 0.4 & 0.3 \\
\hline \multicolumn{4}{|l|}{ Invol. Conversions not Casualty } \\
\hline or Theft $(\$ 1231)$ & 0.8 & 1.2 & 0.9 \\
\hline$\S 1245$ Gains $\mathrm{e}$ & 5.7 & 3.9 & - \\
\hline$\S 1250$ Gains $^{\mathrm{f}}$ & 1.0 & 3.8 & - \\
\hline \multicolumn{4}{|l|}{$\S 1251$ Gains on Livestock, } \\
\hline \multicolumn{4}{|l|}{$\S 1251$ Gains on Farm Land with } \\
\hline Unharvested Crop & 0.0 & 0.1 & - \\
\hline All Other Farm Land ( $\$ 1252)$ & 0.1 & 0.3 & - \\
\hline Other Types of Assetsg & 11.2 & 12.7 & 24.3 \\
\hline
\end{tabular}


Where " 0.0 " appears in table, percentage was less than $0.05 \%$.

Where "-" appears in table, the entry was not applicable. But see note $d$ below.

a. The total number of transactions was $16,643,208$.

b. The total gross gain was $\$ 50,552,376,000$.

c. The total gross loss was $\$ 15,405,350$.

d. Since the IRS reported the number of "transactions" in its tables, distributions were not included in its totals. There was a total of 2,274,795 distributions (including allocations of capital gains from partnerships) reported on returns, which is $13.7 \%$ of the number of transactions reported. Their sources were as follows:

Distributions, 1973

\begin{tabular}{lc}
\hline Category & Percentage \\
\hline Capital Gain Distributions from Mutual & \\
$\quad$ Funds \& REITs & 57.5 \\
Share of Gain or Loss from & \\
Partnership or Fiduciary & 32.3 \\
Capital Gain Distributions from Small & \\
$\quad$ Business Corporations & 2.1 \\
Liquidation Distributions & 2.3 \\
Retirement Plan Distributions & 5.8 \\
\hline
\end{tabular}

Capital gain distributions from mutual funds and REITs reflect additional gain from publicly traded corporate stock and real estate transactions that is significant in determining the total mix of recognized gains. Distributions from small business corporations and the share of gain or loss from partnerships and fiduciaries reflect gains and losses from assets of unknown identity held by those entities. Liquidation distributions from corporations reflect recognized gains and losses on complete or partial liquidation of corporations. Capital gain treatment of retirement distributions (including lump sum distributions) reflects favorable treatment granted to such distributions, not a special underlying asset of the pension fund.

e. $\$ 1245$ gain is mostly gain on personal property.

f. $\quad \$ 1250$ gain is mostly gain on real property.

g. Because the category "Other Assets" includes so many assets, its definition is worth noting: "This category included mortgages, foreign currency conversions, nonbusiness bad debts, dissolved employee benefit funds, life interest in estates, cancellations of lease agreements, termination payments to employees, patents, (including patent royalties), other royalties, and other assets not readily classified elsewhere or specifically identified." INTERNAL RevEnUE SERvice, 1973, Statistics of INCOME: Sales of Capital Assets Reported on Individual InCome Tax Returns, Supplemental Report 11 (1980).

\section{APPENDIX B}

\section{The Effect of Accrual Taxation on the Tax Base and Tax RATES}

Taxing changes in the values of most assets will substantially increase the tax base, which will allow a significant reduction in tax rates. To determine the extent of the increase in the tax base, one must determine how much the values of relevant assets can be expected to 
increase. Data collected by the Federal Reserve Board and the Internal Revenue Service is useful for this purpose. The Federal Reserve's flowof-funds balance sheets ${ }^{19}$ provide data on asset holdings. Table 702 of the balance sheets reflects changes in the level of household "financial assets" (line 11), ${ }^{20}$ which includes individuals' equities in noncorporate businesses $^{21}$ and excludes homes ${ }^{22}$ and consumer durables. As explained in Appendix A, most debt is recorded by the Federal Reserve at book value and must be corrected to reflect market value. Because the proposed accrual system would tax pension savings (line 30 of table $702)^{23}$ directly, rather than attributing them to particular individuals, I identify them specially in my calculations.

Annual increases in the level of financial assets held by individuals overstate the increases in the values of assets that would be taxed under the accrual system because they include new savings. Data on savings can be found in quarterly reports of the Federal Reserve that are summarized annually in the Economic Report of the President. ${ }^{24}$ For purposes of this Article, one must subtract from any increase in the level of financial assets the total financial savings of individuals (identifying specially any savings in pension reserves). One must also reduce the increase by net investment in noncorporate business assets, less the net increase in debt other than mortgage and consumer debt. ${ }^{25} \mathrm{My}$ analysis of adjusted Federal Reserve data for the years 1961-1984 reveal that the average annual increase in asset values in that period was $4.4 \%$ (4.8\% if pension reserves are excluded). ${ }^{26}$

19 See Frderal Rfserve Bai ance Sheets, supra note 1.

20 See id. at 16 table 702 .

21 These net figures reflect results from the farm and nonfarm, noncorporate balance sheets of the Federal Reserve. See id. at 26-35 tables 703 \& 704. The underlying data in those balance sheets must be adjusted, as explained in Appendix A.

22 Vacation homes are included under owner-occupied homes. If an individual lives in one unit of a multi-family home and rents out the other units, the owner's unit is recorded as an owner-occupied dwelling and the rental units are included under noncorporate businesses. Telephone interview with Elizabcth Fogler, Flow of Funds Section, Federal Reserve Board (Dec. 3, 1985).

23 See Frideral Reserve Bal.ance SheEts, supra note 1 , at 16 table 702.

24 See, e.g., Economic RePort of the President 263 table B-26 (1985) (Savings by individuals, 1946-1984); BOARD OF Governors OF THE FED. RESERve Sys., Fi.ow of Funds Accounts, Second Quarter 1985: Annual Revisions (1985) [hereinafter cited as ANNUAL. Revisions]. For purposes of the calculations in this Appendix, the ANNUAL. REvisions figures are used in preference to the figures in the Economic: Report of The President, since the September 1985 AnNual Revisrons figures are consistent with the October 1985 Balance Sheet figures that have been used. See Federal Reserve Balance Sheets, supra note 1; R. Goldsmith, supra note 2.

25 As explained in the text, see supra text accompanying note 210 , the accrual system would exclude houses and changes in the values of home mortgages.

${ }^{26}$ For my analysis of the Federal Reserve data generally, see Appendix A. 
This average increase in asset values can be used to calculate the increase in the tax base that an accrual tax system would have produced in the years 1961-1982. ${ }^{27}$ In determining the increase in the tax base, one must take account of the amount of capital gain, net of losses, already reported on tax returns (taking into account the deduction currently granted under section 1202 of the Code $^{28}$ for certain net longterm capital gains). One must also adjust for gains reported on assets other than capital assets. These amounts are reported in publications of the Internal Revenue Service. ${ }^{29}$ An analysis of that data shows that the tax base would have been increased by $21.2 \%$ in $1961-1982(20.8 \%$ if pension reserves are excluded from the base). ${ }^{30}$

These data suggest that tax rates could be reduced by a little more than one-sixth with no loss of revenue if accrued gains were included in the tax base. Because higher-income taxpayers realize disproportionate amounts of gains in property, ${ }^{31}$ one would expect the increased tax base to be taxed disproportionately when compared to total current income. Accordingly, decreasing the tax rates by one-sixth is a conservative approach.

The Treasury's 1984 Report to the President and the President's 1985 tax reform proposals indicate that a tax system with three rates-15\%,25\%, and 35\% - could raise an acceptable amount of taxes compared to the current system as long as the tax base is correspondingly expanded. ${ }^{32}$ It has been shown that the Treasury Report's proposal is equivalent to a revenue gain from base adjustments of $\$ 56$ billion. ${ }^{33}$ The income figures that come from the Federal Reserve survey

${ }^{27}$ I could not extend the calculation beyond 1982 because data on tax collections for 1983 and 1984 are not yet available.

${ }^{28}$ See I.R.C. § 1202 (1982).

29 See, e.g., Internal Revenue Serv., U.S. Dep't of the Treasury, StatisTICS OF INCOME, 1982: INDIVIDUAL INCOME TAX RETURNS (1984).

so See id.

${ }^{31}$ For example, in 1982, total net long term capital gain in excess of net short term capital loss was $4.6 \%$ of total adjusted gross income for all taxpayers. For taxpayers with adjusted gross income in excess of $\$ 200,000$, the figure was $49.6 \%$. See id. at 44, 47 table 1.4. If gains are adjusted for inflation, the disproportion is even more dramatic. See, e.g., Feldstein \& Slemrod, Inflation and the Excess Taxation of Capital Gains on Corporate Stock, in Inflation, Tax Rates, and Capital Formation 101, 105 table 7.1 (M. Feldstein ed. 1983).

32 1 Unired States Treasury, TAX Reform for Fairness, Simplicity, and Economic Growth viii, 37-39 (1984), reprinted in 71 Stand. Fed. Tax ReP. (CCH) No. 52, at vii, 37-39 (Nov. 27, 1984) [hereinafter cited as Treasury PropoSAL] (8.5\% reduction in tax collections from individuals); The President's TaX ProPOSALS TO THE CONGRESS FOR FAIRNESS, GrowTH, AND Simplicity 3 (1985) [hereinafter cited as President's Tax Proposals] (7\% reduction).

${ }^{3 s} \mathrm{R}$. Musgrave, Getting from Here to There-Is It Worth It?, paper prepared for the Federal Reserve Bank of Boston's Conference on "The Economic Consequences of Tax Simplification" 12 (Oct. 2-4, 1985) (copy on file with University of Pennsylva- 
discussed in Part III of the text exceed federal taxable income because they disregard itemized deductions such as those for mortgage interest (which reduces tax collections by $\$ 25$ billion), consumer interest ( $\$ 15$ billion), charitable contributions ( $\$ 12$ billion), and state and local taxes ( $\$ 32$ billion), a total of $\$ 84$ billion. $^{34}$ Accordingly, one can assume that the rates suggested by the Treasury and the President, when applied to the incomes shown in the Federal Reserve study, will produce a system that does not understate tax collections when compared to current law. Reducing the rates in the Treasury's and the President's proposals by about one-sixth yields a system with three rates-12.5\%, $21 \%$ and $29 \%$. Using the income brackets from the Treasury's Report, ${ }^{35}$ one can construct the following tax rate table:

Tax Rates Under Accrual System

\begin{tabular}{|c|c|c|c|c|c|}
\hline \multicolumn{2}{|c|}{ Single Returns } & \multicolumn{2}{|c|}{ Head of Household } & \multicolumn{2}{|c|}{ Joint Returns } \\
\hline $\begin{array}{l}\text { Taxable } \\
\text { Income } \\
(\$ 000 \text { s) }\end{array}$ & Rate & $\begin{array}{l}\text { Taxable } \\
\text { Income } \\
(\$ 000 \mathrm{~s})\end{array}$ & Rate & $\begin{array}{l}\text { Taxable } \\
\text { Income } \\
\text { (\$000s) }\end{array}$ & Rate \\
\hline$<2.8$ & $0 \%$ & $<3.5$ & $0 \%$ & $<3.8$ & $0 \%$ \\
\hline $2.8-19.3$ & $12.5 \%$ & $3.5-25$ & $12.5 \%$ & $3.8-31.8$ & $12.5 \%$ \\
\hline $19.3-38.1$ & $21 \%$ & $25-48$ & $21 \%$ & $31.8-63.8$ & $21 \%$ \\
\hline$>38.1$ & $29 \%$ & $>48$ & $29 \%$ & $>63.8$ & $29 \%$ \\
\hline
\end{tabular}

The adjusted data on assets and liabilities from the Federal Reserve balance sheets can also be used to calculate the effects of adjusting the tax base for inflation. Using the GNP deflator to measure inflation, one finds that compensating for inflation would decrease the expanded base by about $21.25 \% .^{36}$

Of course, the figures above should not be taken as precise calculations of the effects on the tax base of accrual taxation or of compensating for inflation. Any major change in the tax law would have effects on the values of assets that would ideally be taken into account in calculating the consequences of the change. ${ }^{37}$ Although this observation

nia Law Review).

34 The figures on tax savings came from OfFice of MANAGEMENT and BUdget, Executive Office. of the President, Budget of the United States GovernMENT, Special Analyses, 1985, at G-38 to G-42 (Special Analysis G, table G-1) (1985).

3s See 1 Treasury Proposal, supra note 32, at xvi table S-1. The President's proposal has slightly different brackets. See President's TAX Proposals, supra note 32 , at 13.

${ }^{3 e}$ See Economic Report of The President, supra note 24, at 236 table B-3 (indicating GNP deflator).

${ }^{37}$ See, e.g., C. Ballard, D. Fullerton, J. Shoven, \& J. Whalley, A Gen- 
suggests that the changes in the tax base might not be as great as calculated, the effect of accrual taxation on tax collections is likely to be greater than the figures suggest because the affected assets are held disproportionately by high income taxpayers. ${ }^{38}$ Thus, it is reasonable to suppose that the calculations presented here and the calculations based on them in Appendix $\mathbf{C}$ provide a reasonable indication of the effects the proposed change would have on tax collections.

\section{APPENDIX C}

\section{Determining Allowable Asset Holdings for TaXPayers with Potential Liguidity Problems}

As explained in the text, this Article uses certain assumptions to determine whether taxpayers with less than $5 \%$ liquid assets would be likely to suffer serious liquidity problems. ${ }^{39}$ First, it has been assumed that taxpayers would be able to pay tax liabilities at the level of current law without liquidity problems. In Appendix B, I show that tax rates could be cut by about one-sixth under an accrual tax system. Accordingly, taxpayers can be expected to pay an additional one-fifth of the tax liability calculated by applying the reduced rates to the income reported in the survey discussed in Part III, which roughly approximates taxable income. This additional amount could be applied to pay a tax on the appreciation of their assets.

Moreover, taxpayers with large amounts of appreciating assets could be expected to allot some small portion of their incomes (determined under current law) to pay a new tax on appreciation. I have assumed, conservatively, that taxpayers with incomes below $\$ 10,000$ could pay an additional $2 \%$ of their incomes in taxes, that those with incomes from $\$ 10,000$ to $\$ 50,000$ could pay $4 \%$, and that those with incomes above $\$ 50,000$ could pay $6 \%$. Once I determine the amount that taxpayers could use to pay an additional tax on the appreciation of their assets, it becomes possible to determine the value of the illiquid assets these taxpayers could own, under different assumptions regarding appreciation, and not face liquidity problems. These assumptions have been applied to the survey data collected by the Federal Reserve.

eral Equilibrium Model for Tax Policy Evaluation 242 (1985) (suggesting the need for dynamic rather than static models for tax reform); Strnad, Taxation of Income from Capital: A Theoretical Reappraisal, 37 STAN. L. REv. 1023, 1103 (1985) ("Transactional analysis as traditionally practiced ignores these effects [on the values of particular investments] . . .").

s8 See supra note 31 .

s9 See supra text accompanying notes 229-35. 
The results are summarized in table C-1. ${ }^{40}$

To understand the mechanics a little better, consider the entry in the table for the income class $\$ 20,000-25,000$. Except in the case of taxpayers earning more than $\$ 50,000$, in which I always use actual income figures in making my calculations, I assume a single, midpoint income for all members of a class. In this case, I assume $\$ 22,500$ of income. Taxpayers filing a joint return with $\$ 22,500$ of taxable income under the reduced tax rates of Appendix B would owe $\$ 2,337.50$ of $\operatorname{tax}^{41}$ An additional one-fifth of this amount, or $\$ 467.50$, would be available for tax payments since, as explained above, that is the additional amount that would presumably have been paid under current law.

In addition, I assume that the taxpayers would be able to devote $4 \%$ of their income, or $\$ 900$, to additional tax payments. Thus, the taxpayers would have a total of $\$ 1,367.50$ available for tax payments without facing liquidity problems. This figure is equal to the additional tax on $\$ 228,360$ of assets under a $4.5 \%$ rate of appreciation. It is also the tax assuming $13 \%$ appreciation on $\$ 79,048$ of assets or assuming $25 \%$ appreciation on $\$ 41,105$ of assets.

Tables C-2, C-3, and C-4 use the results in table C-1 to determine actual liquidity problems among the respondents in the survey. In the case of respondents with more than $\$ 50,000$ of income, a separate computation has been made for each respondent to determine the precise amount of assets that they might have under this analysis.

10 In constructing this table, I use the tax tables for married taxpayers filing jointly. The large majority of respondents in the survey fall into this category. Making this assumption in all cases does not bias the results one way or another. It is true that taxpayers filing joint returns pay taxes at lower rates than others, and so could tolerate additional appreciation recorded on their tax returns with less of a tax cost than other taxpayers. On the other hand, as I have explained in this Appendix, one factor I use to determine cash available to taxpayers to pay a tax on appreciation is the amount of tax that taxpayers would have paid under current rates. Because taxpayers filing joint returns pay less tax than others at the same income level, this factor tends to reduce the amount of assets that taxpayers filing joint returns could own without liquidity problems. Consequently, for some income groups, joint filers could hold more assets than others; for other groups, they could hold less.

11 I have made no attempt to adjust the figures for such items as personal deductions. 


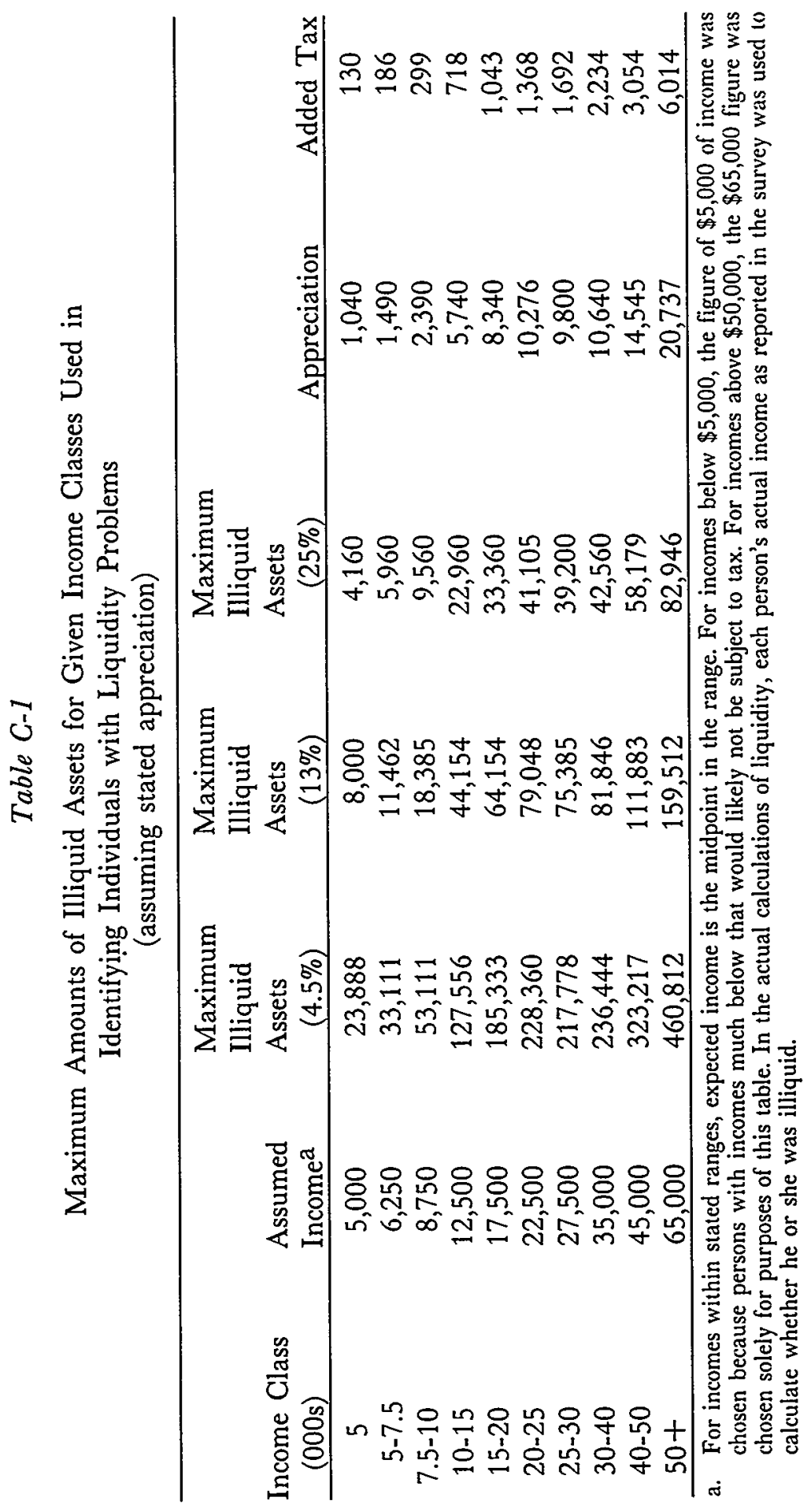




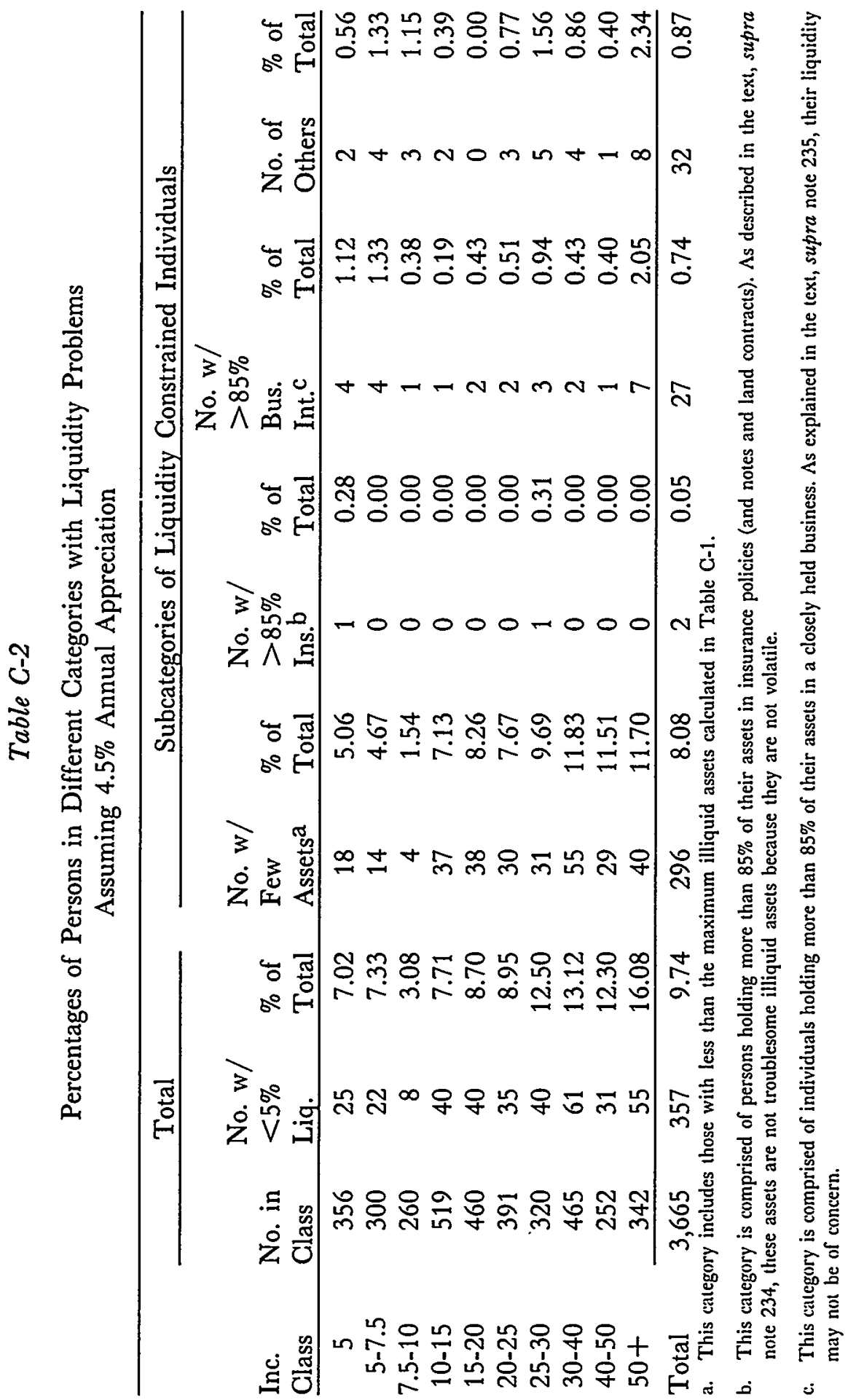




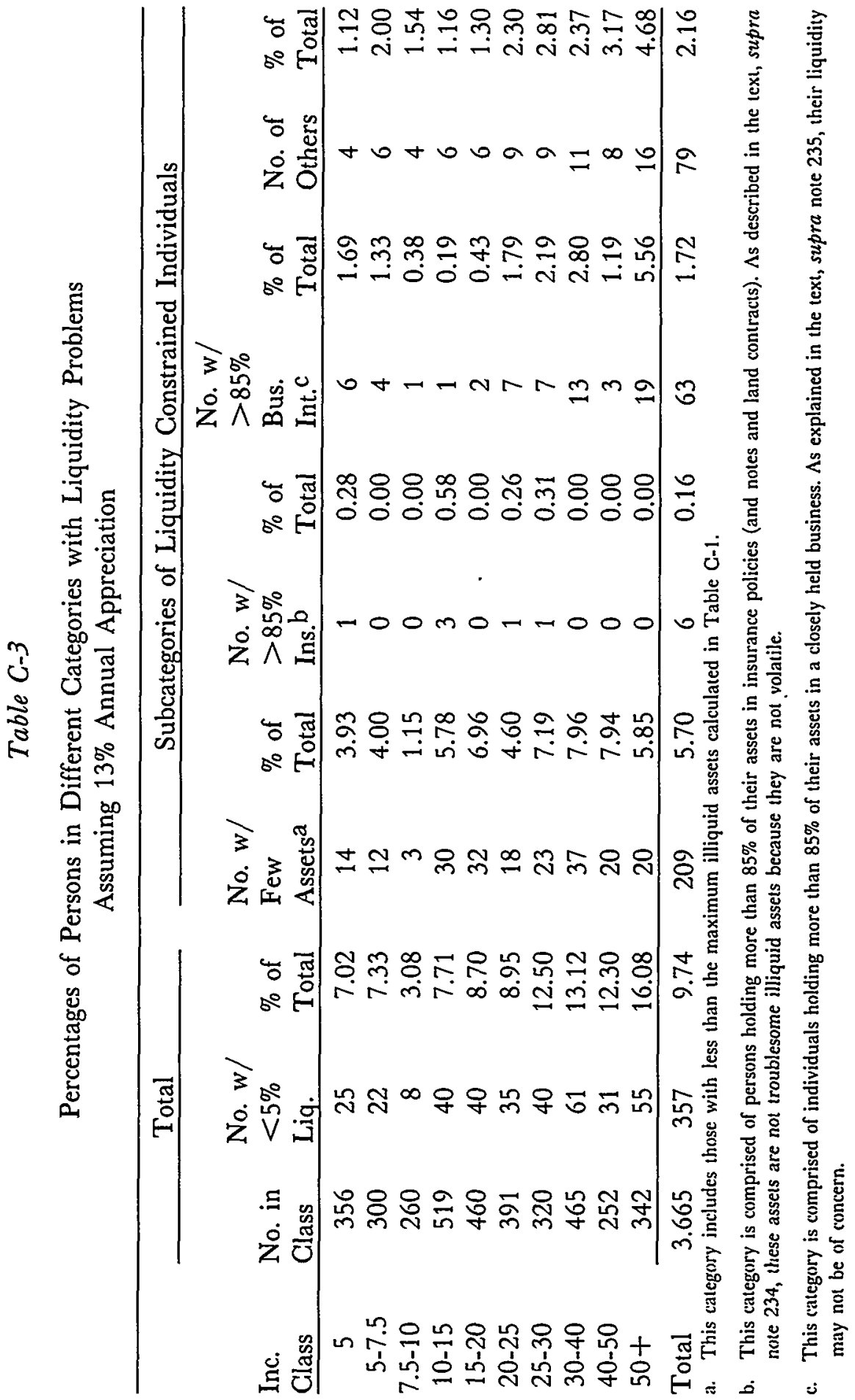




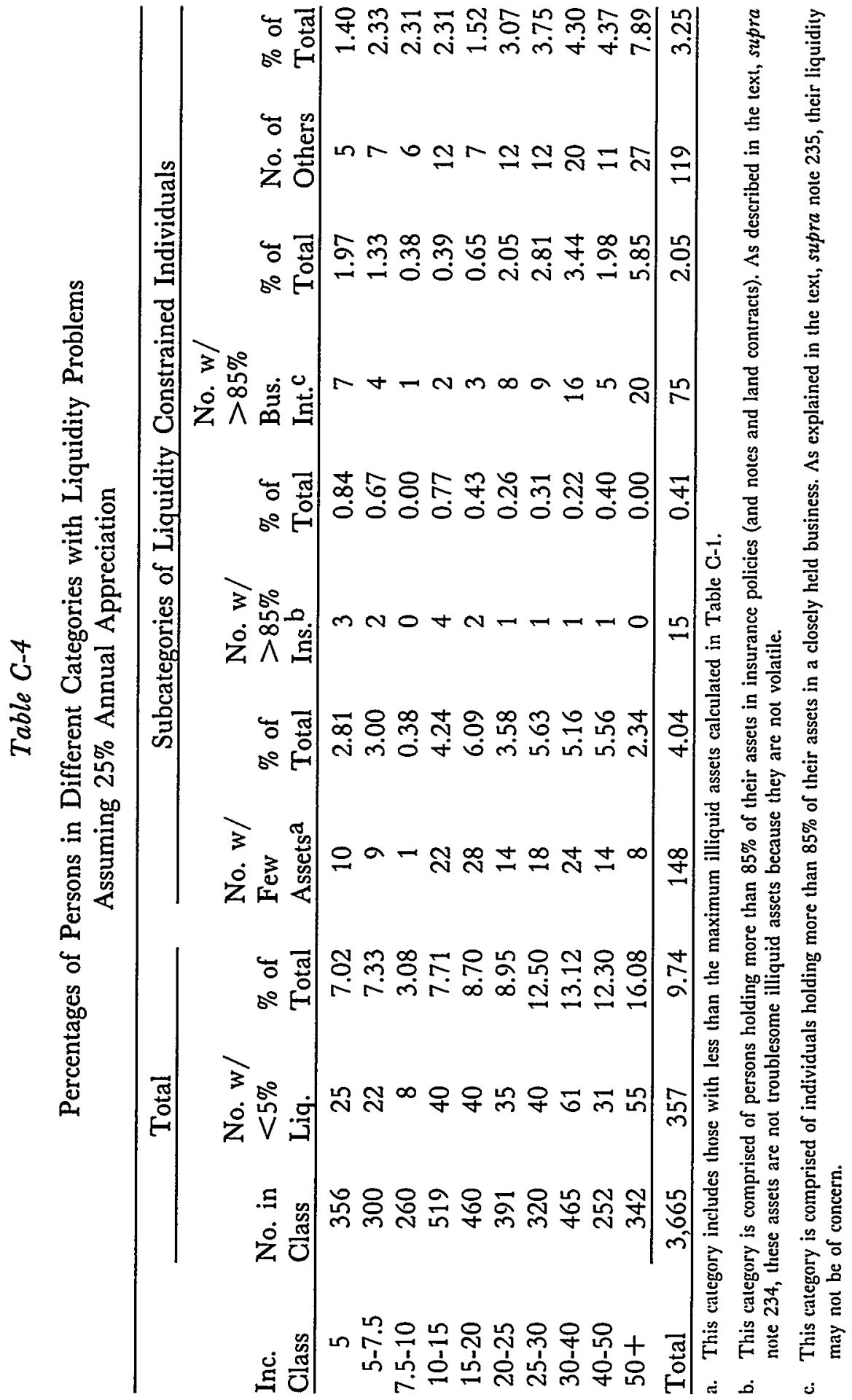


